\title{
27. PALYNOLOGY AND DINOCYST STRATIGRAPHY OF THE MIOCENE IN ODP LEG 105, HOLE 645E, BAFFIN BAY ${ }^{1}$
}

\author{
Martin J. Head, ${ }^{2}$ Geoffrey Norris, ${ }^{2}$ and Peta J. Mudie ${ }^{3}$
}

\begin{abstract}
A total of 145 samples were analyzed for palynology, and all were found to be productive. Residues are dominated by pollen, terrestrial spores, and land plant tissues. Marine palynomorphs occur in all samples, which allowed us to recognize five Miocene dinocyst assemblage zones. Dinocyst assemblages indicate cool-water conditions and suggest a neritic rather than fully oceanic environment, with not only North Atlantic and Norwegian Sea affinities, but also containing both notable protoperidiniacean and possible endemic elements. Dinocyst assemblages indicate an early Miocene age for the bottom of Hole 645E and an age no younger than early late Miocene (Sample 105-645E-24R, CC) near the top of the interval studied. These age assignments provide an estimated initiation of ice rafting in Baffin Bay at between 7.4 and $9.5 \mathrm{Ma}$. Increased terrigenous influx and apparent disappearance of certain dinocyst taxa occur in the middle to late Miocene and may be related to oceanographic changes or climatic deterioration. Spores and pollen indicate a climate that varied within a temperate regime during the early and middle to early late Miocene, followed by climatic deterioration.

Four new dinocyst species are described: Batiacasphaera gemmata, Impletosphaeridium prolatum, Operculodinium vacuolatum, and Selenopemphix brevispinosa. The acritarch genus Cyclopsiella Drugg and Loeblich is emended, and two new combinations have been created: Cyclopsiella granosa (Matsuoka) and Cyclopsiella? laevigata (Chateauneuf). Cyclopsiella granosa (Matsuoka) $\mathrm{n}$. comb. is considered a subjective junior synonym of Cyclopsiella gramulata He and Li. Ascostomocystis granulatus Chateauneuf has been provisionally allocated to Cyclopsiella and renamed Cyclopsiella? chateauneufii. Two new acritarch species are described: Cyclopsiella spiculosa and Cymatiosphaera? baffinensis.
\end{abstract}

\section{INTRODUCTION}

\section{Hole 645E}

Ocean Drilling Program (ODP) Site 645 is located at $70^{\circ} 27.48^{\prime} \mathrm{N}, 64^{\circ} 39.30^{\prime} \mathrm{W}$ in deep water $(2018.2 \mathrm{~m})$ on the western margin of Baffin Bay (Fig. 1). Hole 645E was the deepest drilled at this site and terminated at $1147 \mathrm{~m}$ below the seafloor (mbsf), penetrating an almost complete Miocene section that is possibly up to $650 \mathrm{~m}$ thick. Sediments are mainly muddy sandstones and silty mudstones that are moderately to strongly bioturbated and have a high content of terrigenous sediment. Stratigraphic control of this interval is poor owing to a paucity of calcareous and siliceous planktonic microfossils and few magnetostratigraphic tie-points. Siliceous microfossil assemblages occur rarely and are not age diagnostic. Calcareous nannofossils and planktonic foraminifers are scattered, although they provide useful age control for parts of the early and early middle Miocene. Benthic foraminifers are more abundant; however, assemblages display low diversity and are mainly agglutinated species that have poorly constrained stratigraphic ranges (see Srivastava, Arthur, et al., 1987, p. 92-101, for reports about each microfossil group). Dinocysts are the most consistently occurring marine microfossil group and are moderately to well preserved in all samples examined. Pollen and spores also are common to abundant in all samples and provide additional data to support an early to late Miocene age for Hole 645E.

\section{General Background and Objectives}

The early history of subsidence in Baffin Bay extends into the Mesozoic, and alkaline intrusions of Jurassic to Early Creta-

\footnotetext{
'Srivastava, S. P., Arthur, M., Clement, B., 1989. Proc. ODP, Sci. Results, 105: College Station, TX (Ocean Drilling Program).

2 Department of Geology, University of Toronto, Ontario M5S 3B1, Canada.

${ }^{3}$ Geological Survey of Canada, Atlantic Geoscience Centre, Dartmouth, Nova Scotia B2Y 4A2, Canada.
}

ceous age along the southern West Greenland coast are thought to be associated with incipient rifting in the area (Hinz et al., 1979; Larsen et al., 1983). Dinoflagellates as old as Campanian were reported by Costa (pers. comm., cited in Rolle, 1985) from exploratory wells drilled in the Davis Straits, and most of this area may have undergone marine transgression during the Campanian (Rolle, 1985, p. 1011). Reconstructions of plates for the North Atlantic and other geological reasoning suggest that seafloor spreading was responsible for the formation of Baffin Bay. Spreading began during the late Paleocene (magnetic anomaly 24 ) and ended in the mid-Oligocene, prior to magnetic anomaly 13 (Srivastava, 1978; Srivastava et al., 1981). Many scientists consider Baffin Bay to have widened mostly during the Eocene, allowing a greater penetration of North Atlantic waters into Baffin Bay at this time (Srivastava et al., 1981). Increased oceanic ventilation of Davis Straits sediments during the Eocene may have resulted from this period of increased oceanic circulation in Baffin Bay (Rolle, 1985).

Water depths of adjacent sills (particularly Davis Strait) probably provided important constraints on current penetration into Baffin Bay. To estimate Cenozoic water depth for Baffin Bay, Srivastava, Arthur, et al. (1987, p. 149, 150; Fig. 60) combined seismic stratigraphy with drilling results from Hole $645 \mathrm{E}$ to determine the subsidence history of Baffin Bay. A backstripping method (Watts and Steckler, 1979) was used to calculate hydrostatic and sedimentary loading effects. The estimated average paleowater depths obtained were $450 \mathrm{~m}( \pm 150 \mathrm{~m})$ for the early Oligocene $(36 \mathrm{Ma})$ and $750 \mathrm{~m}( \pm 150 \mathrm{~m})$ for the middle Miocene (16.5 Ma)-much shallower than the present water depth of $2018.2 \mathrm{~m}$ at this site. Sedimentological data for Site 645 show that oceanic circulation in Baffin Bay continued through the Neogene and that deposition during this time was frequently influenced by bottom water currents. At present, cold surface water from the Arctic Ocean flows over the site, east of Baffin Island, and is known as the Baffin Land Current. This current crosses the Davis Strait to flow south along the Labrador Shelf, where it combines with North Atlantic Water to form the Labra- 


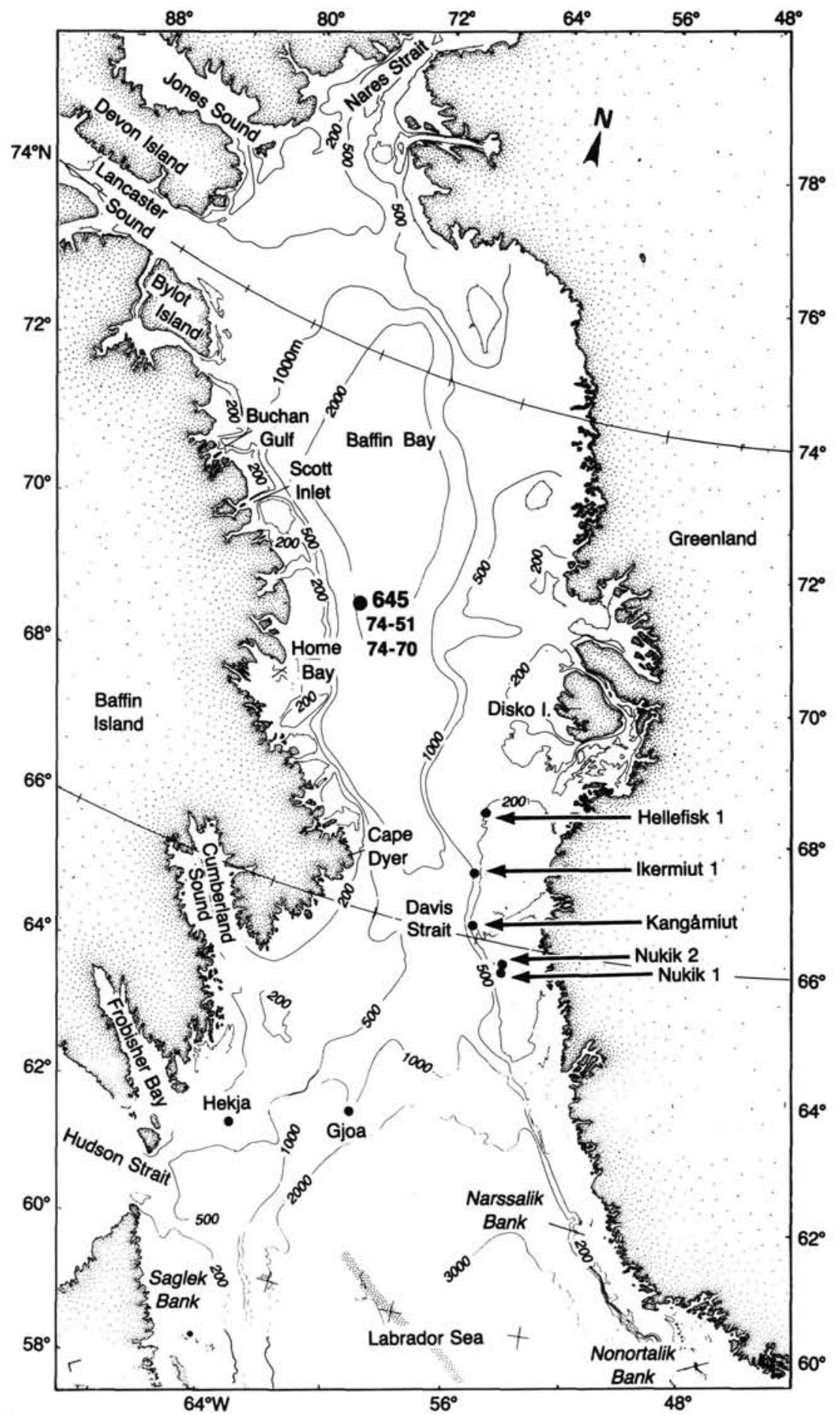

Figure 1. Bathymetric map of Baffin Bay. Location of ODP Site $645\left(70^{\circ} 27.48^{\prime} \mathrm{N}\right.$; $64^{\circ} 39.30^{\prime} \mathrm{W}$ ) is shown at a depth of $2018 \mathrm{~m}$ below sea level off the eastern shelf of Baffin Island. Also shown are the locations of exploratory wells (Hekja, Gjoa, Kangamiut, Nukik, Ikermiut, and Hellefisk). Locations of two multichannel lines, 74-51 and 74-70, shot by Petro-Canada also are indicated. Depth contours are in meters (from Srivastava, Arthur, et al., 1987. 


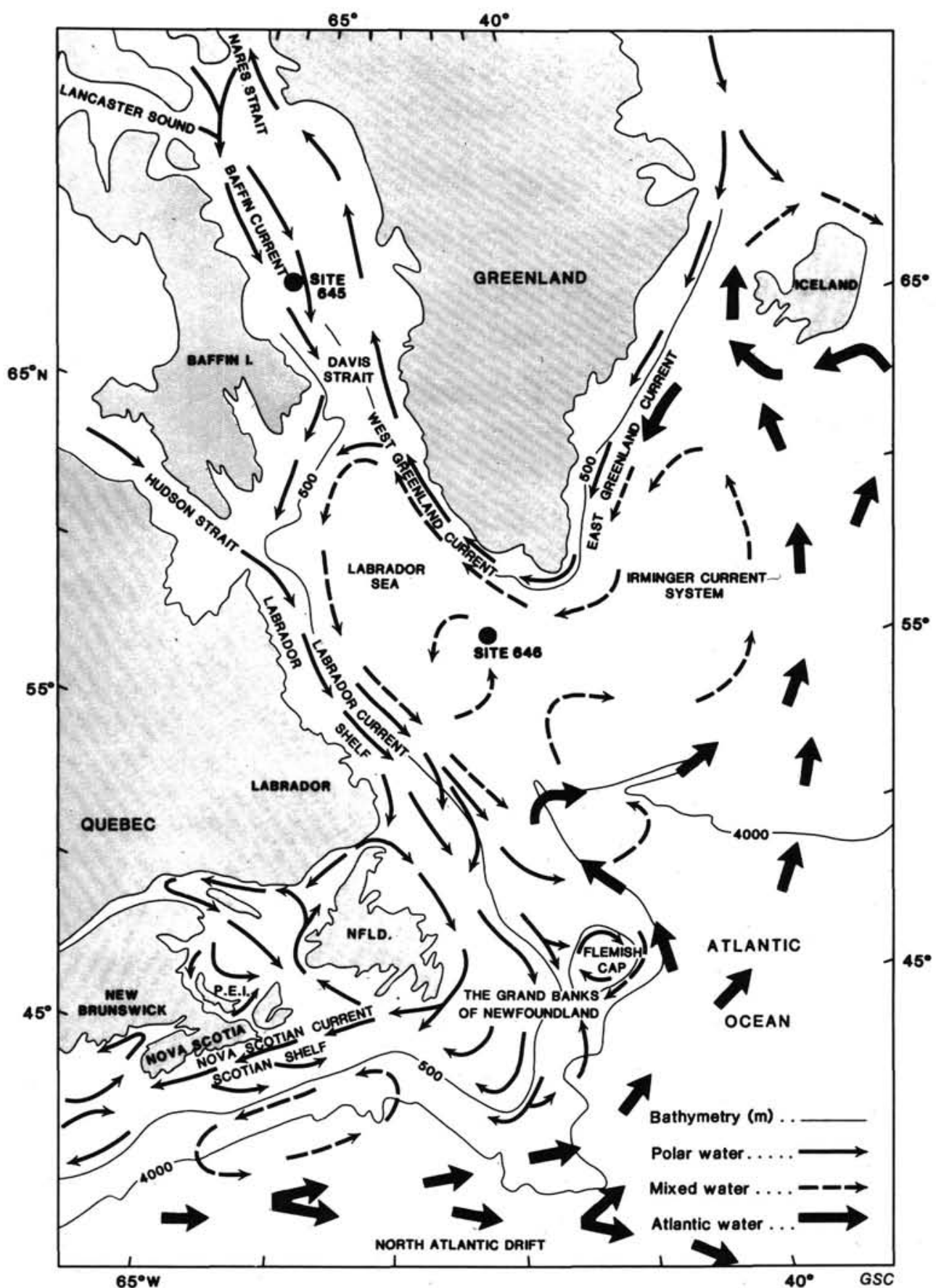

Figure 2. Modern surface current distribution in the western North Atlantic region (after Piper et al., in press), and location of ODP Leg 105, Site 645. Broad solid arrows represent warm surface currents (Atlantic water), including and contiguous with the North Atlantic Drift; narrow broken arrows represent mixed, cool-temperate surface currents; and narrow solid arrows represent cold (polar) surface currents.

dor Current (Coachman and Agaard, 1974; Aksu and Mudie, 1985; and Fig. 2). Foraminifers in Labrador Shelf wells suggest that this current existed in the Pliocene and that it developed during the Miocene (Gradstein and Srivastava, 1980). The initiation of the Baffin Land Current is an important event in the oceanographic history of Baffin Bay and may have influenced the Miocene marine biota at Site 645. The main objectives of ODP drilling in Baffin Bay as they relate to palynological work were as follows:
1. To test hypotheses concerning the nature and timing of seafloor spreading and subsidence in Baffin Bay, particularly by dating regional seismic reflectors.

2. To investigate the oceanic history of Baffin Bay, particularly with respect to its suggested role as a conduit for water exchange between the Arctic and Atlantic oceans during the $\mathrm{Ce}$ nozoic.

3. To evaluate the climatic evolution of this high-latitude site during the Cenozoic, particularly to date the onset of glacia- 
tion and to determine the nature and periodicity of glacial cycles.

This chapter describes the palynology, and particularly the dinocyst stratigraphy, of the lower part of Hole $645 \mathrm{E}$, which is of Miocene age and represents the oldest sediments drilled in Baffin Bay during Leg 105. The primary objectives of this investigation were as follows:

1. To review Miocene dinocyst literature as required by the absence of a widely accepted zonal scheme for the Arctic region, and to produce a dinocyst stratigraphy for the Miocene section of Hole 645E.

2. To provide a systematic account of the dinocyst species, allowing us to compare Baffin Bay assemblages with those of other areas.

3. To contribute to an understanding of the marine paleoenvironment of Site 645, Baffin Bay, during the Miocene, based on dinocysts and acritarchs.

4. To provide information about adjacent land vegetation and climate during the Miocene, based on terrestrial spores and pollen.

The Pliocene to Holocene palynostratigraphy of Baffin Bay (Site 645 ) is described by de Vernal and Mudie (this volume). Ages and chronostratigraphic intervals cited in this study follow the time scale of Berggren et al. (1985), as agreed by the Leg 105 Scientific Party.

Preliminary palynological results of the Miocene interval in Hole 645E have been published elsewhere (Srivastava, Arthur, et al. 1987; Head et al., 1987). These results were largely based on shipboard analyses of core-catcher samples, which were processed without the routine use of HF because of safety reasons (see Srivastava, Arthur, et al., 1987, p. 34, for shipboard processing methods). Discrepancies arising between the preliminary studies and the present shore-based investigation mainly reflect difficulties in concentrating palynomorph assemblages during shipboard processing of siliciclastic sediment.

\section{Other Miocene Palynological Studies}

A moderate number of high-latitude Miocene dinoflagellate studies have been undertaken in the last $5 \mathrm{yr}$, particularly from DSDP and ODP sites in the North Atlantic, Norwegian Sea, Labrador Sea, and Baffin Bay. Many of these sites are well dated and collectively suggest a fairly high taxonomic diversity for the Miocene. However, these studies have also revealed significant difficulties when comparing assemblages between sites. Some apparent differences will probably be resolved by more detailed study on the taxonomy and morphology of many cyst types, particularly small dinocysts and acritarchs. Other differences are probably environmental, reflecting regional paleoclimatic and paleoceanographic events within the North Atlantic. Consequently, no widely accepted zonal scheme is presently available for Miocene dinoflagellate stratigraphy, and we found it necessary to use combined data from a number of literature sources to provide the age assessments and paleoenvironmental interpretations made in this chapter. The late Miocene has been studied in the most detail and is generally well calibrated with calcareous microfossil zones. Early and early middle Miocene dinocyst stratigraphy is less well understood. This is partly caused by poor age constraint and, in some cases, by hiatuses at highlatitude sites. For example, a sedimentary break is thought to occur across the early/middle Miocene boundary at several important sections, viz DSDP Site 338, Norwegian Sea (Manum, 1976), ODP Sites 642 and 643, Norwegian Sea (Manum et al., in press) and DSDP Site 555, Rockall Plateau (Edwards, 1984a). The same problem constrains the biostratigraphic value of a
Tertiary spore-pollen zonation erected by V.E. Williams (1986) for the continental shelves of the Labrador Sea and southern Baffin Bay.

Those Miocene dinocyst studies considered useful to this study for biostratigraphic and taxonomic information are reviewed next.

\section{Denmark}

Piasecki (1980) described four dinoflagellate biozones from the Miocene Hodde and Gram formations of Denmark; in ascending order these are the Labyrinthodinium truncatum and Nematosphaeropsis aquaeducta zones (Hodde Formation), and the Achomosphaera andalousiensis and Dinopterygium verriculum zones (Gram Formation).

The Hodde Formation was dated as middle Miocene, mainly on the basis of molluscan faunas that occurred near its base. Benthic foraminifers were also reported from the Hodde Formation by Kristoffersen (1972), and King (1983) correlated these assemblages with his benthic foraminiferal zonation for the North Sea, assigning the Hodde Formation to upper Zone NSB10 and possibly part of Zone NSB11 (approximately equivalent to uppermost lower to lower middle Miocene). Piasecki (1980) accepted a middle Miocene age for both his zones (L. truncatum Zone, and superjacent $N$. aquaeducta Zone) from the Hodde Formation. The base of the L. truncatum Zone occurs about 3 $\mathrm{m}$ above the base of the Hodde Formation in the Gram boring, and Piasecki $(1980$, p. 61) suggested that the lower part of the Hodde Formation at Gram might be early Miocene in age.

Presently available data concerning Miocene dinocyst ranges support Piasecki's contention that his $N$. aquaeducta Zone is of middle Miocene age. We consider that the L. truncatum Zone may be of early Miocene age, based on the presence of Apteodinium spiridoides (= A. tectatum of Piasecki), which in a number of localities, does not occur in sediments younger than early Miocene (see "Systematic Descriptions of Marine Palynomorphs" section, this chapter). Unfortunately, a definitive global range top for $A$. spiridoides is not available, partly due to the absence of detailed palynological data across the early/middle Miocene boundary.

The boundary between the Hodde and Gram formations marks the middle/upper Miocene boundary, and Piasecki (1980, p. 61) considered the last occurrence of the dinoflagellate Systematophora placacantha and the first occurrence of $A$. andalousiensis to be indicative of the middle/upper Miocene boundary. In fact, King's (1983) interpretation of the benthic foraminifers from both the Hodde and Gram formations indicated that the equivalents to Zone NSB12 (or North Sea planktonic foraminiferal Zones NSP13 and NSP14) are missing and that a hiatus (representing part of the upper middle and lower upper Miocene) occurs between the Hodde and Gram formations, and thus between Piasecki's $N$. aquaeducta and $A$. andalousiensis zones.

The Gram Formation has been dated as upper Miocene, mainly on the basis of molluscan faunas and a planktonic foraminiferal assemblage assigned to Zones N15 and N16 (late Miocene) near the top of the Gram Formation in the Gram boring (Piasecki, 1980). King (1983) assigned the Gram Formation to the benthic foraminiferal Zone NSB13 on the basis of assemblages described by Kristoffersen (1972), thus placing the Gram Formation in the upper Miocene. Present data on dinocyst ranges give tentative support to the late Miocene age, which Piasecki proposed for his $A$. andalousiensis Zone (lower Gram Formation), on the basis of the first appearance of $A$. andalousiensis in high-latitude North Atlantic regions. This species is known to range into the middle Miocene elsewhere, although it has an acme in the late Miocene (see discussion in Head et al., a, this volume). Alternatively, Herngreen (1987) interpreted Piasecki's 
A. andalousiensis Zone as late middle Miocene age, based on a correlation with the Miocene dinoflagellate zones of Powell (1983), from northwest Italy, although this age interpretation is not supported by any of the data discussed earlier.

\section{Beaufort Sea and Canadian Arctic Islands}

Bujak and Davies (1981) and Dixon et al. (1984) described a dinocyst assemblage from the Dome Kopanoar M-13 well, Beaufort Sea, to which they assigned a late middle to late Miocene age, based on dinoflagellate evidence, although an early to middle Miocene age was indicated by the presence of foraminifer marker species. We do not recognize any evidence that precisely indicates a late middle to late Miocene age for this dinoflagellate assemblage; however, the presence of Palaeocystodinium golzowense and Systematophora ancyrea may indicate an age no younger than early late Miocene.

McNeil et al. (1982) described a low-diversity Miocene dinocyst assemblage from the Dome Gulf et al. Ukalerk C-50 well, Beaufort Sea.

Riediger et al. (1984) described a low-diversity dinocyst assemblage from the Beaufort Formation, Ellesmere Island. Their assemblage is poorly preserved, judging from their illustrations. We suspect that reworking accounts for at least some of the recorded taxa, namely Deflandrea phosphoritica (last appearance [LA] in nannofossil Zone NP25, uppermost Oligocene, Williams and Bujak, 1985; Haq et al., 1987) and Thalassiphora pelagica (LA, upper Oligocene, Head and Norris, this volume), if Riediger et al.'s suggested age of early Miocene age is correct for this assemblage.

\section{Spain}

Late Miocene dinocyst assemblages (assigned to nannofossil Zones NN10 and NN11) were described by Jan du Chêne (1977) from southern Spain. In addition to a diverse in-situ dinocyst flora, a number of dinocysts at this reference site likely were reworked from the Paleogene/Oligocene, including "Wetzeliella" spp., Thalassiphora pelagica, Chiropteridium spp., and Cordosphaeridium spp.

\section{Rockall Plateau}

Miocene dinoflagellates were first studied from the Rockall Plateau during DSDP Leg 48 by Costa and Downie (1979), and later during Leg 81 by Edwards (1984b), who provided a detailed biostratigraphy of the late middle to late Miocene. In both studies, the lower and lower middle Miocene sequences were represented by only a few samples, and in Hole 555 (Edwards, 1984a), the most completely studied section within this interval, nannofossil Zones NN4 and NN5 are missing because of an unconformity at the early/middle Miocene boundary (Backman, 1984). Note that the top four "middle" Miocene samples of Edwards (1984a) from Hole 555 (Samples 81-555-12-2, 40-44 $\mathrm{cm}$, through $81-555-16-5,50-52 \mathrm{~cm}$ ) were assigned to the Denticulopsis praedimorpha diatom Zone (Baldauf, 1984), which has been correlated with most of nannofossil Zone NN8, together with the lower part of Zone NN9 (Srivastava, Arthur, et al., 1987, Fig. 8). This correlation agrees with the nannofossil zone Backman (1984) assigned for the Hole 555 samples. Collectively, these data indicate that of Edwards' (1984a) top four "middle" Miocene samples, the two upper samples are of lower upper Miocene age, and the two lower samples are lower upper Miocene or uppermost middle Miocene in age (using Berggren et al.'s 1985 time scale).

\section{Goban Spur}

This area was studied from samples from DSDP Hole 548A by Brown and Downie (1985), who provided a detailed record of the late Miocene dinocysts and a less detailed record of a strati- graphically incomplete succession representing the early and middle Miocene (Müller, 1985, Tables 3,4; Snyder and Waters, 1985, p. 442, Fig. 3).

\section{British Southwestern Approaches}

A preliminary study of Miocene dinocysts from this area was undertaken by Powell (1988a), who compared his age determinations from dinocysts with those based on planktonic foraminifers (Evans and Hughes, 1984).

\section{Gardar Drift}

Mudie (1987) described a detailed and continuous late Miocene succession of dinocysts for DSDP Site 611 (located on the Gardar Drift) from nannofossil Zones NN9? and above (Takayama and Sato, 1987) and from the late Miocene nannofossil Zone NN11 and above of DSDP Site 607 (central North Atlantic). From high-latitude Site 611 sediments, a dinocyst zonation was proposed that could be correlated with other high-latitude zonations from the Bering (Bujak, 1984) and Norwegian (Mudie, in press) seas.

\section{Norwegian Sea}

Manum (1976) reported early and middle Miocene dinocyst assemblages from DSDP Leg 38 that were most completely represented at Site 338. A detailed dinocyst stratigraphy was given for the early Miocene of Site 338, with the middle Miocene represented by two samples. Unfortunately, calcareous microfossil control was not available for the Miocene at this site, and on the basis of diatom biostratigraphy, a short hiatus was indicated between the lower and middle Miocene (Schrader and Fenner, 1976). From ODP Leg 104 sites in the Norwegian Sea, further dinocyst studies were conducted by Mudie (in Eldholm, Thiede, et al., 1987), Manum et al. (in press), and Mudie (in press). Manum et al. (in press) divided the Miocene of ODP Site 643 into seven dinocyst zones, in ascending order as follows: Ascostomocystis granosa Zone, Evittosphaerula paratabulata Zone, Impagidinium patulum Zone, Emslandia spiridoides Zone (all of early Miocene age); L. truncatum Zone and Impagidinium aquaeductum Zone (both assigned to the middle Miocene); and the $A$. andalousiensis Zone (assigned to the late Miocene). These zones are not always well constrained by other microfossils, although the early Miocene interval may be fairly complete and contains nannofossils of Zones NN4 through NN6 age near its top. However, the middle Miocene is incomplete and bounded by unconformities. Middle and late Miocene dinocyst assemblages for Sites 642 and 643 were also described by Mudie (in press), with good biostratigraphic and magnetostratigraphic control available for the upper Miocene.

\section{Offshore Eastern Canada}

Palynological analyses of Scotian Shelf and Grand Banks wells allowed Williams (1975) and Williams and Bujak (1977b) to recognize three dinocyst zones that were provisionally dated palynologically as early, middle, and late Miocene. From wells drilled on the Labrador Shelf, Williams and Bujak (1977b) divided the Miocene into two palynological zones: one of early Miocene age and the other provisionally dated as middle to late Miocene. Additional preliminary data on dinocysts, pollen, and spores from offshore eastern Canadian wells were given in Barss et al. (1979), and a statistical biostratigraphic model using both foraminiferal and dinocyst data sets was produced by D'Iorio (1986). In all of these continental shelf studies, reworking and low recovery of dinocyst assemblages prevented these scientists from delineating late Miocene and Pliocene dinocyst assemblage zones clearly. Therefore, pollen and spores were used for additional characterization of Neogene assemblages (Barss et al., 1979), and V.E. Williams (1986) used pollen and spores to 


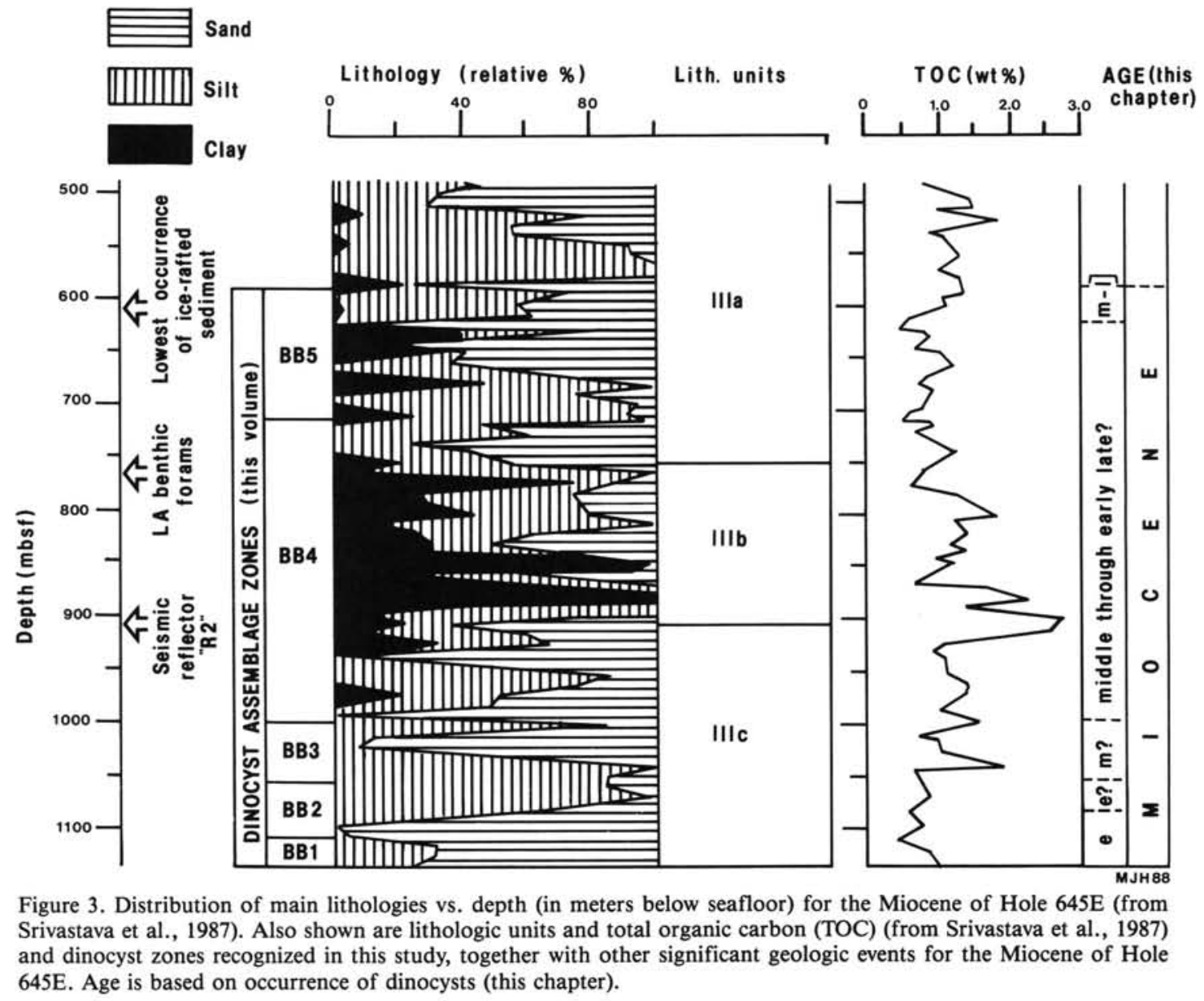

divide the Miocene into a lower Miocene Fagus granulata Zone and an upper Miocene Tsuga igniculus Zone. The late Miocene palynology of ODP Site 646, Labrador Sea, was studied by Head et al., (a,b, this volume), who described four dinocyst assemblage zones from this deep-water site.

\section{Other Areas}

Miocene dinocyst studies were also undertaken from Italy (Habib, 1971; Powell, 1986a, 1986b, 1986c; Corradini and Biffi, 1988), the Mediterranean Sea (Corradini, 1978); the Nile Delta (El-Beialy, 1988a,1988b); the Panonian Basin (Baltes, 1967, 1969); Bay of Biscay (Harland, 1979); central North Atlantic (Mudie, 1987); northwest Europe (Gerlach, 1961; Benedek, 1980; Sarjeant, 1983, 1984; Herngreen, 1987; Londeix and Jan du Chêne, 1988); offshore eastern U.S. and the Gulf of Mexico (Stover, 1977; LeNoir and Hart, 1986; Duffield and Stein, 1986; Wrenn and Kokinos, 1986); onshore eastern U.S. (Gibson et al., 1980; Edwards, 1986); eastern North Pacific (Ballog and Malloy, 1981; Fournier, 1982; Jarvis and Tocher, 1985); North Sea (Ioakim, 1979; Costa, 1980); and western and northern Pacific, including Japan and the Bering Sea (Shimakura et al., 1971; Matsuoka, 1974, 1983; Bujak, 1984; Bujak and Matsuoka, 1986a, 1986b; Matsuoka et al., 1987; Matsuoka and Bujak, 1988); and Korea (Yun, 1988).

\section{Lithostratigraphy and Seismic Stratigraphy for Hole 645E}

The stratigraphic sequence at Site 645 (Fig. 3) is a predominantly terrigenous sediment succession of poorly sorted muddy sandstones and silty mudstones (Srivastava, Arthur, et al., 1987, p. 63, 87). The interval of Hole $645 \mathrm{E}$ studied here is entirely within lithologic Unit III, which is divided downhole into Subunits IIIA, IIIB, and IIIC (Srivastava, Arthur, et al., 1987, p. 73-87). Subunit IIIA is homogeneous and consists of poorly sorted muddy sands and silty muds, with slight lamination. Pebbles of probable ice-rafted origin occur in the upper part of the subunit, with the lowest occurring in Core 105-645E-19R (about 605 mbsf). Subunit IIIB has a finer maximum grain size than Subunit IIIA and consists of silty mudstones, carbonate-rich silty claystones, and muddy sandstones, with extensive burrowing in the upper part of the subunit. Silty claystones of the lower part have distinct laminations. Organic carbon content is high (up to $3 \%$ ), with abundant wood fragments. Sediments are interpreted to have been deposited from bottom currents and periodic downslope flows of mud turbidites from the Baffin Island shelf edge (Srivastava, Arthur, et al., 1987, p. 91).

Subunit IIIC is coarser-grained than Subunit IIIB and consists mainly of muddy sandstones having pervasive bioturbation and increasing abundances of glauconite toward the base. Bottom waters were well oxygenated, as indicated by the presence of burrows and benthic foraminifers. These coarser sediments are interpreted as having been deposited beneath geostrophic bottom currents having a greater velocity than those active during the deposition of Subunit IIIB.

Seismic stratigraphy places the interval studied here within seismic Units 2 and 3, which are separated by reflector R2 at about 912 mbsf. This seismic reflector marks a regional unconformity and corresponds closely to the lithostratigraphic Subunit IIIB/IIIC boundary (Srivastava, Arthur, et al., 1987, p. 131-143). 


\section{METHODS}

Samples were first examined for any adherent drilling cake, which was then removed. Cleaned samples of about 15 to $25 \mathrm{~g}$ dry weight were prepared using the method outlined in Head et al. (a, this volume), except that residues were not oxidized and were ultrasonified for 30 to $45 \mathrm{~s}$ before sieving. Most residues were dominated by partially degraded vascular plant tissue ("woody tissues"), and ultrasonification was highly effective in dispersing much of this, causing no noticeable damage to palynomorphs. However, the palynomorph component of most samples was still greatly diluted by woody tissues even after this treatment.

A total of 145 samples was processed, and one microscope slide (coverslip dimensions, $50 \times 22 \mathrm{~mm}$ ) of each was scanned for palynomorphs using low magnification light microscopy with bright field illumination. Determinations of species and morphologic descriptions were principally accomplished using high-magnification (X1250) light microscopy, with interference contrast and bright field illumination. A few samples from each lithofacies were scanned using fluorescence microscopy, to distinguish among reworked and in-situ pollen grains. Particular emphasis was placed on the search for dinocysts and acritarchs. Forty-five preparations were studied in detail (by M. J. Head), and these are the main basis for the data described in this study. Stratigraphic occurrence of dinocysts and acritarchs and visual estimates of the relative abundance of taxa are given in Tables $2 \mathrm{~A}$ and $2 \mathrm{~B}$.

England Finder coordinates are given for the location of all illustrated specimens, and in both the plate captions and text, these are preceded by the slide number shown in parentheses, which in turn is preceded by the sample number. Dimensions of figured specimens are also given in the plate captions. Transmitted light photographs were taken with a Leitz Dialux microscope fitted with a Leitz Vario-orthomat 2 photo attachment and using Ilford Pan-F film. Stratigraphic data were tabulated using the Microsoft Excel spreadsheet program on an Apple Macintosh Plus personal computer.

\section{RESULTS OF HOLE 645E}

All samples produced dinocysts and other palynomorphs, and the processing method used by M. J. Head yielded residues in which specimens were clean of any adherent debris. However, many residues were greatly diluted by woody tissues so that rarely occurring species may not have been detected in these samples. Dinocyst preservation is moderate to good in all samples. Total pollen and terrestrial spores are considerably more abundant than marine palynomorphs; however, about one-third of the terrestrial sporomorphs may be reworked. The ratio of apparently contemporary terrestrial sporomorphs and marine sporomorphs is about 1.0 for lithologic Subunits IIIB and IIIC, increasing to about 1.5 for Subunit IIIA.

\section{Reworking}

Reworked dinoflagellate cysts are present in low numbers in most samples analyzed. Paleogene taxa (including Apectodinium, Wetzeliella, Glaphyrocysta and Areosphaeridium spp.) occurred persistently. Apectodinium augustum (Harland) Lentin and Williams, which occurred in Sample 105-645E-40R-4, $28-33 \mathrm{~cm}$, sporadically to the base of Hole $645 \mathrm{E}$, is a marker for the top Paleocene. This species has been reported previously from the North Sea (Harland, 1979); northwest Europe (HeilmannClausen, 1982, 1985; Nielsen et al., 1986; Powell, 1988b); Rockall Plateau? (Costa and Downie, 1979; Brown and Downie, 1984); and Spitsbergen (Manum and Throndsen, 1986; Head, 1988). Its occurrence at this site considerably extends its known geographic range, and may indicate the incursion of northern North Atlantic or Norwegian-Greenland Sea water masses into Baffin Bay during the latest Paleocene. Mesozoic dinocysts, particularly Cretaceous taxa (Muderongia, Deflandreoid spp., Chlamydophorella, Cyclonephelium) were also recognized in low numbers throughout Hole 645E and were recorded less persistently than Paleogene taxa. Morphologically distinctive preCretaceous spores and pollen were recorded only sporadically. Since boreal Late Cretaceous and Tertiary spore/pollen assem- blages are frequently dominated by stratigraphically long-ranging taxa (particularly certain bisaccate pollen and pteridophyte spores), it was difficult to assess the degree of reworking of these components except by differential preservation (flattening, in particular) and by fluorescence microscopy, which was not available for routine use in this study. On the basis mainly of preservation, supplemented by fluorescence microscopy of samples at stratigraphic boundaries, a small-to-moderate proportion (about $10 \%-50 \%$ ) of the spore/pollen assemblages have been reworked from Paleogene to Late Cretaceous strata.

\section{DINOCYST STRATIGRAPHY AND AGE}

Combined data from Leg 105 studies indicates that the sediments reported here for Hole 645E have an age of early Miocene to middle or early late Miocene. A continuous record is present, except for an unconformity in the upper part of the sequence (within assemblage Zone BB4), where a small part of the middle or lowest upper Miocene is presumed missing.

Approximately 102 taxa of dinocysts and acritarchs have been recorded in this study (Table 1), almost one-half of which are not identifiable with previously recorded species. Many of those that are identifiable have stratigraphic ranges extending through the Miocene. The biostratigraphic age determinations given below are thus based on a small number of species, and a formal biozonal scheme was not attempted for this initial report on the Miocene palynology of Site 645 .

Five provisional dinocyst assemblage zones are proposed (see Fig. 3 and Tables 2A and 2B) and are defined below in ascending order, starting at the base of Hole 645E. Ages for the zones are justified on dinocyst evidence alone, although they are compared with biostratigraphic determinations from other microfossil groups and magnetostratigraphy where available. Details of marine palynomorph taxonomy and previously reported ranges are given in the "Systematic Descriptions of Marine Palynomorphs" section (this chapter).

\section{Dinocyst Assemblage Zone BB1}

Samples 105-645E-78R, CC to -76R-2, 134-137 cm; depth: 1147.11121.6 mbsf; age: early Miocene.

The top of this zone is defined by the last appearance (LA) of Batiacasphaera sp. cf. B. baculata. The base is tentatively defined as the first appearance (FA) of B. gemmata n. sp.

\section{Discussion of Dinocyst Assemblage Zone BB1}

Few clearly diagnostic species occur in this zone, although Batiacasphaera $\mathrm{sp}$. cf. $B$. baculata may be similar to the $B$. $b a$ culata of Manum et al. (in press), which is restricted to the early Miocene of the Norwegian Sea, where it occurs most commonly in the lower one-half of the lower Miocene section of Manum et al. (in press).

The absence of Chiropteridium species from this and succeeding zones is considered stratigraphically significant. Chiropteridium species are a typical component of upper Oligocene sediments in many areas; for example, offshore eastern Canada (Williams and Bujak, 1977b; Barss et al., 1979); North Sea (Costa, 1980); North Pacific (Bujak, 1984); offshore eastern U.S. (Stover, 1977); eastern U.S. (Edwards, 1984a, 1986); northwest Italy (Powell, 1986a, 1986b); Germany (e.g., Gocht, 1960; Benedek, 1972); Labrador Sea (Head and Norris, this volume); and Norwegian Sea (Manum et al., in press).

In some areas this genus ranges into the lower Miocene (Williams and Bujak, 1977b; Stover, 1977; Edwards, 1986; Ioakim, 1979; possibly reworked specimens in Powell, 1986a). One species, $C$. mespilanum $(=C$. dispersum) was recorded in planktonic foraminiferal Zone N5 (approximately middle early Miocene) in offshore eastern U.S. (Stover, 1977), although a range 
Table 1. Alphabetical index of marine palynomorph species recorded in this study of the Miocene of Hole 645E. ${ }^{1}$

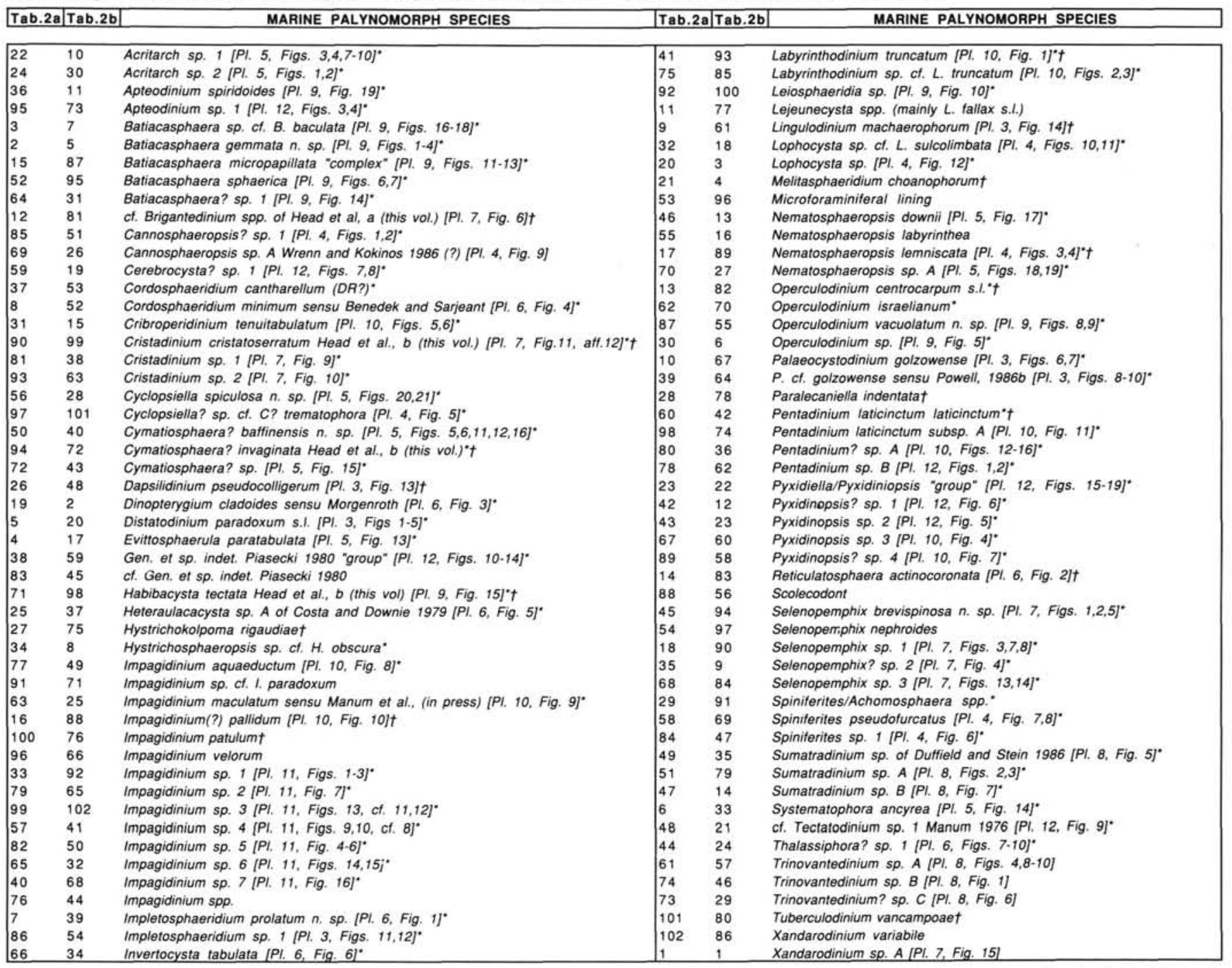

Note: Species are referenced as to their location in Table 2A (arranged by lowest occurrences) and Table 2B (arranged by highest occurrences), and in the plates (where applicable). An asterisk $\left({ }^{*}\right)$ denotes taxa discussed in the "Systematic Descriptions of Marine Palynomorphs" section (this chapter) and a dagger ( $\dagger$ ) denotes taxa discussed in Head et al. (a, this volume).

top within nannofossil Zone NN1 was proposed for this species by Haq et al. (1987) and Williams and Bujak (1985). Other species of Chiropteridium may have slightly lower range tops within the upper Oligocene, such as that of C. lobospinosum, which both Haq et al. (1987) and Williams and Bujak (1985) placed at the Oligocene/Miocene boundary. Later occurrences for this genus (e.g., late Miocene of Spain; Jan du Chêne, 1977) may be due to reworking or poor age control.

Note that Chiropteridium species were not recorded from Oligocene sediments of the West Florida Carbonate Platform, Gulf of Mexico (Wrenn and Satchell, 1988; Wrenn, pers. comm. to M.J.H., 1988), presumably as a result of environmental conditions, which likewise may have been unfavorable for the establishment of Chiropteridium species in Baffin Bay. Alternatively, their absence from sediments in Hole 645E, Baffin Bay, indicates that these sediments are not older than earliest Miocene.

\section{Other Chronostratigraphic Data for Zone BB1}

No available magnetostratigraphy exists; thus, we consider that dinocysts provide the main biostratigraphic control for this zone. However, possible additional support for an early Mio- cene age is provided by the presence of the pollen taxa Fagus granulata and Tsuga viridifluminipites, which have their LAs in Sample 105-645E-76R-2, 48-52 cm. According to V. E. Williams (1986), the disappearance of these species possibly marks the boundary between the early and middle Miocene in Labrador Sea wells.

\section{Chronostratigraphic Summary for Zone BB1}

The absence of Chiropteridium species from this and succeeding zones of this study may be evidence for a post-earliest Miocene age, while the presence of $B$. sp. cf. $B$. baculata may allow us to correlate with the Ascostomocystis granosa and Evittosphaerula paratabulata zones (early Miocene) of the Norwegian Sea (Manum et al., in press).

\section{Dinocyst Assemblage Zone BB2}

Samples 105-645E-75R-4, 15-18 cm, to -69R, CC; depth: 1114.01061.9 mbsf; age: early Miocene and early? Miocene.

The base of this zone is defined by the LA of Batiacasphaera sp. cf. $B$. baculata and the top is defined by the base of Zone $\mathrm{BB} 3$, which is indicated by the lowest persistent occurrence of 
Labyrinthodinium truncatum. Notable species restricted to this zone are Apteodinium spiridoides, and Nematosphaeropsis downii. Notable species first appearing within this zone are Labyrinthodinium truncatum (occurring rarely), "Gen. et sp. indet., of Piasecki, 1980" group, Thalassiphora? sp. 1, Selenopemphix brevispinosa n. sp., cf. Tectatodinium sp. 1 of Manum, 1976, Cymatiosphaera? baffinensis n. sp., Cyclopsiella spiculosa n. sp., and Trinovantedinium sp. A. Notable species last occurring within this zone include Cribroperidinium tenuitabulatum, Evittosphaerula paratabulata, and Lophocysta sp. cf. L. sulcolimbata.

\section{Discussion of Dinocyst Assemblage Zone BB2}

A. spiridoides has a known range of late Eocene to late early Miocene, while Nematosphaeropsis downii is presently thought to be restricted to the early Miocene. Gen. et sp. indet. of Piasecki, 1980 has been reported from the early middle Miocene to early late Miocene. Its first occurrence in Sample 645E-75R-4, $15-18 \mathrm{~cm}$, extends the range of this taxon into the early Miocene. Selenopemphix brevispinosa $\mathrm{n}$. $\mathrm{sp}$. is known from the middle and possibly late Miocene (see "Systematic Descriptions of Marine Palynomorphs" section, this chapter).

Tectatodinium sp. of Manum, 1976 has been recorded from the Eocene to middle Miocene of the Norwegian Sea area (see "Systematic Descriptions of Marine Palynomorphs" section, this chapter). Comparable specimens recorded from Site 645 are assigned to cf. Tectatodinium sp. of Manum, 1976. Cyclopsiella spiculosa $\mathrm{n}$. sp. has not previously been recorded in the literature to our knowledge, but may be closely allied with Cyclopsiella granulata $\mathrm{He}$ and $\mathrm{Li}$, which in the western Pacific has a range of late early Miocene to early late Miocene (as Ascostomocystis granosa Matsuoka, 1983 in Matsuoka, 1983; Bujak and Matsuoka, 1986a), early to middle Miocene of DSDP Site 338, Norwegian Sea (as Ascostomocystis sp. 1, in Manum, 1976) and early to early? late Miocene of ODP Site 643, Norwegian Sea (as Ascostomocystis granosa in Manum et al., in press). C. tenuitabulatum has a known range of Oligocene to early middle Miocene (e.g., Duffield and Stein, 1986, planktonic foraminiferal Zone N10; see also "Systematic Descriptions of Marine Palynomorphs" section, this chapter), and it has an LA in the A. spiridoides Zone (late? early Miocene) of the Norwegian Sea (Manum et al., in press). Evittosphaerula paratabulata was recorded rarely (no more than one specimen per slide) in this study. This species occurs in lower Oligocene to middle Miocene sediments in DSDP Hole 338, Norwegian Sea (Manum, 1976; 1979) and is restricted to a short interval within the early Miocene of ODP Site 643, Norwegian Sea (Manum et al., in press). $E$. paratabulata has also been recorded from Miocene sediments of the Beaufort Sea (Bujak and Davies, 1981; Bujak and Davies, in Dixon et al., 1984). L. sulcolimbata is so far known only from the Norwegian Sea region (Manum, 1976, 1979; Manum et al., in press), occurring in the lower Miocene (and rarely in the early late Miocene). Specimens referred in this study to Lophocysta sp. cf. L. sulcolimbata differ only in detail from $L$. sulcolimbata (see "Systematic Descriptions of Marine Palynomorphs" section, this chapter), and the two taxa are probably closely allied, if not conspecific.

\section{Other Chronostratigraphic Data}

The calcareous nannofossil Helicosphaera ampliaperta occurs in Samples 105-645E-70R-5, 61-63 cm, to -71R-3, 39-41 $\mathrm{cm}$, and suggests a zonal assignment equivalent to the "Interval with $H$. ampliaperta" of Müller (1976) and correlative with Zones NN2 through NN4 (Knüttel et al., this volume). The LA of $H$. ampliaperta has been taken to define the NN4/NN5 boundary (Martini, 1971) and its last occurrence in Hole 645E suggests that the NN4/NN5 boundary (equated with the early/ middle Miocene boundary in Berggren et al., 1985) occurs between Samples 105-645E-70R-5, 61-63 cm, and -70R-2, 42-44 $\mathrm{cm}$, (Srivastava et al., 1987). This places the early/middle Miocene nannofossil zone boundary at 1068.5 to $1063.8 \mathrm{mbsf}$, which is approximately 2 to $20 \mathrm{~m}$ lower than that tentatively defined by dinocysts (at 1061.9 to $1048.3 \mathrm{mbsf}$ ).

\section{Chronostratigraphic Summary for Zone BB2}

Dinoflagellates in this zone suggest an early to early middle Miocene age, with the LA of $A$. spiridoides (Oligocene to early Miocene) in Sample 105-645E-74R, CC a good indicator of early Miocene or older age. The presence of $N$. downii in Sample 105-645E-73R, CC also suggests an early Miocene age as does the last occurrence of $C$. tenuitabulatum in Sample 105645E-73R-4, 48-52 cm (compared with its last occurrence in the Norwegian Sea). An early Miocene or older age for these samples is supported by evidence of nannofossils at Site 645. The early/middle Miocene boundary cannot be drawn conclusively using dinoflagellate markers because of the absence of stratigraphically useful species between Sample 105-645E-74R, CC (LA of $A$. spiridoides) and Sample 105-645E-62R-1, 138-141 $\mathrm{cm}$ (FA of Impagidinium aquaeductum). However, this boundary may be tentatively placed at the top of assemblage Zone BB2, which marks the first persistent occurrence of Labyrinthodinium truncatum since this species has been reported from several early middle Miocene sites elsewhere. However, nannofossil data can be used to place this boundary somewhat lower, which places the two uppermost samples of assemblage Zone BB2 above the early/middle Miocene boundary.

\section{Dinocyst Assemblage Zone BB3}

Samples $105-645 \mathrm{E}-68 \mathrm{R}-4,117-121 \mathrm{~cm}$, to $-63 \mathrm{R}-6,16-19 \mathrm{~cm}$; depth: 1048.3-1001.9 mbsf; age: middle? Miocene.

The base of this zone is defined by the lowest persistent occurrence of Labyrinthodinium truncatum, and its top immediately underlies the lowest occurrence of Impagidinium aquaeductum. Notable species first appearing in this zone are Invertocysta tabulata, Pyxidinopsis sp. 3, Habibacysta tectata, and Labyrinthodinium sp. cf. L. truncatum. Notable species restricted to this zone include Impagidinium maculatum sensu Manum et al. (in press). Notable species last appearing in this zone are Distatodinium paradoxum s.l., cf. Tectatodinium $\mathrm{sp} .1$ of Manum, 1976, Pyxidinopsis sp. 2, Cyclopsiella spiculosa n. sp., and Acritarch sp. 2. The Pyxidiella/Pyxidinopsis group has its last regular occurrence in this zone.

\section{Discussion of Dinocyst Assemblage Zone BB3}

Well-established early Miocene records for $L$. truncatum are not known (other than this study, where this species occurred rarely in Zone BB2), but this species has been reported from a number of middle Miocene sites (see "Systematic Descriptions of Marine Palynomorphs" section, this chapter). Invertocysta tabulata was observed rarely in this study. The species has a known range of late Oligocene to late Miocene or Pliocene. Impagidinium maculatum sensu Manum et al. (in press) was recorded from the early Miocene to late Miocene of the Norwegian Sea (Manum et al., in press). D. paradoxum sensu lato, (see "Systematic Descriptions of Marine Palynomorphs" section, this chapter) has an LA that is evidently diachronous, ranging from early to early middle Miocene.

\section{Other Chronostratigraphic Data}

This zone does not have nannofossil control, although the early/middle Miocene nannofossil boundary occurs within the subjacent Zone BB2 (see "Discussion of Assemblage Zone BB2" section, this chapter, for discussion of boundary). In Sample 105-645E-67R-2, 89-91 cm, of assemblage Zone BB3, the pres- 
Table 2A. Stratigraphic distribution of marine palynomorph species recorded for the Miocene of Hole 645E, arranged according to ascending lowest occurrences. AGE (nannofossils: Knüttel et al., this volume) AGE (dinocysts: this chapter) DINOCYST ASSEMBLAGE ZONE (this chapter) ODP LEG 105, HOLE 645E:

CORE\#

SECTION\# (CC = core catcher sample) INTERVAL (in $\mathrm{cm}$ ) from:

\section{MARINE PALYNOMORPH SPECIES}

Xandarodinium sp. A

Batiacasphaera gemmata n. sp.

Batiacasphaera sp. ct. B. baculat

Evittosphaerula paratabulata

Distatodinium paradoxum s.l.

Systematophora ancyrea

Impletosphaeridium prolatum n. sp.

Cordosphaeridium minimum sensu Benedek and Sarieant Lingulodinium machaerophorum

- Palaeocystodinium golzowense

Lejeunecysta spp. (mainly L. fallax s.l.)

12 ct. Brigantedinium spp. of Head et al, a (this vol.)

3 Operculodinium centrocarpum s.

4 Reticulatosphaera actinocoronata

15 Batiacasphaera micropapillata "complex"

16 Impagidinium(?) pallidum

7 Nematosphaeropsis lemniscata

8 Selenopemphix sp. 1

19 Dinopterygium cladoides sensu Morgenroth

20 Lophocysta sp.

21 Melitasphaeridium choanophorum

22 Acritarch sp. 1

23 Pyxidiella/Pyxidiniopsis "group"

24 Acritarch sp. 2

25 Heteraulacacysta sp. A of Costa and Downie 1979

Dapsilidinium pseudocolligerum

Hystrichokolpoma rigaudiae

8 Paralecaniella indentata

29 Spiniferites/Achomosphaera spp.

30 Operculodinium sp.

31 Cribroperidinium tenuitabulatum

2 Lophocysta sp. of L Sulcolimba

33 Impagidinium sp. 1

Hystrichosphaeropsis sp. at. H. obscura

45 Yystichosphauropsis sp.

36 Apteodinium spiridoides

37 Cordosphaeridium cantharellum (DR?)

38 Gen. et sp. indet. Piasecki 1980 "group

39 Palaeocystodinium cf. golzowense sensu Powell, 1986

40 Impagidinium sp. 7

41 Labyrinthodinium truncatum

42 Pyxidinopsis? sp.

\begin{tabular}{|l|l}
43 & Pyxidinopsis sp. 2 \\
44 & Thalassiphora? sp.
\end{tabular}

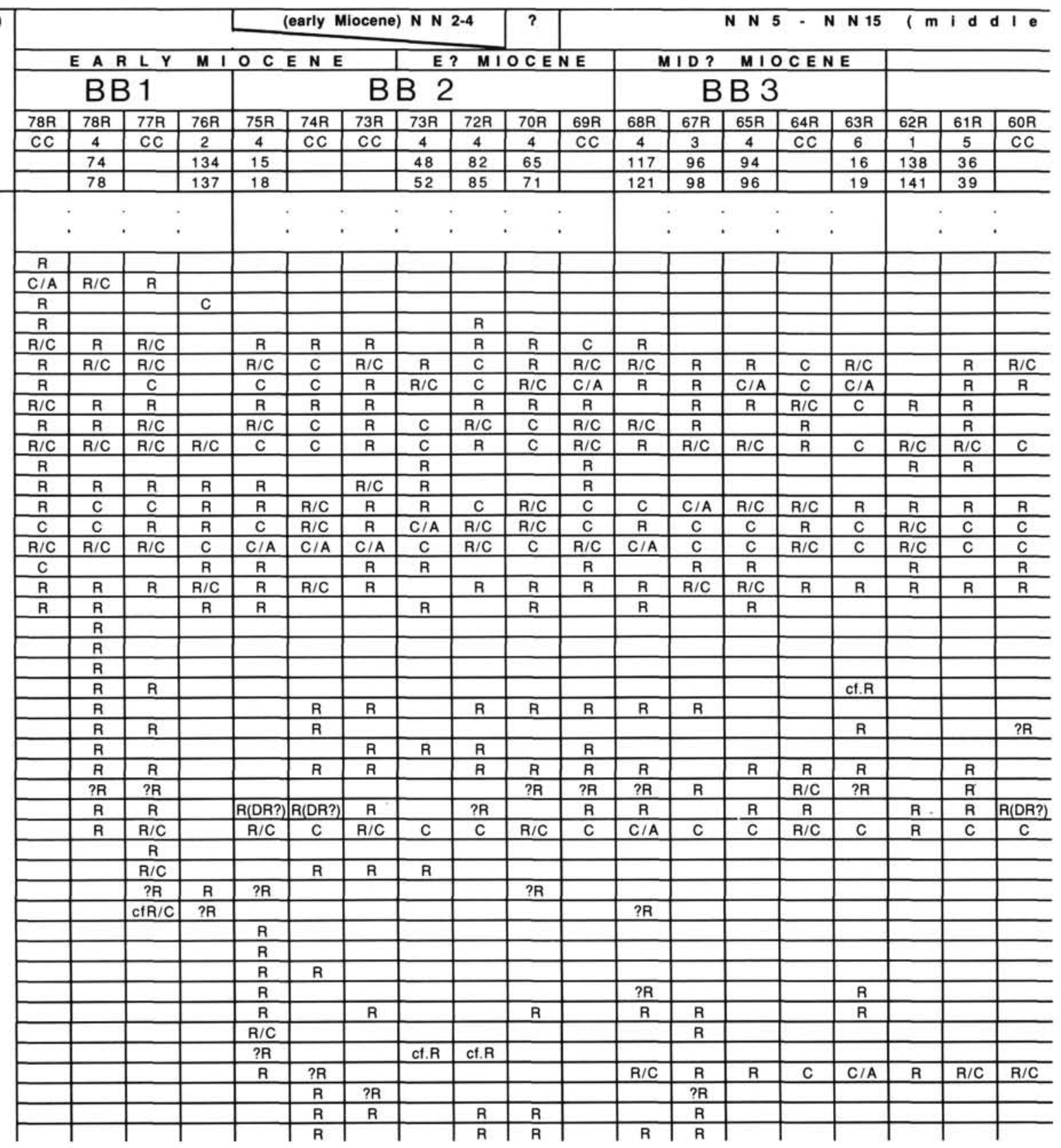


45 Selenopemphix brevispinosa n. sp.

46 Nematosphaeropsis down

47 Sumatradinium sp. B

48 ct. Tectatodinium sp. 1 Manum 1976

49 Sumatradinium Sp. of Duffield and Stein 1986

50 Cymatiosphaera? baffinensis $n . s p$.

Sumatradinium sp. A

Batiacasphaera sphaerica

4 Selenopemphix nephroides

55 Nematosphaeropsis labyrinthea

56 Cyclopsiella spiculosa $n$ sp.

57 Impagidinium sp. 4

58 Spiniferites pseudofurcatus

59 Cerebrocysta? sp 1

60 Pentadinium laticinctum laticinctum

6rinadinum laticinclum

62 Operculodinium israelianum

63 Impagidinium maculatum sensu Manum et al., (in press)

4 Batiacasphaera? sp.

65 Impagidinium sp. 6

66 Invertocysta tabulata

67 Pyxidinopsis sp. 3

68 Selenopemphix sp. 3

69 ct. Cannosphaeropsis sp. A Wrenn and Kokinos 1986

Nematosphaeropsis sp. A

Habibacysta tectata Head et al., b (this vol.)

72 Cymatiosphaera? sp.

3 Trinovantedinium? sp.

74 Trinovantedinium sp. B

75 Labyrinthodinium sp. of L truncatum

76 Impagidinium spp.

77 Impagidinium aquaeductum

Penidinium aqua

Impagidinim sp.

Peagidinium sp. 2

Pentadinium? sp. A

Cristadinium sp. 1

ct. Gen. et sp. indet. Piasecki 1980

4 Spiniferites sp. 1

85 Cannosphaeropsis? sp. 1

6 Impletosphaeridium sp. 1

87 Operculodinium vacuolatum n. sp.

Scolecodont

Pyxidinopsis? sp. 4

90 Cristadinium cristatoserratum Head et al., b (this vol.)

Impagidinium sp. ct. I. paradoxum

Leiosphaeridia sp.

Cristadinium sp. 2

4 Cymatiosphaera? invaginata Head et al., b (this vol.)

Apteodinium sp. 1

Ampagidinium velorum

Cyclopsiella? sp. cf. C? trematophora

Pentadinium laticinctum subsp. A

99 Impagidinium sp. 3

\begin{tabular}{l|l}
99 & Impagidinium $5 p .3$ \\
100 & Impagidinium patulum
\end{tabular}

01 Tuberculodinium vancampoae

102 Xandarodinium variabile

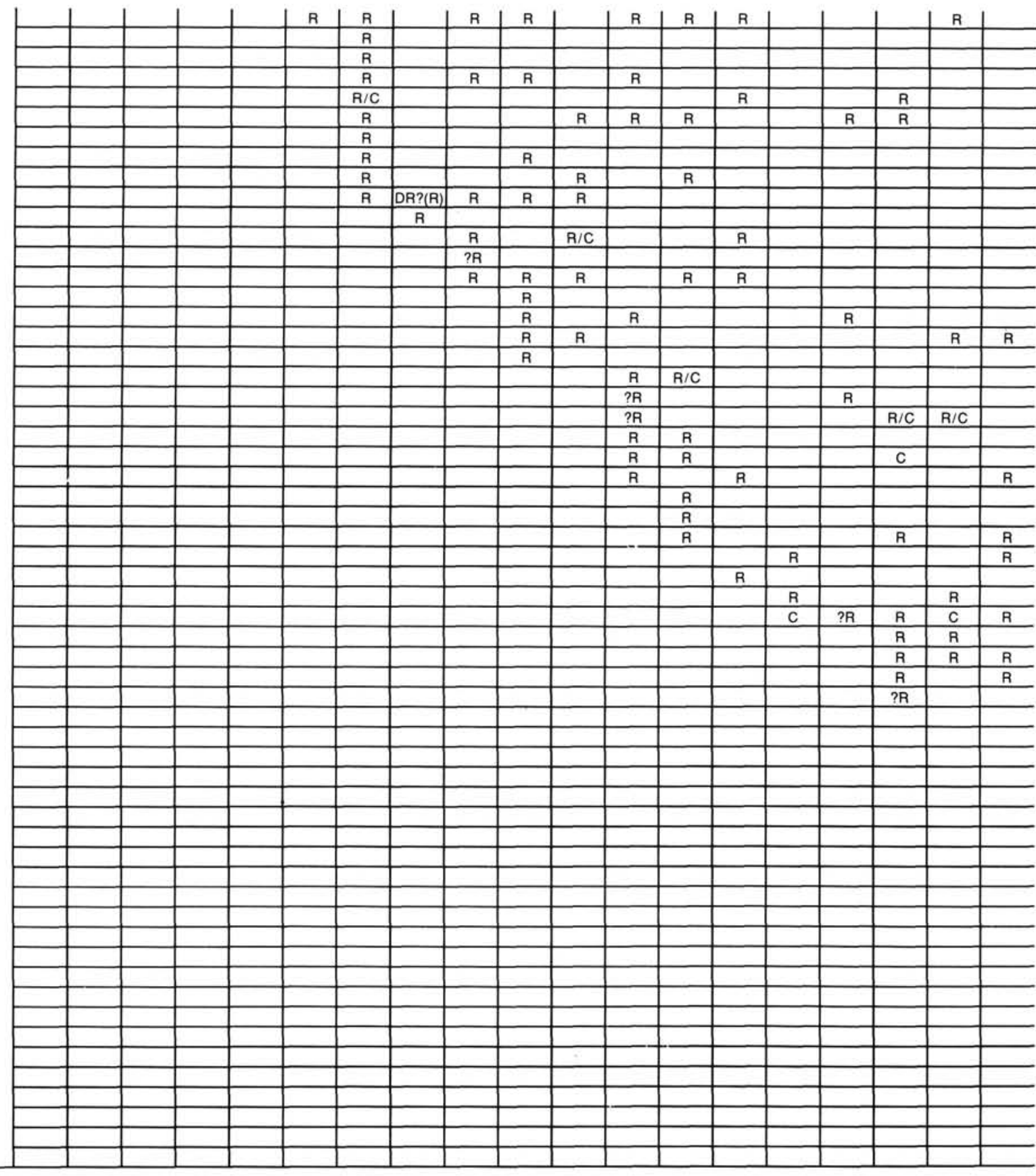


Table 2A (continued).

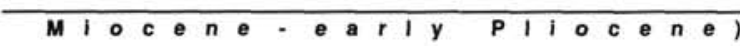

\begin{tabular}{c|c|c|}
\hline MIODLE MIOCENE THAOUGH EARLY LATE? MIOCENE & B MID TO LATE MIOCENE \\
\hline B B 4 & B B 5
\end{tabular} \begin{tabular}{|l|l|l|l|l|l|l|l|l|l|l|l|l|l|l|l|l|l|l|l|l|l|l|l|l|l|}
\hline $60 \mathrm{R}$ & $57 \mathrm{R}$ & $56 \mathrm{R}$ & $55 \mathrm{R}$ & $54 \mathrm{R}$ & $52 \mathrm{R}$ & $50 \mathrm{R}$ & $49 \mathrm{R}$ & $48 \mathrm{R}$ & $46 \mathrm{R}$ & $45 \mathrm{R}$ & $43 \mathrm{R}$ & $40 \mathrm{R}$ & $38 \mathrm{R}$ & $37 \mathrm{R}$ & $35 \mathrm{R}$ & $34 \mathrm{R}$ & $33 \mathrm{R}$ & $30 \mathrm{R}$ & $28 \mathrm{R}$ & $26 \mathrm{R}$ & $24 \mathrm{R}$ & $22 \mathrm{R}$ & 20 & 19 & 18 \\
\hline
\end{tabular}

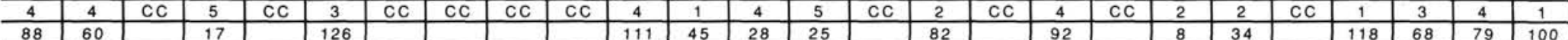

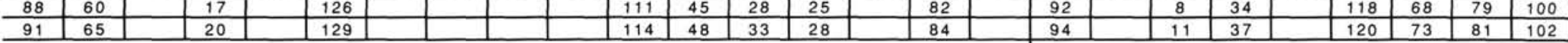

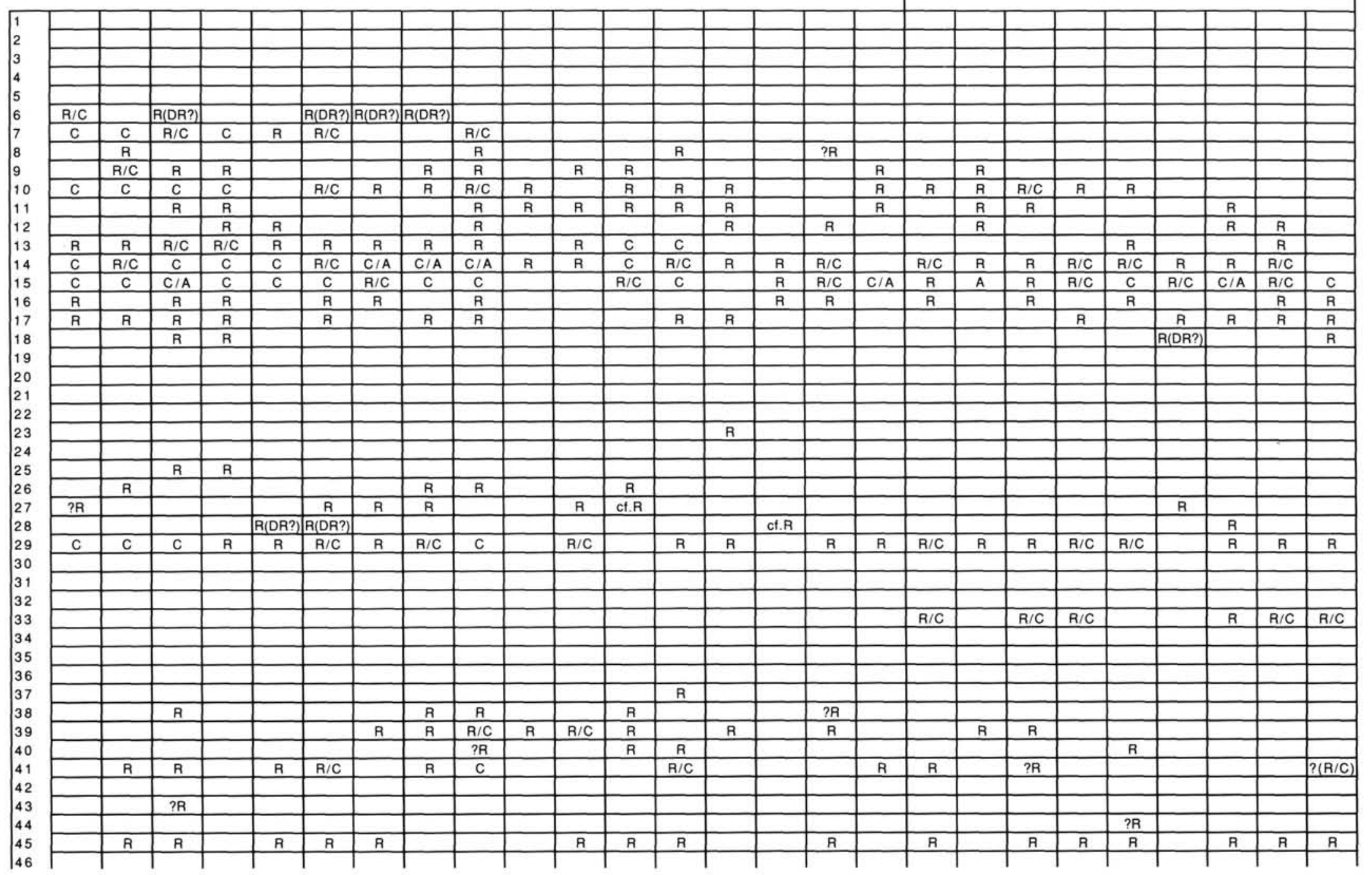




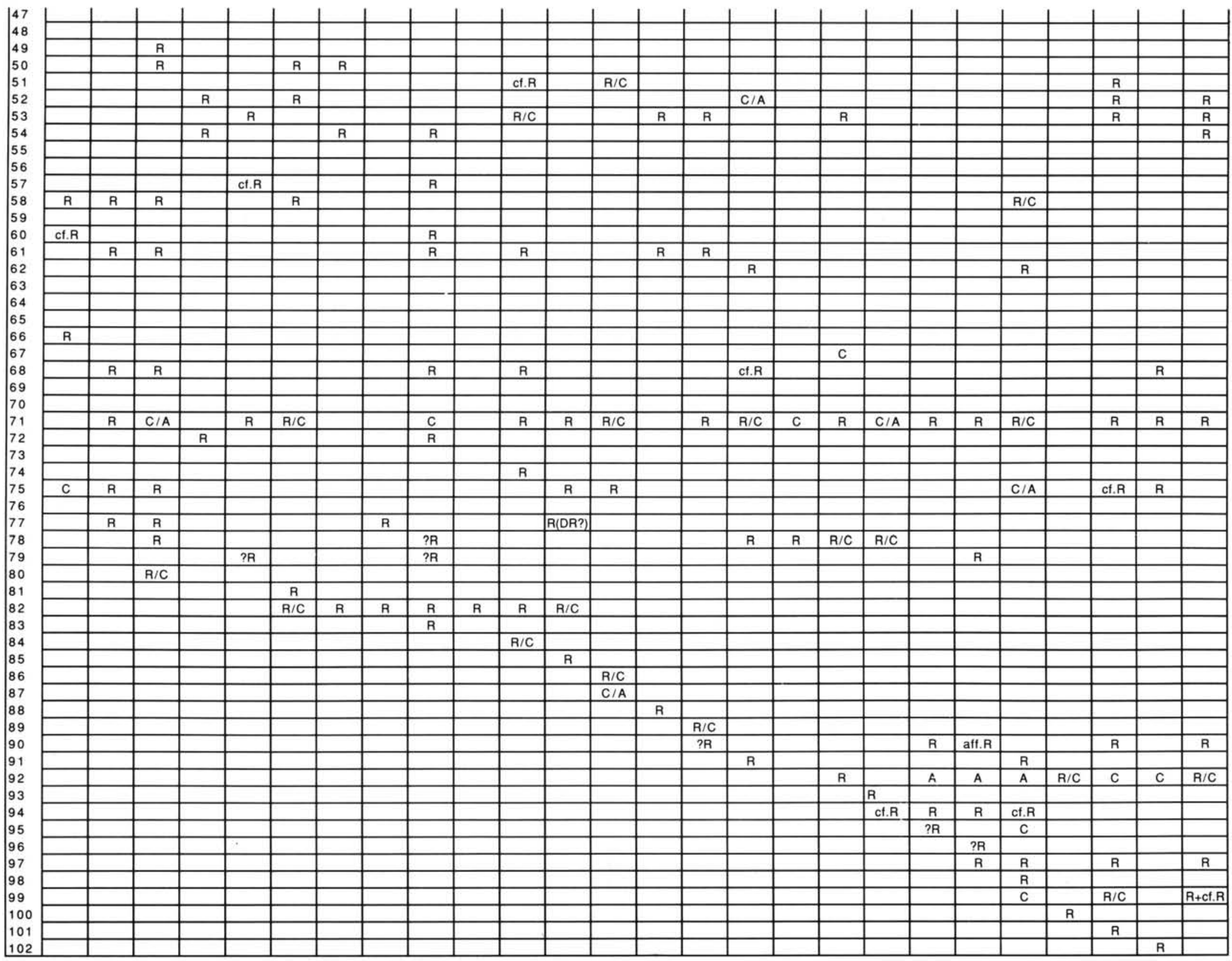
Note: Age determinations using the geochronology of Berggren et al. (1985) are indicated separately both for dinocysts (this study) and nannofossil zones (Knüttel et al., this volume). $\mathrm{R}=$ rare, $\mathrm{C}=$ com-
mon, and $\mathrm{A}=$ abundant, and record approximate visual estimates of the abundance of taxa in each sample. $\mathrm{DR}=$ presumed reworking. Sample quality (i.e., freedom from drilling slurry) is high in all
samples. samples. 
Table 2B. Stratigraphic distribution of marine palynomorph species recorded for the Miocene of Hole 645E, arranged according to ascending highest occurrences.

\begin{tabular}{|c|c|c|c|c|c|c|c|c|c|c|c|c|c|c|c|c|c|c|c|}
\hline \multirow{7}{*}{$\begin{array}{l}\text { AGE (nannofossils: Knüttel et al., this volume) } \\
\text { AGE (dinocysts: this chapter) } \\
\text { DINOCYST ASSEMBLAGE ZONE (this chapter) } \\
\text { ODP LEG 105, HOLE 645E: } \\
\text { CORE\# } \\
\text { SECTION\# (CC = core catcher sample) } \\
\text { INTERVAL (in cm) from: } \\
\text { to: }\end{array}$} & & & & & \multicolumn{5}{|c|}{ (early Miocene) N N 2-4 $^{-}$} & $?$ & \multicolumn{9}{|c|}{ N N $5 \cdot N_{15}(\mathrm{~m}$ idd d I e } \\
\hline & \multirow{2}{*}{\multicolumn{4}{|c|}{$\begin{array}{l}E A R L Y \\
B B 1\end{array}$}} & \multirow{2}{*}{\multicolumn{5}{|c|}{$\begin{array}{c}\text { OCENE } \\
\text { BB } 2\end{array}$}} & $O C E$ & & \multicolumn{5}{|c|}{ MID? MIOCENE } & \multirow[b]{3}{*}{$62 \mathrm{R}$} & \multirow[b]{3}{*}{$61 \mathrm{R}$} & \multirow[b]{3}{*}{$60 R$} \\
\hline & & & & & & & & & & & & \multicolumn{5}{|c|}{ BB 3} & & & \\
\hline & $78 \mathrm{R}$ & & $77 \mathrm{R}$ & $76 \mathrm{R}$ & $75 R$ & $74 R$ & $73 \mathrm{R}$ & $73 \mathrm{R}$ & $72 R$ & $70 R$ & $69 \mathrm{R}$ & $68 \mathrm{R}$ & $67 R$ & $65 \mathrm{R}$ & $64 \mathrm{R}$ & $63 R$ & & & \\
\hline & $\mathrm{CC}$ & 4 & $\mathrm{CC}$ & 2 & 4 & $\mathrm{CC}$ & $\mathrm{CC}$ & 4 & 4 & 4 & $\mathrm{CC}$ & 4 & 3 & 4 & $\mathrm{CC}$ & 6 & 1 & 5 & $\mathrm{CC}$ \\
\hline & & 74 & & 134 & 15 & & & 48 & 82 & 65 & & 117 & 96 & 94 & & 16 & 138 & 36 & \\
\hline & & 78 & & 137 & 18 & & & 52 & 85 & 71 & & 121 & 98 & 96 & & 19 & 141 & 39 & \\
\hline MARINE PALYNOMORPH SPECIES & \multicolumn{2}{|c|}{ 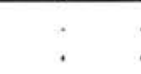 } & \multicolumn{2}{|c|}{ t } & & & & & & & & & & & & & & & \\
\hline Xandarodinium sp. A & $\mathrm{R}$ & & & & & & & & & & & & & & & & & & \\
\hline Dinopterygium cladoides sensu Morgenroth & & $\mathrm{R}$ & & & & & & & & & & & & & & & & & \\
\hline Lophocysta sp. & & $R$ & & & & & & & & & & & & & & & & & \\
\hline Melitasphaeridium choanophorum & & $\mathrm{R}$ & & & & & & & & & & & & & & & & & \\
\hline Batiacasphaera gemmata n. sp. & $\mathrm{C} / \mathrm{A}$ & $\mathrm{R} / \mathrm{C}$ & $\mathrm{R}$ & & & & & & & & & & & & & & & & \\
\hline Operculodinium sp. & & & $R$ & & & & & & & & & & & & & & & & \\
\hline Batiacasphaera sp. ct. B. baculata & $\mathrm{R}$ & & & $\mathrm{C}$ & & & & & & & & & & & & & & & \\
\hline Hystrichosphaeropsis sp. cf. H. obscura & & & & & $\mathbf{R}$ & & & & & & & & & & & & & & \\
\hline Selenopemphix? sp. 2 & & & & & $\mathrm{R}$ & & & & & & & & & & & & & & \\
\hline Acritarch sp. 1 & & $\mathbf{R}$ & $R$ & & & & & & & & & & & & & cf.R & & & \\
\hline Apteodinium spiridoides & & & & & $\mathrm{R}$ & $\mathrm{R}$ & & & & & & & & & & & & & \\
\hline Pyxidinopsis? sp. 1 & & & & & & $\mathrm{~A}$ & ?R & & & & & & ?R & & & & & & \\
\hline Nematosphaeropsis downii & & & & & & & $\mathrm{R}$ & & & & & & & & & & & & \\
\hline Sumatradinium $s p$. B & & & & & & & $\mathrm{R}$ & & & & & & & & & & & & \\
\hline Cribroperidinium tenuitabulatum & & & $\mathrm{R} / \mathrm{C}$ & & & $\mathrm{A}$ & $R$ & $\mathrm{R}$ & & & & & & & & & & & \\
\hline Nematosphaeropsis labyrinthea & & & & & & & & $\mathrm{R}$ & & & & & & & & & & & \\
\hline Evittosphaerula paratabulata & $\mathrm{R}$ & & & & & & & & $\mathrm{R}$ & & & & & & & & & & \\
\hline Lophocysta sp. cf. L. sulcolimbata & & & ?R & $\mathrm{R}$ & ?R & & & & & ?R & & & & & & & & & \\
\hline Cerebrocysta? sp. 1 & & & & & & & & & & $\mathrm{R}$ & & & & & & & & & \\
\hline Distatodinium paradoxum s.l. & $\mathrm{R} / \mathrm{C}$ & $\mathrm{R}$ & $\mathrm{R} / \mathrm{C}$ & & $R$ & $R$ & $\mathbf{R}$ & & $\mathrm{R}$ & $R$ & c & $\mathrm{R}$ & & & & & & & \\
\hline cf. Tectatodinium sp. 1 Manum 1976 & & & & & & & $\mathrm{R}$ & & $R$ & $R$ & & $\mathrm{R}$ & & & & & & & \\
\hline Pyxidiella/Pyxidiniopsis "group" & & $\mathrm{A}$ & & & & $\mathrm{R}$ & $\mathrm{R}$ & & $\mathrm{R}$ & $\mathrm{R}$ & $\mathrm{R}$ & $\mathrm{R}$ & $\mathrm{R}$ & & & & & & \\
\hline Pyxidinopsis sp. 2 & & & & & & $\mathrm{R}$ & $\mathrm{B}$ & & $R$ & $\mathrm{R}$ & & & $R$ & & & & & & \\
\hline Thalassiphora? sp. 1 & & & & & & $R$ & & & $\mathrm{R}$ & $R$ & & $\mathrm{R}$ & $R$ & & & & & & \\
\hline Impagidinium maculatum sensu Manum et al., (in press) & & & & & & & & & & & & $R$ & $\mathrm{R} / \mathrm{C}$ & & & & & & \\
\hline ct. Cannosphaeropsis sp. A Wrenn and Kokinos 1986 & & & & & & & & & & & & & $\mathrm{R}$ & & & & & & \\
\hline Nematosphaeropsis sp. A & & & & & & & & & & & & & $\mathrm{R}$ & & & & & & \\
\hline Cyclopsiella spiculosa n. sp. & & & & & & & & & $\mathrm{R}$ & & $\mathrm{R} / \mathrm{C}$ & & & $\mathbf{R}$ & & & & & \\
\hline Trinovantedinium? sp. C & & & & & & & & & & & & & & $R$ & & & & & \\
\hline Acritarch sp. 2 & & $\mathrm{R}$ & $\mathrm{R}$ & & & $\mathrm{R}$ & & & & & & & & & & $\bar{R}$ & & & ?R \\
\hline Batiacasphaera? sp. 1 & & & & & & & & & & & & ?R & & & & $\mathrm{A}$ & & & \\
\hline Impagidinium sp. 6 & & & & & & & & & & & & ?R & & & & & $\mathrm{R} / \mathrm{C}$ & $\mathrm{R} / \mathrm{C}$ & \\
\hline Systematophora ancyrea & $\mathrm{A}$ & $\mathrm{R} / \mathrm{C}$ & $\mathrm{R} / \mathrm{C}$ & & $\mathrm{R} / \mathrm{C}$ & C & $\mathrm{R} / \mathrm{C}$ & $\mathrm{R}$ & $\mathrm{C}$ & $\mathrm{R}$ & $\mathrm{R} / \mathrm{C}$ & $\mathrm{R} / \mathrm{C}$ & $\mathrm{R}$ & $\mathrm{R}$ & $\mathrm{C}$ & $\mathrm{R} / \mathrm{C}$ & & $\mathrm{A}$ & $\mathrm{R} / \mathrm{C}$ \\
\hline Invertocysta tabulata & & & & & & & & & & & & $\mathrm{R}$ & $\mathrm{R}$ & & & & & & \\
\hline Sumatradinium sp. of Duffield and Stein 1986 & & & & & & & $\mathrm{R} / \mathrm{C}$ & & & & & & & $\mathrm{A}$ & & & $\mathrm{R}$ & & \\
\hline Pentadinium? sp. A & & & & & & & & & & & & & & & & & & & \\
\hline Heteraulacacysta sp. A of Costa and Downie 1979 & & $R$ & & & & & $\mathrm{R}$ & $\mathrm{R}$ & $R$ & & R & & & & & & & & \\
\hline Cristadinium sp. 1 & & & & & & & & & & & & & & & & & & & \\
\hline Impletosphaeridium prolatum n. sp. & $\mathrm{R}$ & & $\mathrm{C}$ & & $\mathrm{C}$ & C & $\mathrm{R}$ & $\mathrm{R} / \mathrm{C}$ & C & $\mathrm{R} / \mathrm{C}$ & $\mathrm{C} / \mathrm{A}$ & $R$ & $\mathrm{R}$ & $\mathrm{C} / \mathrm{A}$ & C & $\mathrm{C} / \mathrm{A}$ & & $R$ & $\mathrm{R}$ \\
\hline Cymatiosphaera? baffinensis n. sp. & & & & & & & $R$ & & & & $\mathrm{R}$ & $\mathrm{R}$ & $R$ & & & $\mathrm{R}$ & $\mathrm{R}$ & & \\
\hline Impagidinium sp. 4 & & & & & & & & & ? $\mathrm{R}$ & & & & & & & & & & \\
\hline Pentadinium laticinctum laticinctum & & & & & & & & & & $\mathrm{R}$ & & $R$ & & & & R & & & \\
\hline Cymatiosphaera? sp. & & & & & & & & & & & & & & & $\mathrm{R}$ & & & & $\mathrm{R}$ \\
\hline Impagidinium spp. & & & & & & & & & & & & & & & & & $\bar{R}$ & $R$ & \\
\hline
\end{tabular}


45 |ct. Gen. et sp. indet. Piasecki 1980

46 Trinovantedinium sp.

48 Dapsilidinium pseudocolligerum

49 Impagidinium aquaeductum

50 Impagidinium sp. 5

51 Cannosphaeropsis? sp. 1

52 Cordosphaeridium minimum sensu Benedek and Sarjeant

3 Cordosphaeridium cantharellum (DR?)

4 Impletosphaeridium sp. 1

5 Operculodinium vacuolatum n. sp.

6 Scolecodont

Trinovantedinium sp.

Pyxidinopsis? sp. 4

Gen. et sp. indet. Piasecki 1980 "group

Pyxidinopsis sp. 3

Lingulodinium machaerophorum

Pentadinium sp. B

Cristadinium sp.

Palaeocystodinium cf. golzowense sensu Powell, $1986 \mathrm{~b}$

Impagidinium sp. 2

Impagidinium velorum

Palaeocystodinium golzowense

Impagidinium sp. 7

Spiniferites pseudofurcatus

Operculodinium israelianum

Impagidinium sp. ct. I. paradoxum

Cymatiosphaera? invaginata Head et al., b (this vol.)

Apteodinium sp.

Pentadinium laticinctum subsp. A

Hystrichokolpoma rigaudia

Impagidinium patulum

Lejeunecysta spp. (mainly L. fallax s.I.)

Paralecaniella indentala

Sumatradinium sp. A

Tuberculodinium vancampoae

cf. Brigantedinium spp. of Head et al, a (this vol.)

Operculodinium centrocarpum s.l.

Reticulatosphaera actinocoronata

Selenopemphix sp. 3

Labyrinthodinium so. ct. L. truncatum

Xandarodinium variabile

Batiacasphaera micropapillata "complex"

Impagidinium(?) pallidum

Nematosphaeropsis lemniscata

Selenopemphix sp. 1

Spiniterites/Achomosphaera spp.

Impagidinium sp. 1

Labyrinthodinium truncatum

Selenopemphix brevispinosa $n$. sp.

Batiacasphaera sphaerica

Microforaminiferal lining

Selenopemphix nephroides

Habibacysta tectata Head et al., b (this vol.)

9 Cristadinium cristatoserratum Head et al., b (this vol.)

00 Leiosphaeridia sp.

101 Cyclopsiella? sp. cf. C? trematophora 


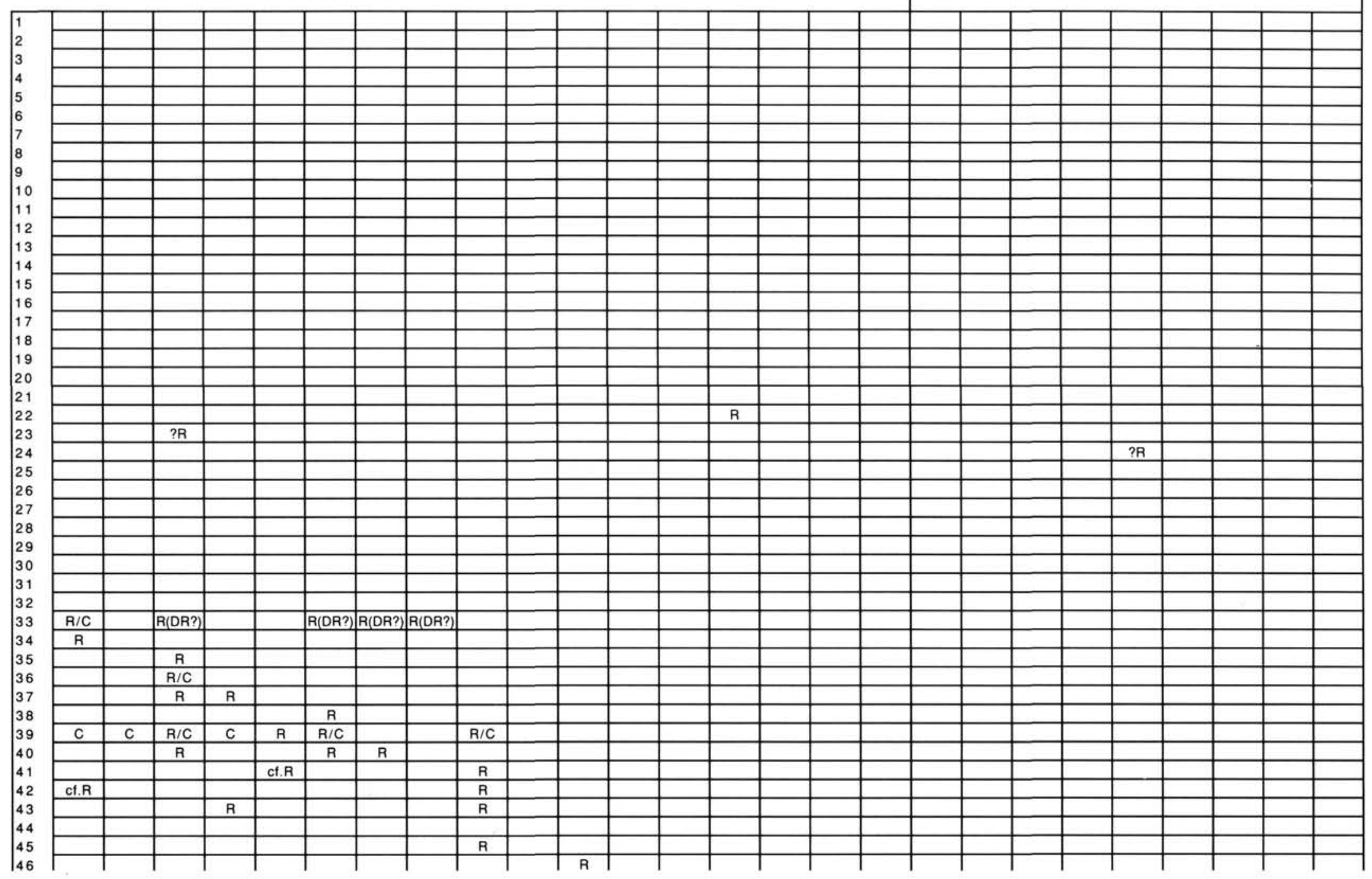




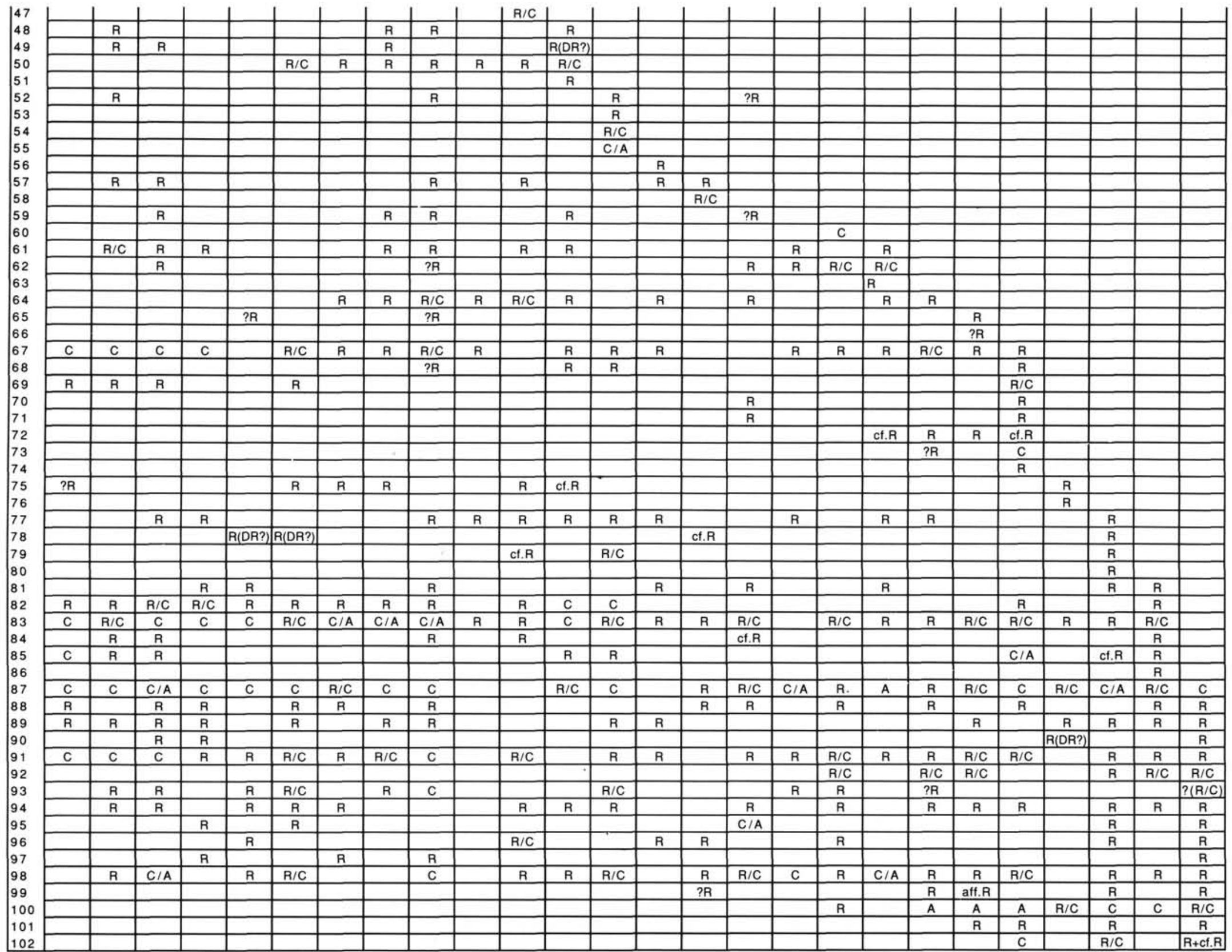

Note: Age determinations using the geochronology of Berggren et al. (1985) are indicated separately both for dinocysts (this study) and nannofossil zones (Knüttel et al., this volume). $\mathrm{R}=\mathrm{rare}, \mathrm{C}=\mathrm{com}-$ mon, and $\mathrm{A}=$ abundant, and record approximate visual estimates of the abundance of taxa in each sample. DR = presumed reworking. Sample quality (i.e., freedom from drilling slurry) is high in all samples. 
ence of the planktonic foraminifer Globigerina praebulloides allows us to correlate it tentatively with lower to lower middle Miocene sediments from the North Sea and lower Miocene sediments from the Labrador continental margin (Kaminski, Gradstein, Scott, and Mackinnon, this volume).

\section{Chronostratigraphic Summary for Zone BB3}

The absence of early Miocene species from this zone and the persistent presence of $L$. truncatum, tentatively suggests a middle Miocene age for Zone BB3 on the basis of dinocyst markers. The LA of $D$. paradoxum (in Sample 105-645E-68R-4, 117-121 $\mathrm{cm}$ ) indicates an age younger than early middle Miocene for the lowermost sample of Zone BB3.

Zone BB3, as here defined, compares closely with the Labyrinthodinium truncatum Zone of Piasecki (1980) from Denmark and the Labyrinthodinium truncatum Zone of Manum et al. (in press) from Leg 104 of the Norwegian Sea. However, one cannot correlate these zones precisely because of the uncertain age of the FA of L. truncatum (see "Systematic Descriptions of Marine Palynomorphs" section, this chapter), which defines the base of both zones.

\section{Dinocyst Assemblage Zone BB4}

Samples 105-645E-62R-1, 138-141 cm, to -34R, CC; depth: 987.4734.0 mbsf; depth: middle Miocene to early late? Miocene.

The base of this zone is defined by the FA of Impagidinium aquaeductum. The top is defined immediately below the FA of Leiosphaeridia sp. Notable species first appearing in this zone are Impagidinium aquaeductum, Pentadinium sp. B, Impagidinium sp. 5, Impletosphaeridium sp. 1, Operculodinium sp. 1, Pyxidinopsis sp. 4, and Cristadinium cristatoserratum. Notable species last appearing within this zone include Systematophora ancyrea, Selenopemphix sp. 1, Heteraulacacysta sp. A of Costa and Downie, 1979, Impletosphaeridium prolatum n. sp., Cymatiosphaera? baffinensis n. sp., Pentadinium laticinctum laticinctum, Dapsilidinium pseudocolligerum, Impagidinium aquaeductum, Impagidinium sp. 5, Cordosphaeridium minimum sensu Benedek and Sarjeant, 1981, Impletosphaeridium sp. 1, Operculodinium sp. 1, Pyxidinopsis sp. 4, and "Gen et sp. indet. of Piasecki" group.

\section{Discussion of Dinocyst Assemblage Zone BB4}

Impagidinium aquaeductum has a range of early middle Miocene through early late Miocene (Haq et al., 1987; see "Systematic Descriptions of Marine Palynomorphs" section, this chapter) or Pliocene (Harland, 1978). This species has been recorded from a number of middle Miocene sites, but has not been found in sediments younger than late Miocene in high latitudes of the North Atlantic (Mudie, in press). The earliest wellconstrained FA of I. aquaeductum is at DSDP Site 406 of the Rockall Plateau (Costa and Downie, 1979), recorded from near the base of nannofossil Zone NN5 (Müller, 1979) and within planktonic foraminiferal $P$. glomerosa Zone (Krasheninnikova, 1979), thus placing this FA within the middle Miocene and near the early/middle Miocene boundary (see also Costa and Müller, 1978). Other records suggest that the FA of I. aquaeductum is diachronous, although at several sites, it has been placed within the earlier half of the middle Miocene.

$S$. ancyrea has a diachronous LA from middle to late Miocene (see "Systematic Descriptions of Marine Palynomorphs" section, this chapter). This species was not recorded from the late Miocene (Zones NN10 and NN11) of either Site 646, Labrador Sea (Head et al., a, this volume), or Site 642 , Norwegian Sea (Mudie, in press), and available records indicate that within the North Atlantic, this species does not extend higher than the early late Miocene. C. minimum sensu Benedek and Sarjeant, 1981 ranges up into the late Miocene (see "Systematic Descrip- tions of Marine Palynomorphs" section, this chapter) and has a last recorded appearance in the early late Miocene (lower nannofossil Zone NN11) of the Goban Spur (as cf. $C$. minimum in Brown and Downie, 1985). Elsewhere, however, this species has an LA in the middle Miocene (northwest Italy, planktonic foraminiferal Zone N12, in Powell, 1986b). The few records presently available for Gen. et sp. indet. of Piasecki are restricted to the Miocene. This species has a youngest known occurrence in the early? late Miocene (see "Systematic Descriptions of Marine Palynomorphs" section, this chapter).

Precise ranges of taxa are uncertain through much of Zone BB4 because of low recovery of dinocysts. Zone BB4 was not subdivided for this reason, although differences may occur between assemblages from the upper and lower parts of this zone.

\section{Other Chronostratigraphic Data for Zone BB4}

The age of dinocyst assemblage Zone BB4 is poorly constrained by other microfossil groups that occur only sporadically and contain mainly long-ranging taxa. The presence of the planktonic foraminifer Bolboforma metzmacheri in Sample 105$645 \mathrm{E}-36 \mathrm{R}, \mathrm{CC}$ constrains the age of this sample as no younger than nannofossil Zone NN16 (early Pliocene), as correlated with North Sea and North Atlantic species (Kaminski, Gradstein, Scott, and Mackinnon, this volume). The rare occurrence of the nannofossil Reticulofenestrata pseudoumbilica in Sample 105-645E-35R, CC and the occurrence of Coccolithus pelagicus in a few samples from Core 105-645E-35R through Sample 105$645 \mathrm{E}-70 \mathrm{R}-2,42-44 \mathrm{~cm}$, suggests that the interval from 734.7 to 1063.83 mbsf is equivalent to the "Interval with Reticulofenestrata pseudoumbilica" of Müller (1976) and correlative with Zones NN5 through NN15 of Martini (1971) of middle Miocene to early Pliocene age.

\section{Chronostratigraphic Summary for BB4}

Dinocyst data for this interval give an early? middle Miocene age for the base of Zone BB4, as indicated by the FA of $I$. aquaeductum in Sample 105-645E-62R-1, 138-141 cm. The top of Zone BB4 was determined to be no younger than early late Miocene, based on the presence of Palaeocystodinium golzowense, which occurs throughout this zone and is considered to have a highest LA within the lowermost part of nannofossil Zone NN11 (around 7 to $8 \mathrm{Ma}$ ). Other species supporting a middle to early late Miocene age for this zone include the LAs of C. minimum sensu Benedek and Sarjeant (in Sample 105$645 \mathrm{E}-40 \mathrm{R}-4,28-33 \mathrm{~cm}$ ) and $S$. ancyrea (in Sample 105-645E$60 \mathrm{R}-4,88-91 \mathrm{~cm})$.

Assemblage Zone BB4 of Site 645 apparently predates late Miocene sediments (nannofossil Zones NN9 and above) from Site 646, Labrador Sea, as suggested by large taxonomic differences between dinocyst assemblages at the two sites. An unconformity detected by seismic stratigraphy as reflector R2 (see "Lithostratigraphy and Seismic Stratigraphy for Hole 645E" section, this chapter) that is estimated to occur at about 912 mbsf within Zone BB4 was not recognized by dinocyst stratigraphy, although it may be partly responsible for significant differences between assemblages from the upper and lower parts of Zone BB4.

\section{Dinocyst Assemblage Zone BB5}

Samples 105-645E-33R-4, 92-94 cm, to -18R-1, 100-102 cm; depth: 720.7-591.0 mbsf; age: middle to late Miocene.

The base of this zone is defined by the first occurrence of Leiospharidia sp., but the top is not defined. Notable species restricted to this zone are Leiospharidia sp., Cristadinium cristatoserratum, Cymatiosphaera? invaginata, Apteodinium sp. 1, Cyclopsiella? sp. cf. C.? trematophora, Impagidinium sp. 3, Impagidinium sp. 1, Impagidinium patulum, and Pentadinium 
laticinctum subsp. A. Notable species occurring within this zone include Pyxidinopsis sp. 3, Pentadinium sp. B, Palaeocystodinium golzowense sensu Powell, 1986, Impagidinium sp. 2, P. golzowense, Hystrichokolpoma rigaudiae, and Spiniferites pseudofurcatus.

\section{Discussion of Dinocyst Assemblage Zone BB5}

The genus Palaeocystodinium (including $P$. golzowense) has an apparently diachronous LA within the North Atlantic and adjacent areas and ranges from late middle Miocene to early or middle late Miocene, with a youngest occurrence in the lowermost part of nannofossil Zone NN11 (around 7 to $8 \mathrm{Ma}$ ), both in the Goban Spur and the Rockall Plateau. Its absence from the late Miocene of Site 642, Norwegian Sea; Site 646, Labrador Sea (nannofossil Zones NN10 and NN11); and central North Atlantic (nannofossil Zones NN9? and NN10) suggest that 9 to $10 \mathrm{Ma}$ may be an equally appropriate estimate for the LA of this genus in Sample 105-645E-24R, CC in Baffin Bay.

Hystrichokolpoma rigaudiae last appears in the Pleistocene of Israel, Gulf of Mexico, and the western and northern Pacific. In the northern North Atlantic and contiguous areas, it has an earlier LA in the upper Miocene, which may be associated with late Miocene cooling (Head et al., a, this volume). In Baffin Bay, its postulated middle or upper Miocene highest occurrence thus conforms to the expectation of an equivalent or somewhat earlier LA, as compared with its occurrence elsewhere in the northern North Atlantic and contiguous areas. $H$. rigaudiae has a highest persistent occurrence in Baffin Bay within dinocyst assemblage Zone BB4, although it was recorded rarely in a single sample (Sample 105-645E-22R-1, 118-120 cm), within dinocyst assemblage Zone BB5.

None of the dinocyst assemblage zones erected for ODP Site 646 from the late Miocene of the Labrador Sea (Head et al., a, this volume) are closely comparable with Zone BB5 from Site 645 , but some taxonomic similarities were noted, such as the occurrence of Cymatiosphaera? invaginata Head et al. (b, this volume) and Cristadinium cristatoserratum Head et al. (b, this volume). Environmental factors probably account for some of the differences in dinocyst assemblages, although the large difference in species composition may also indicate that Zone BB5 predates the late Miocene (nannofossil Zones NN9 and above) of Site 646 .

\section{Other Chronostratigraphic Data for BB5}

Magnetostratigraphic control is weak for Hole $645 \mathrm{E}$, but a long normal polarity interval from 679 to 613 mbsf was tentatively correlated with Chron 11 (Srivastava, Arthur, et al., 1987, p. 111). Chron 11 spans the early Tortonian, and its base is correlated with the middle/late Miocene boundary (Berggren et al., 1985). On this basis the middle/late Miocene boundary in Hole $645 \mathrm{E}$ may be placed within Core 105-645E-28R (679 mbsf), thus placing the three lowest samples of dinocyst assemblage Zone BB5 within the middle Miocene.

\section{Chronostratigraphic Summary for BB5}

Dinocysts provide the main biostratigraphic control for Zone BB5. Sample 105-645E-24R, CC, was determined to be no younger than early late Miocene, based on the occurrence of Palaeocystodinium golzowense, which is considered to have a highest LA within the lowermost part of nannofossil Zone NN11 (around 7 to $8 \mathrm{Ma}$ ). One cannot correlate Zone BB5 precisely with dinocyst zonal schemes erected elsewhere, probably because of the influence of unusual environmental factors at this site.

Evidence from both magnetostratigraphy and nonpalynological microfossil biostratigraphy is weak for this zone, but is not in disagreement with age estimates based on dinocyst stratigra- phy. A possible magnetostratigraphic recognition of Chron 11 at Site 645 allowed us to place the middle/late Miocene boundary tentatively within Core 105-645E-28R (679 mbsf), in the lower part of Zone BB5.

\section{SPOROMORPH ASSEMBLAGES}

Spores and pollen are the dominant palynomorph components of most samples examined (see Pls. 1 and 2). These components consist mainly of coniferous tree pollen (Pinus, Picea, and Tsuga [Pl. 1, Fig. 15] make up about $50 \%$ of the sporomorphs in most samples below Core 105-645E-11R) and trilete fern spores. Other pollen and spore taxa are present in small numbers and were not studied in detail. Initial observations of their ranges, however, indicate trends that may be climatically controlled. Taxa presently found in warm-to-cool temperate areas occur commonly throughout the section below Core 105-645E20R and include species referable to Ilex, Ulmus, Sciadopitys (Pl. 1, Figs. 16,17; mainly Sciadopityspollenites serratus [Pot. and Ven.] Raatz, 1937), Betula tree pollen $(>30 \mu \mathrm{m})$, and $\mathrm{Al}$ nus, and fern spores of osmundaceous (Baculatisporites commaumenis [Cookson 1953] Potonié, 1956 s.l.) and lycopodiaceous (Reticulatisporites austroclavatidites s.l.) affinities. Species that are restricted to or occur more frequently in the middle to lower part of Hole 645E (i.e., below the middle of dinocyst assemblage Zone BB4 from about Samples 105-645E-54R, CC to $-46 \mathrm{R}, \mathrm{CC}$ ) are referable to Fagus (Pl. 1, Fig. 18), Carya, Pterocarya, Liquidambar, Tilia (Pl. 2, Figs. 6,7), and Juglans. These tree genera are warm-temperate deciduous forest species. Species that are restricted to or occur more frequently in the upper part of Hole $645 \mathrm{E}$ of this study (i.e., from about Sample 105-645E-46R, CC and above) include spores referable to Reticulosporis (a schizaeaceous spore genus; two species are illustrated in Pl. 2, Figs. 16, 18), Selaginella (Pl. 2, Figs. 10, 15), Sphagnum, pollen of Ericales, and Betula Sect. Nanae $(<30$ $\mu \mathrm{m}$; Pl. 1, Fig. 13); these are mainly temperate-to-subarctic, shrubby and herbaceous taxa. A pollen species referable to Lonicera (Pl. 1, Figs. 1-4, 11) is scattered and few can be seen in the upper part of Hole 645E of this study (from Samples 105$645 \mathrm{E}-60 \mathrm{R}, \mathrm{CC}$ to $-30 \mathrm{R}, \mathrm{CC}$ ), although the climatic significance of this is not known. In addition, a notable uphole decrease occurs in average concentration of pollen and spores, from a maximum of $16,800 / \mathrm{g}$ dry weight in dinocyst assemblage Zone BB3 and an average of $11,920 / \mathrm{g}$ in Zones BB2 and BB3 to an average of $1229 / \mathrm{g}$ above Core 105-645E-46R.

From the preliminary evidence presented above, we suggest that a warm-temperate deciduous and coniferous forest vegetation prevailed nearby in this part of the eastern Canadian Arctic during the early and early middle Miocene. During the middle or early late Miocene, this source vegetation was replaced by cooler temperate forests, with extensive open areas of meadowtype vegetation. This change probably occurred in response to climatic cooling associated with early glaciation of highland areas (Mudie and Helgason, 1983). A similar paleoclimatic trend was observed in sporomorph assemblages of wells on the Labrador continental margin (V.E. Williams, 1986). Note also that Sphagnum (peat moss) species first become dominant (about $50 \%$ of total sporomorphs) in Section 105-645E-11R-1 at about $75 \mathrm{~m}$ above Core 105-645E-19R, which contains the earliest possible ice-rafted sediment. Sphagnum moss is a good indicator of subarctic climatic conditions and is the prevalent sporomorph in Pliocene to lower Pleistocene sediments of Hole 645B (de Vernal and Mudie, this volume).

Of additional interest is the presence of mainly isolated specimens of the spore taxa Radialisporis radiatus (W. $\mathrm{Kr}$ ) W. $\mathrm{Kr}$, 1967 (Pl. 2, Fig. 17), Hazaria sp. (Pl. 2, Fig. 11), Reticulosporis spp. (Pl. 2, Figs. 16,18) and Favoisporites trifavus W. Kr. 1959 (common in Sample 105-645E-37R, CC; Pl. 2, Figs. 4,5), and 
the pollen species Persicarioipollis sp. (pollen of Polygonum? sp.; Pl. 1, Figs. 9, 10) and Saxonipollis sp. (pollen of Aldrovandra; Pl. 1, Figs. 7,8). Several of these species closely resemble taxa that range down into the lower Paleogene of the Canadian Arctic (Doerenkamp et al., 1976; Ioannides and McIntyre, 1980; Head, pers obs.) and Spitsbergen (Head, pers obs.) and thus might be reworked, although their preservation suggests that they are in situ. Other occasionally occurring pollen taxa of note are a lophate compositaceous species (Sample 105-645E28R-2, 8-11 cm; Pl. 1, Fig. 12), Chenopodiaceae/Amaranthaceae sp. (Sample 105-645E-60R-4, 88-91 cm; Pl. 1, Fig. 14), Nuphar sp. (recorded sporadically throughout, although more frequently occurring in upper Zone BB4 and Zone BB5; Pl. 2, Figs. 8,9,14), and cf. Weigela sp. (Pl. 2, Figs. 1-3), which occurs rarely (no more than one specimen per slide) but fairly persistently in Samples 105-645E-76R-2, 134-137 cm, through -61R-5, $36-39 \mathrm{~cm}$, and with a higher occurrence represented by a single specimen in Sample 105-645E-28R-2, 8-11 cm.

\section{DINOFLAGELLATE PALEOECOLOGY AND PALEOCEANOGRAPHY}

Interpretations of surface water mass origins (i.e., Arctic Ocean vs. North Atlantic) from Miocene dinocyst data at Site 645 are restricted by the scarcity of published information on Miocene Arctic dinocyst assemblages generally (see "Other Miocene Palynological Studies" section, this chapter) and by the absence of detailed data from Arctic Ocean deep-sea sediments older than early Pliocene (Aksu and Mudie, 1985). In addition, detailed paleoenvironmental interpretations are presently hindered by a poor understanding of the ecology of many Miocene dinoflagellate species. Nonetheless, some general interpretations and speculation, based on occurrences of dinoflagellates and sporomorphs and other data from Site 645 , can be made as follows:

1. The low representation of oceanic species, such as Impagidinium spp., and Invertocysta spp. (as compared with central North Atlantic sites), the persistent presence of Nematosphaeropsis lemniscata (outer neritic to oceanic), and the diverse representation of protoperidineacean species (inner neritic) indicates that conditions in Baffin Bay were neritic rather than fully oceanic at this time, as might be expected for a fairly shallow (a water depth of about $750 \mathrm{~m}$ ) silled basin. This observation agrees with shelf-type nannofossil assemblages in the lower Miocene of Site 645 (Srivastava, Arthur, et al., 1987, p. 93). Diverse protoperidineacean dinoflagellate species at Site 645 may indicate either the presence of nutrient-rich surface waters in Baffin Bay, cold water-surface temperatures (see discussion in Head et al., a, this volume) or frequent downslope transport of shelf sediment in fine-grained turbidity currents.

2. The absence of the warm-water dinocyst taxa Tuberculodinium (except for a single specimen recorded in Sample 105645E-20R-3, 68-73 cm) and Polysphaeridium, and the persistence of small numbers of the boreal to subarctic species Impagidinium(?) pallidum, which is now common in surface sediments of the eastern Arctic Ocean (Mudie, pers. obs.), indicate cool water conditions prevailed during deposition of the section studied. Where present, nannofossils are sporadic and rare. They occur with low diversity, and also suggest cold water conditions throughout much of the section down to Core 105-645E-70R. Assemblages below the early/middle Miocene boundary (below Cores 105-645E-70R through -73R) have increased diversity, however, and indicate cool-temperate surface waters (Srivastava, Arthur, et al., 1987, p. 93). Scattered calcareous benthic foraminifers found in the middle Miocene are also boreal in nature $(\mathrm{Ka}-$ minski, Gradstein, Scott, and Mackinnon, this volume). Thus, apparently, Baffin Bay was not strongly influenced by proto-
Gulf Stream water masses during this period, although sporomorphs in Hole 645E and elsewhere (Wolfe, 1985; Norris, 1986) indicate warm or temperate climatic conditions for the early Miocene of Arctic Canada.

3. Dinocyst assemblages from Zones BB1 to BB3 (early and early middle Miocene) have taxonomic similarities with coeval assemblages from high-latitude North Atlantic sites. Assemblages also share some similarities with the Norwegian Sea (as do nannofossils, Srivastava, Arthur, et al., 1987, p. 92). In addition, several taxa occur that have not been reported elsewhere (e.g., Impletosphaeridium prolatum n. sp., Batiacasphaera gemmata $\mathrm{n} . \mathrm{sp}$.) and are possibly endemic. From the above data, and from the sedimentological and seismic interpretation that bottom water circulation was fairly vigorous, one can speculate that throughout the Miocene, Site 645 was overlain by a mixed Arctic/North Atlantic water mass, which included an East Greenland Current component, analogous to today's circulation. The inflow of Arctic water from the Nares Strait and Canadian Arctic Island channels at Site 645 cannot be determined at present as few data having well-constrained ages are available for high Arctic Miocene assemblages. More study will also be necessary to determine whether new species reported here represent a microfloral component endemic to Baffin Bay, or were also present in the Miocene Arctic Ocean.

4. Dinocyst assemblages from the middle to early late Miocene Zones BB4 and BB5 may be less diverse than for underlying zones and are notably characterized by a decrease in concentrations of palynomorphs. In addition, several taxa have LAs within Zone BB4, and some premature LAs occur relative to ranges in other parts of the North Atlantic (e.g., D. pseudocolligerum, Impagidinium aquaeductum). The reasons for these changes are not clear from the dinoflagellate data alone, although possible causes might be (1) climatic deterioration, (2) changes in sea level, or (3) changes in ocean currents, such as, for example, those postulated by Gradstein and Srivastava (1980).

Other events within Zone BB4 may also be linked to this reduction in diversity. For example, between Cores 105-645E-55R and $-56 \mathrm{R}$ a lithologic change marks the boundary between lithologic Subunits IIIB and IIIC. This boundary coincides approximately with the prominent seismic reflector R2 (at around 912 mbsf), which probably indicates a regional unconformity caused by erosional bottom waters (Srivastava, Arthur, et al., 1987).

Higher in the section and co-occurring with the lithologic Subunit IIIB/IIIA boundary, coarse agglutinated benthic foraminifers (Kaminski, Gradstein, Scott, and Mackinnon, this volume) have a last occurrence between Samples 105-645E-38R-3, $44-47 \mathrm{~cm}$, and $-38 \mathrm{R}-6,127-129 \mathrm{~cm}$ (about $770 \mathrm{mbsf}$ ). An equivalent event (or as a last common occurrence) occurs at the Pliocene/Pleistocene boundary in the Arctic Ocean (Scott et al., 1986), in the early Pliocene of the Beaufort Sea (Young and McNeil, 1984), at some DSDP sites in the Norwegian-Greenland Sea (Leg 38 Site Reports; Berggren and Schnitker, 1983), and in the late Miocene of ODP Site 646 in the Labrador Sea (Kaminski, Gradstein, Scott, and Mackinnon, this volume). This event appears to indicate increased bottom water circulation and in the Arctic Ocean has been related to the production of dense brines occurring during the formation of perennial sea ice (Scott et al., 1986; Kaminski, Gradstein, Scott, and Mackinnon, this volume). The dinocyst record is presently unable to verify this environmental interpretation for Site 645 , but of possible significance is the FA of the acritarch Leiosphaeridia sp. in Sample 105-645E-33R-4, 92-94 cm, at the base of Zone BB5 and particularly its abundant occurrence from Sample 105$645 \mathrm{E}-28 \mathrm{R}-2,8-11 \mathrm{~cm}$, to the top of Zone BB5, which suggests the onset of unusual ecological conditions. Also notable is that 
a species of Leiosphaera marks the distribution of ice-rafted detritus in recent sediments off eastern Canada (Mudie and Short, 1985). The earliest sedimentological evidence for ice rafting (namely, the presence of what have been interpreted as dropstones) at Site 645 occurs in Core 105-645E-19R. By constructing a sedimentary rate line, constrained at $16.2 \mathrm{Ma}$ for Core 105-645E-71R using nannofossils, and 8 to about $10 \mathrm{Ma}$ for Core $105-645 \mathrm{E}-24 \mathrm{R}$ using the LA of the dinocyst $P$. golzowense, we estimate an extrapolated age of 7.4 to approximately $9.5 \mathrm{Ma}$ (early to middle late Miocene) for the onset of ice rafting at Site 645 .

\section{SUMMARY AND CONCLUSIONS}

1. Dinocyst assemblages from the bottom of Hole 645E indicate an early Miocene age. The early/middle Miocene boundary cannot be identified with certainty from dinocyst markers, but does occur between Sample 105-645E-73R, CC (LA of $\mathrm{Ne-}$ matosphaeropsis downii) and Sample 105-645E-62R-1, 138-141 $\mathrm{cm}$ (FA of Impagidinium aquaeductum) and is tentatively drawn between Samples 105-645E-69R, CC and -68R-4, 117-121 cm (first persistent presence of Labyrinthodinium truncatum). The LA of Palaeocystodinium golzowense in Sample 105-645E-24R, $\mathrm{CC}$ indicates an age no younger than around 7 to $8 \mathrm{Ma}$ (late Miocene), which is consistent with tentative magnetostratigraphy placing this sample in Chron 11.

2. Dinocyst assemblages indicate temperate-to-cool surface water conditions throughout the interval studied and suggest neritic rather than oceanic conditions. Dinocyst assemblages have some affinities with the northern North Atlantic and Norwegian Sea ODP/DSDP sites, but also have a possible endemic component. The presence of a number of protoperidineacean cyst species at this site suggests unusual conditions, perhaps related to nutrient influx.

3. Within the upper part (middle to early late Miocene) of the succession investigated, there is an increase in terrigenous organic material that occurs with the apparent disappearance of a number of dinocyst taxa. This may be related to both an oceanographic event (as indicated by a regional unconformity and the extinction of benthic foraminifers) and to climatic deterioration, which is supported by preliminary interpretations from spore and pollen data and by proximity to ice-rafted sediments occurring a short distance below the highest sample examined in detail. The putative late Miocene initiation of a cold Labrador Current following the East Canadian Shelf immediately south of Baffin Bay (Gradstein and Srivastava, 1980) may be a related phenomenon.

4. The initiation of ice rafting in Baffin Bay is estimated from dinocyst stratigraphy to have occurred at between 7.4 and 9.5 Ma (late Miocene), which is consistent with reports of highlatitude late Miocene cooling elsewhere in the Northern Hemisphere (e.g., Mudie and Helgason, 1983, and references therein).

\section{SYSTEMATIC DESCRIPTIONS OF MARINE PALYNOMORPHS}

\section{(With Notes on Paleoecology and Stratigraphic Distribution)}

This section contains notes on selected species recorded at Site 645. For additional comments on certain species (see Table $1)$, the reader is referred to Head et al. (a and b, this volume). Cyst dimensions are usually expressed as maximum and minimum values and given either side of the mean value, which is in parentheses.

Abbreviations used in plate captions include: Optical system: $\mathrm{BF}=$ bright field $\mathrm{IC}=$ interference contrast. If $=$ low focus, lrf = lower focus, $\mathrm{mf}=$ mid focus, $\mathrm{hf}=$ high focus, hrf = higher focus); dia. = maximum (unless stated otherwise) diameter; dia. (incl./excl. proc.) $=$ diameter (including/excluding processes); $\mathrm{dv}=$ dorsal view; $\mathrm{vv}=$ ventral view; $\mathrm{ds}=$ dorsal surface; vs = ventral surface. All samples indicated are from Hole 645E. For each figured specimen, information is provided in sequence, as follows: sample number, microscope slide number (in parentheses), England Finder coordinates, and dimension(s) of figured specimen.

All slides containing holotype material are housed in the palynology collection of the Royal Ontario Museum, Toronto, Ontario.

Division PYRRHOPHYTA Pascher, 1914

Class DINOPHYCEAE Fritsch, 1929

Order PERIDINIALES Haeckel, 1894

Genus APTEODINIUM Eisenack, 1958 emend. Lucas-Clark, 1987

Apteodinium spiridoides Benedek, 1972 emend. Benedek and Sarjeant, 1981.

(Pl. 9, Fig. 19)

Remarks. A. spiridoides (formerly Emslandia spiridoides (Benedek) Benedek and Sarjeant, 1981, see Lucas-Clark, 1987) has a recorded range of late Eocene (Costa and Downie, 1979) to early or middle Miocene, although it has also been recorded from the early Eocene of Maryland, U.S. (as Apteodinium sp. in Goodman, 1979). There are a number of lower Miocene records (Stover, 1977; Ioakim, 1979; Brown and Downie, 1985; as A. cf. spiridoides in Manum 1976; as Apteodinium sp. B, in Williams and Bujak, 1977b; Costa, 1980; Edwards, 1986; Powell, 1988a; Manum et al., in press). The species was recorded from the upper lower Miocene (nannofossil Zone NN4) from the North Sea (Ioakim, 1979), and its last occurrence in both the Norwegian Sea (Manum et al., in press) and offshore eastern Canada (Williams and Bujak, 1977b) coincides with the postulated lower/middle Miocene boundary. $A$. spiridoides also occurs in presumed lower middle Miocene sediments of Maryland, U.S. (reported from beds 4 through 9 of the Plum Point Member, Calvert Formation, which have been correlated by Andrews [1988] using diatom stratigraphy, to the lower part of nannofossil Zone NN5 [L. de Verteuil, pers. comm. to M.J.H., 1988]). This species has also been recorded by Piasecki (1980) from Denmark (we agree with Lucas-Clark, 1987, that the holotype of A. tectatum Piasecki 1980 is a subjective junior synonym of $A$. spiridoides, although we note that the paratype, Pl. 2, Figs. 1-3 in Piasecki [1980] has a noncavernous periphragm and thus does not resemble $A$. spiridoides), where it occurs in sediments of lower middle Miocene or possibly late early Miocene age (see discussion of age in "Other Miocene Palynological Studies" section, this chapter). Herngreen (1987) reported, without illustration, $A$. tectatum from the putative middle Miocene of his Zone I in the Broeksittard borehole of southeastern Holland. Haq et al. (1987) correlated the highest occurrence of $A$. spiridoides to the middle of nannofossil Zone NN5, and planktonic foraminiferal Zone N10 (early middle Miocene).

\section{Apteodinium sp. 1 \\ (Pl. 12, Figs. 3,4)}

Remarks. Spherical (sometimes slightly pear-shaped) autocyst, lacking an apical boss, and with a granulate wall surface. Paracingulum faintly indicated by low obtuse ridges, although parasutures were rarely seen elsewhere. The archeopyle is large and precingular. Maximum diameter, 58(68.3)74 $\mu \mathrm{m}$, from 11 measurements.

\section{Genus BATIACASPHAERA Drugg, 1970}

\section{Batiacasphaera sp. cf. B. baculata Drugg, 1970}

$$
\text { (Pl. 9, Figs. 16-18) }
$$

Remarks. Cysts spherical with a smooth to faintly granulate wall surface. Baculae cover entire surface of cyst, although these have a slightly irregular (penitabular?) distribution. Baculae are 3 to $4 \mu \mathrm{m}$ in length, cylindrical to slightly tapering, distally rounded to truncated, or bluntly terminated (Sample 105-645E-76R-2, 134-137 cm) or truncated and slightly expanded distally (Sample 105-645E-78R, CC). Archeopyle apical, with an angular principal suture. Operculum free. Maximum body diameter, $44(49.4) 57 \mu \mathrm{m}$, from 12 measurements.

B. baculata (as described by Drugg, 1970 from the upper Eocene of the U.S. Gulf Coast) differs from the Site 645 specimens in having smaller $(2.0-2.5 \mu \mathrm{m})$ baculae. Two specimens figured as $B$. baculata by 
Manum et al. (in press) appear similar to the Baffin Bay specimens (though the Norwegian specimens may also have a finer baculate ornament). Manum et al. (in press) recorded $B$. baculata only from the early Miocene of ODP Site 643, Norwegian Sea (Manum et al., in press), but it possibly extends into the latest Oligocene at DSDP Site 338 (based on an unillustrated record of "cf. B. baculata," in Manum, 1976).

\section{Batiacasphaera gemmata $\mathrm{n} . \mathrm{sp}$.}

$$
\text { (Pl. 9, Figs. 1-4) }
$$

Holotype (Pl. 9, Figs. 1-3). Sample 105-645E-78R-CC (4) J15/3. Early Miocene.

Derivation of name. Latin gemmatus, budded; with reference to the gemmate ornament that characterizes this species.

Diagnosis. Cyst spherical and has a hyaline autophragm with smooth to faintly scabrate surface bearing gemmae of variable size that are irregularly and sparsely distributed over all, or most of, the surface. Archeopyle apical Type (4A), having a moderately angular principal suture. Accessory sutures may be developed. Operculum free.

Dimensions. Holotype: Cyst diameter (excluding ornament), $34 \mu \mathrm{m}$, maximum diameter of gemmae, $2.8 \mu \mathrm{m}$. Range in cyst diameter, 30 (34.5) $40 \mu \mathrm{m}$. Range in diameter of largest gemma, 1.4-3.0 m. Wall thickness, about $1 \mu \mathrm{m}$. Ten specimens were measured.

Description. The autophragm, including gemmae, is hyaline and does not take up the safranin-O used to stain residues in this study. Individual specimens bear a range of gemma sizes, often down to $0.5 \mu \mathrm{m}$ or less. Distribution of gemmae is irregular and rather sparse, as illustrated specimens (Pl. 9, Figs. 1-4) demonstrate, although this does not appear to reflect paratabulation. Gemmae may be loosely clustered and have an average density from up to seven or eight gemmae (of approximately 2 $\mu \mathrm{m}$ diameter) per $25 \mu \mathrm{m}^{2}$, although typically averages one to three per $25 \mu \mathrm{m}^{2}$, as for the holotype. No features reflecting paratabulation were observed other than the archeopyle.

Remarks. No other species of Batiacasphaera is known to possess gemmate ornament.

\section{Batiacasphaera micropapillata Stover, 1977 "complex"}

(Pl. 9, Figs. 11-13)

Remarks. Specimens assigned to this complex of morphotypes are small (around $29-41 \mu \mathrm{m}$ in diameter), thin-walled, and usually somewhat crumpled. Surface ornament varies from microreticulate, punctate, microrugulate, to faintly granulate. The archeopyle is interpreted to be apical, having a principal suture with low angularity and no accessory sutures. The operculum is free. Some specimens in this group can be assigned to $B$. micropapillata. However, the archeopyle type could not be determined in many cases, and given the variable nature of the ornament, this group might make up more than a single species. This group may be partly conspecific, with specimens referred to "Batiacasphaera/Cerebrocysta group A" in Head et al. (b, this volume) from the late Miocene of Hole 646B in the Labrador Sea, although the latter may be more heterogeneous; and with specimens referred to Batiacacysta micropapillata sensu lato in Head and Norris (this volume), from the middle Eocene through lower Oligocene (nannofossil Zones NP16 through NP22) of Hole 647A in the Labrador Sea. The stratigraphic distribution of $B$. micropapillata is discussed (under "Batiacasphaera/Cerebrocysta group A") in Head et al., (a, this volume).

\section{Batiacasphaera sphaerica Stover 1977}

$$
\text { (Pl. 9, Figs. 6,7) }
$$

Remarks. Specimens have a punctate to microreticulate surface, an angular principal archeopyle suture. The wall is thicker (up to $1.3 \mu \mathrm{m}$ ) than for the B. micropapillata complex, and less variation occurs in the surface ornament. Specimens were recorded rarely in this study, although some specimens may have been included with the $B$. micropapillata complex. B. sphaerica has a known range of early to late Miocene (Stover, 1977; Edwards, 1984b, 1986; Manum et al., in press).

\section{Batiacasphaera? sp. 1}

$$
\text { (Pl. 9, Fig. 14) }
$$

Remarks. Cysts small, spherical, and thin-walled, with apical? archeopyle. Ornament consists of short, blunt hairs. Specimens are smaller than B. hirsuta Stover, 1977 and have a less dense covering of hairs, although they may be similar to $B$. hirsuta sensu Edwards, 1984a (PI. 2,
Fig. 5; also illustrated in Edwards, 1986, Pl. 1, Fig. 1) from the upper Oligocene of Virginia and may be conspecific with $B$. sp. cf. $B$. hirsuta recorded from the middle Eocene (nannofossil Zone NP16) of Hole 647A in the Labrador Sea (Head and Norris, this volume).

Genus CANNOSPHAEROPSIS Wetzel, 1933 emend. Williams and Downie in Davey et al., 1966

Cannosphaeropsis? sp. 1

(Pl. 4, Figs. 1,2)

Remarks. Central body spherical and smooth-walled. Processes are solid and at least some stems have $\mathrm{Y}$ cross sections, indicating a gonal position. Processes expand distally to form wide, smooth membranous platforms that may link with adjacent processes and may form broad, irregular, ribbonlike connections. A single specimen was found.

\section{Genus CEREBROCYSTA Bujak, 1980}

\section{Cerebrocysta? sp. 1}

(Pl. 12, Figs. 7,8)

Remarks. Cyst spherical, with a thin endophragm and thicker (2.0 $\mu \mathrm{m})$ periphragm composed of high sinuous crests (possibly closely appressed folds) that produce a vermiculate/reticulate pattern. Archeopyle possibly precingular. A single specimen was observed.

Genus CORDOSPAHERIDIUM Eisenack, 1963 emend. Davey, 1969

\section{Cordosphaeridium cantharellum (Brosius, 1963) Gocht, 1969}

Remarks. Isolated specimens were recorded, and some or all may be reworked. This species has a last occurrence in the early Miocene of the North Sea (Ioakim, 1979; Costa, 1980); central Europe (Hochuli, 1978), southern Europe (Powell, 1986a,b), offshore eastern Canada (Williams and Bujak, 1977b) and Norwegian Sea area (Manum, 1976; Manum et al., in press), and occurs in the early Miocene of offshore eastern U.S. (C. dissimilis foraminiferal zone in Stover, 1977). Presently available records of this species suggest a last appearance in the late early Miocene (nannofossil Zone NN4; Ioakim, 1979). C. cf. cantharellum has a last occurrence in the early middle Miocene of Japan (Matsuoka et al., 1987).

\section{Cordosphaeridium minimum sensu Benedek and Sarjeant, 1981}

$$
\text { (Pl. 6, Fig. 4) }
$$

Remarks. Central body spherical to somewhat ellipsoidal and thinwalled with a smooth or scabrate surface. Processes are of fairly constant length, buccinate with finely fibrous stems, variably flared distally, and often developing thin membranous expansions having entire irregular margins. Archeopyle determined as apical on a few specimens, but generally not seen. Maximum central body diameter, 18 (21.1) $23 \mu \mathrm{m}$; maximum total cyst diameter, 37 (40.6) $44 \mu \mathrm{m}$. Eight specimens were measured.

Specimens recovered from Site 645 closely resemble the specimen figured as C. minimum by Benedek and Sarjeant (1981, Fig. 10, No. 2) from the middle Oligocene of Germany, which does not appear to have the coarsely fibrous to areolate body surface described by Morgenroth (1966) for C.(?) minimum (Morgenroth) Benedek, 1972 from the early Eocene of Germany. Benedek and Sarjeant (1981) also noted that their specimens apparently have apical archeopyles. Araneosphaera stephanophora is similar to C. minimum sensu Benedek and Sarjeant (1981) but differs in having processes that are distally united.

C.(?) minimum has been recorded from the upper Paleocene to Miocene (Morgenroth, 1966; Benedek, 1972; Auffret and Gruas-Cavagnetto, 1975; De Coninck, 1977; Williams and Bujak, 1977b; Barss et al., 1979; Ioakim, 1979; Chateauneuf, 1980; Liengjarern et al., 1980; Piasecki, 1980; Bujak et al, 1980; Sarjeant, 1981; Benedek and Sarjeant, 1981; Brown and Downie, 1984, 1985; Fechner and Mohr, 1986, 1988; Powell, 1986a, 1986b; Herngreen, 1987; Head and Norris, this volume). A record of $C$.(?) minimum from the British Southwestern Approaches was dated as late? Pliocene or older (based on dinoflagellate markers by Powell, 1988a) or middle Miocene (based on foraminifer markers, Zones N11-N12, by Evans and Hughes, 1984). The stratigraphic range of $C$. minimum sensu Benedek and Sarjeant (1981) is not clearly known as a result of taxonomic uncertainties, although most Miocene and Oligocene records may pertain to this taxon. The species may have its highest 
appearance in the lower upper Miocene (lower nannofossil Zone NN11) of the Goban Spur (as cf. C. minimum in Brown and Downie, 1985) and also extends into the putative late Miocene of Denmark (Piasecki, 1980).

\section{Genus CRIBROPERIDINIUM Neale and Sarjeant, 1962 emend. Helenes, 1984 \\ Cribroperidinium tenuitabulatum (Gerlach, 1961) Helenes, 1984} (Pl. 10, Figs. 5,6)

Remarks. Specimens from Site 645 have a finely granulate autophragm surface with low obtuse parasutural ridges that are pronounced around the cingulum and incompletely expressed elsewhere. Faint accessory sutural ridges may also occur in places (see comment in Lentin and Williams, 1985, p. 81 concerning the emendation of this species by Sarjeant, 1984). C. tenuitabulatum (originally described from Oligocene sediments) was recorded from early to middle Miocene sediments by Corradini, 1978; Bujak and Matsuoka, 1986a; Duffield and Stein, 1986; LeNoir and Hart, 1986; El-Beialy, 1988a; and Manum et al., in press. This species may have its range top in the early middle Miocene (e.g., Duffield and Stein, 1986, planktonic foraminiferal Zone N10; Matsuoka et al., 1987) and undifferentiated middle Miocene (El-Beialy, 1988a), although in the Norwegian Sea this species has a last observed occurrence within the late? early Miocene (Manum et al., in press).

Genus CRISTADINIUM Head et al. (b, this volume)

Cristadinium cristatoserratum Head et al. (b, this volume) (Pl. 7, Fig. 11)

Remarks. This species, recovered rarely from dinocyst assemblage Zone BB5 of this study, was recorded from upper Miocene sediments (nannofossil Zones NN10 and NN11) from ODP Hole 646B in the Labrador Sea (Head et al., a, this volume).

Cristadinium sp., aff. C. cristatoserratum Head et al. (b, this volume) (Pl. 7, Fig. 12)

Remarks. A single specimen was found that differs from C. cristatoserratum in having crests on both the epicyst and hypocyst. Crest tops are finely indented in places (as for $C$. sp. 1), rather than entirely serrated (as for $C$. cristatoserratum).

\section{Cristadinium sp. 1}

(Pl. 7, Fig. 9)

Remarks. Autophragm pale to medium brown, with smooth surface and parasutural crests on the lateral margins of the epicyst $(2.8 \mu \mathrm{m}$ high), paracingular margins ( $3.0 \mu \mathrm{m}$ high), and lateral margins of the hypocyst. Crests on the hypocyst extend around either horn (where they attain a maximum height of $7 \mu \mathrm{m}$ ) and along the antapical margin, although apparently do not quite meet at the mid-ventral line. All crests are straight, topped with closely spaced, rounded indentations that are about $1 \mu \mathrm{m}$ deep. Paracingulum is planar. A single specimen was found.

Cristadinium sp. 2

(Pl. 7, Fig. 10)

Remarks. Autophragm pale brown with a very faintly granulate surface. Parasutural crests with serrated to indented (by about $1 \mu \mathrm{m}$ ) tops occur on paracingular margins (up to $2 \mu \mathrm{m}$ high) and on epicyst (up to $2 \mu \mathrm{m}$ high), where they are possibly confined to lateral margins. The hypocyst has straight topped crests (about $2 \mu \mathrm{m}$ high, although reaching a maximum of $3.5 \mu \mathrm{m}$ at horn tips) on both lateral and antapical margins and a pair of similar crests that extend from the tips of each antapical horn, toward the paracingulum. The paracingulum is planar. A single specimen was found.

\section{Genus DINOPTERYGIUM Deflandre, 1935 emend. Stover and Evitt, 1978}

Dinopterygium cladoides Deflandre, 1935 sensu Morgenroth, 1966 (Pl. 6, Fig. 3)

Remarks. A single, well-preserved specimen was found. Characteristic features of this taxon include the development of faint darkened parasutural lines on the endophragm that may be interrupted by perforations (as in Pl. 6, Fig. 3; see also Williams and Brideaux, 1975, Pl. 17, Fig. 1) and the presence of intratabular tubules that support a thin periphragm. Parasutural crests are absent or develop as low folds of periphragm, in contrast to the more pronounced, solid? crests that are higher gonally than elsewhere, in the Cretaceous species $D$. cladoides Deflandre, 1935 (as indicated from Deflandre's, 1935 line drawing of the holotype).

This species has been recorded both as $D$. cladoides and as $D$. cladoides sensu Morgenroth in the Tertiary literature. It has been recorded from the Eocene of the following localities: southern England (Bujak et al., 1980; Islam, 1983a, 1983b, 1984), Belgium (De Coninck, 1975, 1977, 1980; De Coninck et al., 1983), Germany (Morgenroth, 1966; Fechner and Mohr, 1988), eastern U.S. (Goodman, 1979; Edwards, 1984b), off shore eastern Canada (Williams and Bujak, 1977b; Barss et al., 1979), Northeast Atlantic (Brown and Downie, 1984, 1985), Poland (Van Couvering et al., 1980), Norwegian Sea (Manum et al., in press), Labrador Sea (Head and Norris, this volume), and the upper Eocene or lower Oligocene of Spitsbergen (M.J.H., unpubl. data). This species has been recorded from the Oligocene of the following localities: Germany (Benedek, 1972), offshore eastern Canada (Williams and Bujak, 1977b; Barss et al., 1979), Norwegian Sea (Manum et al., in press), and ODP Site 647, Labrador Sea (Head and Norris, this volume). D. cladoides sensu Morgenroth has a highest occurrence in the lower Miocene of the Norwegian Sea (Manum et al., in press), which compares with its highest occurrence within the lower Miocene Baffin Bay (this study); but it has also been recorded, without illustration, from the upper Miocene through upper Pliocene of Belgium and The Netherlands (Benedek, 1980).

D. cladoides sensu Morgenroth has a range base in the lower Eocene (nannofossil Zone NP12, Bujak et al., 1980, correlated from Aubry, 1985; upper Zone NP12, Head and Norris, this volume; or possibly into Zone NP11, De Coninck et al., 1983, correlated from Aubry, 1985). We consider its range top to be in the lower Miocene (Manum et al., in press; this study), with higher records pending confirmation. This contrasts with the much shorter range of lower through middle Eocene (nannofossil zones, upper NP12 through NP17) given by Williams and Bujak (1985).

\section{Genus DISTATODINIUM Eaton, 1976}

Remarks. In 1976, Eaton erected the genus Distatodinium, with a new species, $D$. craterum as its type, and transferred to this genus a number of species, including $D$. paradoxum (previously Tanyosphaeridium paradoxum (Brosius) Gocht). Sung Z-c. et al., (the authors of Jiabo, ${ }^{1} 1978$ ) were evidently unaware of the genus Distatodinium Eaton, 1976, when they erected the genus Bipolaribucina, and implicitly chose T. paradoxum (Brosius) as its type. Chen et al. (1988, p. 7) observed that the generic description of Bipolaribucina does not closely agree with the morphology of its type and rejected the transfer of $T$. paradoxum by Sung Z-c. et al. (1978) to Bipolaribucina in favor of retaining it in Distatodinium Eaton, 1976 (its previous assignment). Bipolaribucina thus became a junior synonym of Distatodinium (Chen et al., 1988), and the remaining species of Bipolaribucina were transferred by Chen et al. (1988) to Impletosphaeridium Morgenroth, 1966.

\section{Distatodinium paradoxum (Brosius, 1963) Eaton, 1976 sensu lato}

$$
\text { (Pl. 3, Figs. 1-5) }
$$

Remarks. Specimens here assigned to $D$. paradoxum sensu lato show variability in process stem width and degree of distal fimbriation. Some may be referable to $D$. craterum. Specimens that may be broadly similar to our $D$. paradoxum s.l. (including $D$. craterum, but excluding $D$. paradoxum sensu Gocht, see discussion in Head and Norris, this volume) have been recorded from Europe (Scherer, 1961; Brosius, 1963; Benedek, 1972; Eaton, 1976; Benedek and Müller, 1976; Hochuli, 1978; Piasecki, 1980; Bujak et al., 1980; Chateauneuf, 1980; Van Couvering et al., 1981; Michoux, 1985; Powell, 1986a, 1986b, 1988a), the North Atlantic (Costa and Downie, 1979-as "Distatodinium spp."; Brown and Downie, 1985) the Norwegian-Greenland Sea (Manum, 1976-as "Tanyosphaeridium cf. sp A." and Manum et al, in press-as " $D$. paradoxum") offshore eastern Canada (Williams and Brideaux, 1975, and

${ }^{1}$ Etymological note: "Jiabo" is a collective name for the authors Sung Zhichen, He Cheng-quan, Qian Ze-Shu et al., and derives from "Jia," the root word in Chinese for dinoflagellate and "Bo," the first syllable of Bohai. 
Williams and Bujak, 1977b-both as "Tanyosphaeridium sp. A"; Williams and Bujak, 1977a), Labrador Sea (as D. sp., cf. D. craterum in Head and Norris, this volume), North and West Pacific (Bujak and Matsuoka, 1986a), and Korea (Yun, H., 1988). These records indicate an FA in the middle Eocene, equivalent to nannofossil Zone NP16 (Eaton, 1976; Bujak et al, 1980; Chateauneuf, 1980)--see Aubry (1985) and Aubry et al. (1986); and Lutetian (Michoux, 1985).

D. paradoxum has a highest recorded occurrence within the lower Miocene in northwest Italy (Powell, 1986b); eastern North Atlantic (Rockall Plateau, in Costa and Downie, 1979; Goban Spur, in Brown and Downie 1985; British Southwestern Approaches, in Powell, 1988a); and $\mathrm{Haq}$ et al. (1987) proposed a range top of upper lower Miocene (within nannofossil Zone NN3 and planktonic foraminiferal Zone N6) for this species. Last occurrences of $D$. paradoxum are apparently diachronous, however, as these occur within the putative early middle Miocene of the Norwegian Sea (Manum, 1976; Manum et al., in press) and Denmark (Piasecki, 1980). Williams and Bujak (1977a, 1977b; offshore eastern Canada) and Bujak and Matsuoka (1986a; for the northern and western Pacific) also recorded last occurrences within the early part of the middle Miocene, although these ages are not precisely constrained. The LA of $D$. paradoxum in the early middle Miocene at Site 645 is thus approximately correlative with this event in the Norwegian Sea, Denmark?, offshore eastern Canada, and northern and western Pacific.

Williams and Bukak (1976a) suggested a latitudinal control for the distribution of $D$. paradoxum during the Oligocene, based on its absence from several low-latitude sites. D. paradoxum s.l. has since been recorded frequently from Oligocene to lower Miocene mid- to high-latitude northern sites (see records above), although this taxon was also recorded in Paleogene and early Neogene sediments of the Gulf of Mexico (J.H. Wrenn, pers. comm. to M.J.H., 1988). More studies of low-latitude sites will be required to determine whether latitudinal control was responsible for the distribution of $D$. paradoxum s.l.

\section{Genus EVITTOSPHAERULA Manum, 1979 \\ Evittosphaerula paratabulata Manum, 1979 \\ (Pl. 5, Fig. 13)}

Remarks. Only two specimens of Evittosphaerula paratabulata were recorded in this study. This species ranges from lower Oligocene through middle Miocene in DSDP Hole 338, Norwegian Sea (as "Problematicum 1," Manum, 1976; 1979) and was restricted to a short interval $(E$. paratabulata Zone) within the early Miocene of ODP Site 643, Norwegian Sea (Manum et al., in press). E. paratabulata has also been recorded from Miocene sediments of the Beaufort Sea. An age assignment of late middle to late Miocene was proposed for these on the basis of dinoflagellate evidence (Bujak and Davies, 1981; Bujak and Davies, in Dixon et al., 1984) and an early to middle Miocene age proposed on the basis of foraminiferal evidence (McNeil in Dixon et al., 1984). We interpret the age of the dinoflagellate assemblage described by Bujak and Davies (in Dixon et al., 1984) as being equally consistent with an early to middle Miocene age, as suggested from foraminifer markers. Thus, the presently observed range for $E$. paratabulata may be restricted to the lower Oligocene to middle Miocene, which is compatible with its lower Miocene occurrence at ODP Hole 645E. Bujak and Davies (1981, and in Dixon et al., 1984) considered E. paratabulata a probable coldwater species.

\section{Genus HABIBACYSTA Head et al. (b, this volume)}

Habibacysta tectata Head et al. (b, this volume) (Pl. 9, Fig. 15)

Remarks. Habibacysta tectata was recorded from throughout the late Miocene of ODP Site 646B, Labrador Sea (Head et al., a,b, this volume) and occurs persistently through Zones BB3 to BB5 of this study. Its geographic distribution suggests a cool-water tolerance, and its FA may prove a useful regional indicator for the early middle Miocene.

\section{Genus HETERAULACACYSTA Drugg and Loeblich, 1967 emend. Bujak, 1980 \\ Heteraulacacysta sp. A of Costa and Downie, 1979 (Pl. 6, Fig. 5)}

Remarks. This species is characterized by minute intratabular tubules or solid rods that support a smooth (faintly granulate on a few specimens) thin periphragm. Crests are up to $8 \mu \mathrm{m}$ high on the paracingulum, but elsewhere they are lower and may be low folds of periphragm. Maximum overall diameter is 68 (79.7) $97 \mu \mathrm{m}$, based on 11 specimens. This species is larger than $D$. cladoides sensu Morgenroth and has a finer pattern of intratabular tubules or rods. It was recorded from the late Oligocene of the Rockall Plateau (Costa and Downie, 1979) and from the middle Eocene of the North Sea (as H. campanula in Ioanides, 1979).

\section{Genus HYSTRICHOSPHAEROPSIS Deflandre, 1935 emend. Sarjeant, 1982}

\section{Hystrichosphaeropsis sp. cf. H. obscura Habib, 1972}

Remarks. A single torn specimen was recorded in this study, from Sample 105-645E-75R-4, 15-18 cm, which occurs in the lower part of dinocyst assemblage Zone BB2. The specimen (not illustrated) is bicavate, without processes. The endocyst is spherical (diameter, $64 \mu \mathrm{m}$ ) without parasutural markings, has a finely granulate/micropunctate surface, and the wall is $1.2 \mu \mathrm{m}$ thick. The pericyst is $112 \mu \mathrm{m}$ long, thinner than the endocyst, has a scabrate surface, and is somewhat crumpled. The paracingulum is expressed by low crests on the dorsal area. The parasulcus is weakly indicated by low folds or crests, but elsewhere, paratabulation is absent or perhaps weakly expressed.

Haq et al. (1987) proposed a range top of uppermost lower Pliocene (nannofossil Zone NN15) for $H$. obscura, although El-Beialy (1988a) noted that it has a highest reported occurrence in the middle Miocene of the following areas: Germany (as Hystrichosphaera ovum, in Gerlach, 1961); offshore eastern Canada (Williams, 1975; Williams and Bujak, 1977); Norwegian-Greenland Sea (Manum, 1976); and the Bay of Biscay, (Harland, 1979). In the Nile Delta, Egypt, it persists through the middle Miocene (El-Beialy, 1988a, 1988b) and into the lower upper Miocene (El-Beialy, 1988b). Other Miocene occurrences have been reported by Habib (1971, as H. sp., cf. H. ovum), Jan du Chêne (1977), Harland (1978), Corradini (1978, as Rottnestia borussica), Williams (1978), Piasecki (1980), Edwards (1984b), Bujak and Matsuoka (1986a), LeNoir and Hart (1986), Powell (1986a, 1986b, and references therein; 1988a), Wrenn and Kokinos (1986), Wrenn and Satchell (1988), and Manum et al. (in press). $H$. sp. cf. $H$. obscura was also recorded from Miocene sediments by Powell (1988a).

Haq et al. (1987) considered $H$. obscura to have a range base in the middle lower Miocene (nannofossil zone, top NN1), although Powell (1986a) recorded this species from slightly older sediments (latest Oligocene, planktonic foraminiferal zone, upper P22) from northwest Italy. Powell $(1986 \mathrm{a}$, p. 90, 94), upon a review of the literature, nevertheless suggested that there was no reliable evidence for an earlier appearance of this species. Thus, one may doubt an unillustrated middle Eocene record from the Goban Spur (nannofossil Zone NP15) by Brown and Downie (1985)

Wrenn and Kokinos (1986) considered $H$. obscura to be an outer neritic to oceanic species in their environmental model of Neogene dinocyst distribution in temperate seas. Bujak and Matsuoka (1986a) listed $H$. obscura as one of several species that disappeared in the early middle Miocene of Japan, possibly in response to the change from warm to cold water in that area. A single specimen questionably referred to this species was recorded from the early Miocene at Site 645 . Both the coolwater temperature and absence of fully marine conditions might be responsible for the rarity, or absence, of $H$. obscura at Site 645, although cool temperatures are a more likely cause, judging by its apparent absence from oceanic late Miocene sediments at Site 646 (Head et al., a, this volume).

Genus IMPAGIDINIUM Stover and Evitt, 1978

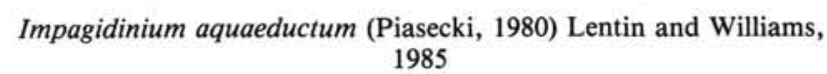

(Pl. 10, Fig. 8)

Remarks. Impagidinium aquaeductum has a wide distribution within the North Atlantic and adjacent areas, although it is apparently absent from Pacific assemblages. The species has been recorded from Europe (Pl. 2, Fig. 4, in Baltes, 1967; and as "Nematosphaeropsis balcombiana" in Baltes, 1969; Harland, 1978; Piasecki, 1980; Powell, 1986b; Herngreen, 1987), offshore northwest Africa, DSDP Site 369 (Stein et al., 1987); the Norwegian-Greenland Sea (Manum et al., in press, and as "Leptodinium sp. V" in Manum, 1976) and the North Atlantic (Costa and Downie, 1979; Edwards, 1984b; Brown and Downie, 1985; 
although probably not "N.(?) aquaeducta" of Mudie, 1987). Harland (1978) suggested a range of middle Miocene to Pliocene, based on northwest European records of $I$. aquaeductum, but we prefer the lower range top of middle upper Miocene (correlated with nannofossil zone, upper NN10) as proposed by Haq et al. (1987).

The earliest well-constrained FA of I. aquaeductum is at DSDP Site 406 of the Rockall Plateau (Costa and Downie,1979), recorded near the base of nannofossil Zone NN5 (Müller, 1979) and within planktonic foraminiferal $P$. glomerosa Zone (Krasheninnikova, 1979), thus placing this FA within the middle Miocene and near the early/middle Miocene boundary (see also Costa and Müller, 1978). Edwards (1984b) also recorded an earliest appearance for $I$. aquaeductum from nannofossil Zone NN5 (Backman, 1984, p. 414), from DSDP Hole 553A, from the Rockall Plateau. From DSDP Hole 548A, of the Goban Spur, Brown and Downie (1985) recorded a first occurrence of I. aquaeductum from an undifferentiated nannofossil Zone NN5-NN6 interval (Müller, 1985) and planktonic foraminiferal Zone N10/12 (Snyder and Waters, 1985). From northwest Italy, Powell (1986b) reported a first occurrence of $I$. aquaeductum from the plantonic foraminiferal upper Zone N10 (middle middle Miocene). The FA of $I$. aquaeductum from the Norwegian Sea (DSDP Sites 338, as "Leptodinium sp. V" in Manum, 1976; ODP Site 643 , Manum et al., in press) was placed within the middle Miocene, but above its base, although ages are not well constrained for these sites. The FA of I. aquaeductum may be a good marker for the early/middle Miocene boundary in some sites (Brown and Downie, 1985, p. 644). However, evidence from both the literature reviewed above and from Site 645 suggest that this datum is diachronous (some possible reasons for which are discussed in Powell, 1986b, p. 122), although at several sites it is approximately confined to the earlier half of the middle Miocene. To our knowledge, there is no evidence that supports an Oligocene range base, indicated for this species by Williams and Bujak (1985). In summary, we propose an early middle (nannofossil Zone NN5) through middle upper Miocene (nannofossil zone, upper NN10) range for $I$. aquaeductum.

\section{Impagidinium maculatum (Cookson and Eisenack, 1961) Stover and Evitt, 1978 sensu Manum et al. (in press)}

\section{(Pl. 10, Fig. 9)}

Remarks. Specimens assigned to Impagidinium maculatum sensu Manum et al. (in press) are spherical to subspherical and have an overall diameter of 51 to $80 \mu \mathrm{m}$ (average, $65 \mu \mathrm{m}$ ) from nine measurements. Parasutural crests are low (1.5-3.0 $\mu \mathrm{m})$, straight-topped, and have a smooth surface. The ventral area was not clearly observed but sulcal paratabulation is probably poorly expressed. The wall surface is covered by low, discontinuous ridges that often may coalesce to form a coarse reticulum. This contrasts with the discrete granules present on $I$. maculatum Cookson and Eisenack, 1961b. I. maculatum sensu Manum et al. (in press) was recorded from lower through upper Miocene sediments of the Norwegian Sea (Manum et al., in press).

\section{Impagidinium spp. 1 through 7}

(Pl. 11, Figs. 1-16)

Most Impagidinium species were not determined in detail owing to their low abundance at Site 645; thus, this group is provisionally subdivided. Several species recorded here are elongate in outline and compare superficially with several species of Impagidinium described from the Norwegian Sea by Manum (1976, as Leptodinium spp. 2 through 4) and Manum et al. (in press, as Impagidinium sp. 1).

\section{Genus IMPLETOSPHAERIDIUM Morgenroth, 1966}

\section{Impletosphaeridium prolatum $\mathrm{n} . \mathrm{sp}$.}

$$
\text { (Pl. 6, Fig. 1) }
$$

Holotype (Pl. 6, Fig. 1). Sample 105-645E-65R-4, 94-96 cm, (5) V31/2; middle? Miocene.

Derivation of name. Latin prolatus, extended, enlarged; with reference to the prolate, ovoidal shape of the central body.

Diagnosis. Central body is ovoidal, composed of two thin, closely appressed wall layers and possessing a smooth surface. Processes are narrow, nontapering, solid, unbranched, of equal length, and have expanded distal tips. Process distribution fairly regular and apparently nontabular.
Dimensions. Holotype: central body length, $31 \mu \mathrm{m}$; process length, $10 \mu \mathrm{m}$. Range in central body length, 28 (33.4) $38 \mu \mathrm{m}$. Range in process length, 5 (8.1) $12 \mu \mathrm{m}$. Fourteen specimens were measured.

Description. Periphragm usually appressed to endophragm but may be slightly wrinkled between process bases. Expanded process tips are about $1 \mu \mathrm{m}$ wide and form irregular, flattened platforms. An excystment aperture was not identified with certainty, but rupturing of the cyst body in the apical/subapical region was noted in a few specimens. A low rounded, thickened body, yellow in color and with a maximum length of 4 to $5 \mu \mathrm{m}$, was seen in several specimens, including the holotype (Pl. 6, Fig. 1). It is unclear whether this feature is primary (as an omphalus) or preservational.

Remarks. This species appears somewhat similar to Impletosphaeridium ligospinosum (De Coninck) Islam, 1983 from the early Eocene of Belgium. However, the latter has a somewhat smaller central body (20$25 \mu \mathrm{m})$ and the precise nature of its processes cannot be determined from De Coninck's illustrations. Impletosphaeridium insolitum Eaton, 1976 from the middle Eocene has a spherical to subspherical central body (15-24 $\mu \mathrm{m}$ in diameter) and specimens typically possess both simple and bifurcate processes. Dioxya(?) pignerata Norris, 1986, recorded from the Paleogene of the Mackenzie Delta region of Canada (Norris, 1986; and as "Dinoflagellate sp. J-7" in Staplin, 1976) differs from $I$. prolatum n. sp. in its larger size (body length $=45$ to $83 \mu \mathrm{m}$ ) and apparent presence of a combination AI archeopyle (Norris, 1986). A specimen figured by Dietrich et al. (1989, Pl. 1, Fig. 3) as Dioxya(?) pignerata, from the lower to middle Eocene of the western Beaufort Sea, is smaller (body length $=38 \mu \mathrm{m}$, measured from the illustration) than the range recorded for $D$.(?) pignerata by Norris (1986). This specimen, as far as can be judged from the illustration, might be conspecific with $I$. prolatum $\mathrm{n}$. $\mathrm{sp}$.

\section{Impletosphaeridium sp. 1}

(Pl. 3, Figs. 11,12)

Remarks. Central body spherical to subspherical, single layered (or possibly two closely appressed layers), with a smooth surface. Processes solid branched and tapering. Complex branching occurs within the distal quarter of the process length, although some simple branching may occur within the distal half. Processes are not linked proximally and are fairly evenly distributed and nontabular. Maximum central body diameter, 36 (39.4) $43 \mu \mathrm{m}$, process length, 13 (15.9) $18 \mu \mathrm{m}$. Eleven specimens were measured.

\section{Genus INVERTOCYSTA Edwards, 1984}

Invertocysta tabulata Edwards, 1984

(Pl. 6, Fig. 6)

Remarks. Specimens of $I$. tabulata were encountered only rarely in this study. The species has a lowest recorded occurrence in the upper Oligocene (as "Forma A [ = "Thalassiphora delicata"]") of the Rockall Plateau (Costa and Downie, 1979, nannofossil Zone NP25). It has highest recorded occurrences in the upper Miocene of the following areas: Goban Spur (Edwards, 1984b, nannofossil zone, upper NN11, correlated from Backman, 1984); central and northern North Atlantic (grouped with Invertocysta spp., in Mudie, 1987); northwest Italy (Powell, 1986c, planktonic foraminiferal Zone N17, Messinian); ODP Site 502, western Caribbean Sea (Wrenn, pers. comm. to M.J.H., 1987, nannofossil Zone $\mathrm{CN} 9 \mathrm{~b} \equiv$ upper NN11); and in the upper Pliocene of the Gulf of Mexico (Wrenn and Kokinos, 1986, planktonic foraminiferal Zone N21; and as I. cf. tabulata in the Pleistocene, Zone N22).

I. tabulata was considered an outer neritic to oceanic species by Wrenn and Kokinos (1986).

\section{Genus LABYRINTHODINIUM Piasecki, 1980}

\section{Labyrinthodinium truncatum Piasecki, 1980}

$$
\text { (PI. 10, Fig. 1) }
$$

Remarks. L. truncatum has a range of upper? lower Miocene through lower upper Miocene. Neogene records of this species are given in Head et al.(a, this volume) and lowest reported occurrences are discussed below.

Piasecki (1980) used the lowest occurrence of $L$. truncatum to define the base of his lowermost zone (the L. truncatum Zone) from the Miocene Hodde Formation of Denmark, for which he accepted a middle Miocene age based on molluscan and dinoflagellate evidence. The age 
of the Hodde Formation is not precisely established, however, and the lower part might be of late early Miocene age, based on the benthic foraminiferal correlation of King (1983) and on a reassessment of Piasecki's dinocyst assemblages (see "Other Miocene Palynological Studies" section, this chapter).

Manum et al. (in press) also recognized a $L$. truncatum Zone from Norwegian Sea, ODP Leg 104 material (defined by the same criteria as Piasecki's $L$. truncatum Zone) and followed Piasecki in proposing a middle Miocene age for this zone. At Site 643 the L. truncatum Zone of Manum et al. lies unconformably above their $E$. spiridoides Zone (of early Miocene age, based on dinoflagellate evidence, and which contains planktonic foraminifers of Zones N4 through N6 age near its top). Thus, at this site as well, the earliest occurrence of $L$. truncatum is not precisely constrained, although it apparently does not occur lower than planktonic foraminiferal Zone N6 of late early Miocene age.

Elsewhere, $L$. truncatum has been recorded from the middle Miocene of DSDP Site 338, Norwegian Sea (as Cyclonephelium sp. 1, in Manum, 1976); the middle Miocene of the Broeksittard borehole, southeastern Holland (in Zone I, Herngreen, 1987); and from the upper middle through lower upper Miocene (nannofossil Zones NN7 or NN8 through NN9 or NN10, Backman, 1984) from DSDP Hole 555, Rockall Plateau by Edwards (1984b). L truncatum also was recorded from sediments assigned to the middle Miocene (based on foraminifer markers, from Evans and Hughes, 1984) or late Miocene or older (based on dinocyst evidence, in Powell, 1988a) from the British Southwestern Approaches (Powell, 1988a). A form illustrated as L. cf. truncatum in Manum et al. (in press) was recorded from the early Miocene of the Norwegian Sea.

In summary, previous reports suggested a range base of upper lower? or lower middle Miocene for $L$. truncatum, although this datum is not well constrained. We recorded it rarely from Sample 105-645E-75R-4, $15-18 \mathrm{~cm}$ (and questionably in Sample 105-645E-74R, CC) from the early Miocene (below an interval containing nannofossils assigned to Zone NN2/4; Knüttel et al., this volume) of Baffin Bay at Site 645.

\section{Labyrinthodinium sp. cf. L. truncatum}

(Pl. 10, Fig. 2,3)

Remarks. This species differs from $L$. truncatum in having more distally expanded processes, which develop thin, entire (e.g., Pl. 10, Fig. 3 ), or discontinuous platforms. Morphotypes intermediate with L. truncatum were observed.

\section{Genus LOPHOCYSTA Manum, 1979}

Lophocysta sp. cf. L. sulcolimbata Manum, 1979

$$
\text { (Pl. 4, Figs. 10,11) }
$$

Remarks. Specimens here assigned to $L$. sp. cf. $L$. sulcolimbata differ from that taxon by the absence of large pericystal fenestrations (small ones are apparently developed), although are otherwise similar. L. sulcolimbata has been recorded from the lower Miocene of DSDP Site 338, Norwegian Sea (Manum, 1979; and as "Cyclonephelium sp. II" in Manum, 1976) and from the lower Miocene (and a rare occurrence in the early late Miocene) of Site 643, Norwegian Sea (Manum et al., in press).

\section{Lophocysta sp.}

$$
\text { (Pl. 4, Fig. 12) }
$$

Remarks. Central body scabrate and elipsoidal with precingular archeopyle. Periphragm scabrate to faintly granulate in places, ventrally expanded, and attached to central body along an area covering mid-ventral, antapical, and much of the apical region. Low ridges are present on the periphragm and denote obscure paratabulation. Low (about 1.5-2.5 $\mu \mathrm{m}$ high) crests with indented tops, occur on a few ridges in the antapical and mid-ventral areas of the periphragm. Several broadly elliptical perforations about $8 \mu \mathrm{m}$ or less in diameter occur in the pericyst at an approximately equatorial position. A few perforations may occur in apical and antapical areas of the periphragm. A single specimen was found.

This species notably differs from $L$. sulcolimbata in having a periphragm surface that is scabrate or faintly granulate, rather than distinctly striate. Also, openings in the periphragm are less well developed than for $L$. sulcolimbata.
Genus NEMATOSPHAEROPSIS Deflandre and Cookson, 1955 emend. Williams and Downie, 1966

Remarks. A noteworthy feature of many species assigned to this genus is the presence of paired trabeculae, although neither the original nor emended diagnoses of Nematosphaeropsis specify the configuration of trabeculae, and thus as presently emended, no clear distinction exists between Nematosphaeropsis and Cannosphaeropsis (see Head et al., b, this volume)

\section{Nematosphaeropsis downii Brown 1986}

$$
\text { (Pl. 5, Fig. 17) }
$$

Remarks. $N$. downii apparently is restricted to the early Miocene (nannofossil Zones NN3 and NN4) from DSDP Hole 548A, Goban Spur (Brown and Downie, 1985; Brown, 1986), to the early Miocene of ODP Leg 104 in the Norwegian Sea (Manum et al., in press), and to the early Miocene Baffin Bay (this study). A possibly conspecific form, $\mathrm{Ne}$ matosphaeropsis? sp. A of Powell, 1986b from the Langhe Region of northwest Italy occurs within the planktonic foraminiferal Zone N4. Thus, an early Miocene age range is indicated for this taxon, which is in agreement with its occurrence in this study. The body wall of this species was described as "regularly granular" by Brown, 1986. Specimens from this study (as observed using a X100 objective under interference contrast illumination) have a smooth wall surface with regularly distributed, low, rounded "bumps" (slightly less than $1 \mu \mathrm{m}$ diameter) that are separated by a distance roughly equivalent to their diameter. This feature is faintly observed in bright field illumination of the Baffin Bay specimens and seems to be discernible in illustrations of $N$. downii in Brown (1986).

\section{Nematosphaeropsis lemniscata Bujak, 1984}

$$
\text { (Pl. 4, Fig. 3,4) }
$$

Remarks. This species is discussed in Head et al. (a, this volume). Specimens here assigned to $N$. lemniscata show considerable variation in the proportional size of the inner body (see Pl. 4, Figs. 3,4).

\section{Nematosphaeropsis sp. A \\ (Pl. 5, Figs. 18,19)}

Remarks. Cyst with short (6-7 $\mu \mathrm{m})$ process stems and broad (2.0-2.5 $\mu \mathrm{m})$ ribbonlike paired trabeculae. A single ovoidal, or spherical and distorted?, specimen was observed.

\section{Genus OPERCULODINIUM Wall, 1967}

\section{Operculodinium centrocarpum (Deflandre and Cookson, 1955)} Wall, 1967, sensu lato

Remarks. Central body granulate and from 34 to $75 \mu \mathrm{m}$ in diameter, with a wall usually less than $1.0 \mu \mathrm{m}$ thick, occasionally up to $2.5 \mu \mathrm{m}$. Processes thin, finely fibrous, distally aculeate, and from 6 to $17 \mu \mathrm{m}$ long.

\section{Operculodinium israelianum (Rossignol, 1962) Wall, 1967}

Remarks. Central body 59 to $74 \mu \mathrm{m}$ in diameter and processes 3.5 to $7.0 \mu \mathrm{m}$ long in eight specimens recorded. Processes are fibrous and acuminate. Specimens assigned to this taxon have process lengths of about $10 \%$ or less than the central body diameter (10\% or less required for processes on $O$. israelianum, as redefined by Wall, 1967). $O$. israelianum is considered to be a warm-water species, based on its Pleistocene to Holocene stratigraphic and geographic distribution (Harland, 1983; Morzadec-Kerfourn, 1988). However, Harland (1983, p. 331) noted that this species occurs abundantly in lower Pleistocene sediments of the British Isles (Wall and Dale, 1968), at a time when other evidence has suggested that a cold climate prevailed.

Operculodinium vacuolatum $\mathrm{n}$. $\mathrm{sp}$.

$$
\text { (Pl. 9, Figs. 8,9) }
$$

? Operculodinium centrocarpum (Deflandre and Cookson, 1955) Wall, 1967; (in part) Turon and Londeix, 1988, Pl. 4, Figs. 6 through 8 only.

Holotype (Pl. 9, Figs. 8,9). Sample 105-645E-40R-4, 28-33 cm, (5) W5/0; middle or early late? Miocene. 
Derivation of name. From French, vacuole, little vacuum; from Latin, vacuum, an empty space; named with reference to the vacuolate nature of the periphragm and processes.

Diagnosis. Cysts closely appressed biphragmal, proximochorate, spherical to broadly elipsoidal. Endophragm very thin. Periphragm thicker than endophragm and vacuolate, appearing microreticulate, or occasionally microvermiculate in surface view. Periphragm bears low verrucae or bacculae that are vacuolate and have a nontabular distribution. Archeopyle precingular Type P. Operculum free.

Dimensions. Holotype: maximum diameter (excluding processes), $34 \mu \mathrm{m}$, process length, $1.5 \mu \mathrm{m}$. Range in maximum diameter, $33(38.4)$ $50 \mu \mathrm{m}$. Wall is 1.0 to $1.5 \mu \mathrm{m}$ thick. Processes range from 1.0 to $2.5 \mu \mathrm{m}$ long. Fourteen specimens were measured.

Description. The endophragm is thinner than the periphragm and is often barely discernible. The periphragm usually appears microreticulate in plan view, with lacunae of 0.5 to $1.0 \mu \mathrm{m}$ in diameter and muri 0.2 $\mu \mathrm{m}$ wide, although it may appear microvermiculate in some specimens. This pattern is apparently a subsurface feature, reflecting the vacuolate nature of the periphragm, which is just discernible in optical section under bright field microscopy. Processes take the form of verrucae or bacculae and have a diameter of about $2.0 \mu \mathrm{m}$ and are 1.0 to $2.5 \mu \mathrm{m}$ long. These processes are rounded distally, although they may be roundly truncated, and are vacuolate. They have a regular distribution over the entire surface of the cyst and are spaced approximately 1 to $4 \mu \mathrm{m}$ apart. The archeopyle is precingular, apparently Type P3". There is no other expression of paratabulation.

O. vacuolatum $\mathrm{n}$. $\mathrm{sp}$. was recovered from a single sample, where it occurs abundantly. Critical observations of the wall structure could be made only for a small proportion of the cyst population, since in many specimens the cellosize mounting medium used in this study had not penetrated the small cavities occurring within the periphragm and processes.

Remarks. This species is distinguished from other species of Operculodinium by its short processes and the vacuolate nature of its periphragm and processes. An apparently similar specimen was recorded by Turon and Londeix (1988) as "Operculodinium centrocarpum (Deflandre and Cookson, 1955) Wall, 1967; Pl. 4, Figs. 6-8-specimen with reduced processes" from the late Holocene of the western Mediterranean Sea.

\section{Operculodinium sp.}

$$
\text { (Pl. 9, Fig. 5) }
$$

Remarks. Central body broadly elipsoidal or possibly spherical and distorted, with finely granulate wall surface (granules, $0.1-0.3 \mu \mathrm{m}$ ). Wall is $1.2 \mu \mathrm{m}$ thick. Periphragm densely fibrogranulate (appearing almost solid). Endophragm much thinner than periphragm and almost indiscernible. Processes solid, nonfibrous, cylindrical, distally truncated, 3.0 to $4.5 \mu \mathrm{m}$ long, 1.5 to $2.0 \mu \mathrm{m}$ wide, and having a nontabular? distribution with a separation of about $4 \mu \mathrm{m}$. Archeopyle precingular, probably Type P3". Operculum enclosed within cyst and apparently free. A single specimen was observed.

\section{Genus PALAEOCYSTODINIUM Alberti, 196}

Remarks. Published records indicate that the LA of this genus is somewhat diachronous within the North Atlantic and adjacent areas, ranging from early middle Miocene of offshore eastern Canada (Williams and Bujak, 1977b); undifferentiated middle Miocene of the North Sea (Costa, 1980); late middle Miocene of the Bay of Biscay (Harland, 1979), Gulf of Mexico (Duffield and Stein, 1986), and northwest Italy (Powell, 1986b); putative late middle Miocene (Herngreen, 1987) to undifferentiated late Miocene (Herngreen, 1983) of Holland; and early or middle late Miocene of Denmark (Piasecki, 1980), Goban Spur (Brown and Downie, 1985), DSDP Site 555, Rockall Plateau (Edwards, 1984b), and Norwegian Sea (Manum et al., in press). This genus has also been reported from the Beaufort Sea in upper middle to upper Miocene sediments (Dixon et al., 1984) and undifferentiated Miocene sediments (McNiel et al., 1982); has an apparent range top in the early Miocene of DSDP Site 370, offshore northwest Morocco (Williams, 1978); and was recorded from the middle Miocene of the eastern equatorial Pacific (Jarvis and Tocher, 1985).

Palaeocystodinium has a highest occurrence in the lowermost part of nannofossil Zone NN11, both in the Goban Spur (Brown and Downie, 1985 ) and the Rockall Plateau (Edwards, 1984b; correlated from Backman, 1984, p. 421). However, Palaeocystodinium is absent from upper
Miocene sediments (assigned to nannofossil Zones NN10 and NN11) of Site 646B, Labrador Sea (see Head et al.,a, this volume) and from upper Miocene sediments (assigned to nannofossil Zones NN10 and NN9?, Takayama and Sato, 1987) of DSDP Site 611, central North Atlantic (Mudie, 1987). Records thus now indicate Palaeocystodinium to have an LA within the middle of the late Miocene (around 7 to $8 \mathrm{Ma}$ ).

Palaeocystodinium has not been reported from the Miocene of the Northwest Pacific, suggesting a provincial distribution for this species during the Miocene.

\section{Palaeocystodinium golzowense Alberti, 1961}

(PI. 3, Figs. 6,7)

Remarks. Specimens vary somewhat in horn length and endocyst shape. All specimens lack the faint-to-pronounced pericystal reticulation of Svalbardella, some species of which may otherwise appear similar to Palaeocystodinium spp. (e.g., Svalbardella (Palaeocystodinium) spp. of Manum, 1976; Head, pers. obs.).

\section{Palaeocystodinium cf. golzowense of Powell, 1986b}

$$
\text { (Pl. 3, Figs. 8-10) }
$$

Remarks. Specimens differ from those here assigned to $P$. golzowense by their relatively shorter horns. Specimens observed in this study may have faint, low granules on the horns. Specimens morphologically intermediate with $P$. golzowense and $P$. cf. golzowense of Powell, 1986b were recorded in this study, and these two taxa may be ecophenotypic variants of the same species. $P$. cf. golzowense of Powell, 1986b occurs more frequently in the upper part of Zone BB4.

Genus PENTADINIUM Gerlach, 1961 emend. Benedek et al., 1982

Pentadinium laticinctum laticinctum Gerlach, 1961 emend. Benedek et al., 1982

Pentadinium laticinctum is known from the middle Eocene (Costa and Downie, 1979) to the late Miocene (Brown and Downie, 1985; Powell, 1986c and references therein, p. 135; Herngreen, 1987; Manum et al., in press; and Head et al. a, this volume).

Pentadinium laticinctum Gerlach, 1961 emend. Benedek et al., 1982 subsp. A

(Pl. 10, Fig. 11)

Description. Cysts are suturocavate with a vermicular/granulate endophragm and faintly granulate periphragm. Endophragm ornament comprises granules $0.8 \mu \mathrm{m}$ or less, partially coalescent together with sinuous ridges of about 1 to $3 \mu \mathrm{m}$ long and up to $0.8 \mu \mathrm{m}$ wide, resulting in a vermicular pattern in surface view. Paratabulation incompletely expressed by parasutural folds.

Dimensions. Endophragm maximum diameter, 40 to $46 \mu \mathrm{m}$. Periphragm maximum diameter, $65 \mu \mathrm{m}$. Maximum crest height, 10 to 15 $\mu \mathrm{m}$. Periphragm about $0.3 \mu \mathrm{m}$ thick; endophragm, 0.8 to $1.5 \mu \mathrm{m}$ thick. Three specimens were found.

Remarks. This subspecies is distinguished from $P$. laticinctum granulatum Gocht, 1969 in having a vermicular, rather than granulate, endophragm. Possibly similar forms have been recorded as "Pentadinium laticinctum [vermicular]" from the lower to lower upper Oligocene of the Blake Plateau, offshore South Carolina (Stover, 1977) and upper Oligocene of onshore South Carolina (Edwards, 1986).

\section{Pentadinium? sp. A}

(Pl. 10, Figs. 12-16)

Remarks. Suturocavate cysts having an ovoidal to spheroidal outline and a scabrate (endophragmal?) ornament. Paratabulation is more clearly delineated than is typical for Pentadinium (particularly in the sulcal region) and reflects a helicoidal cingulum. Parasutural folds are straight topped, range from 2.0 to $3.5 \mu \mathrm{m}$ high, and may form a slight apical prominence. Overall length is 40 (45.7) $54 \mu \mathrm{m}$, based on 12 specimens. Pentadinium sp. of Ioakim (1979) recorded from the lower Miocene of the North Sea may be similar to Pentadinium? sp. A. but is larger (70 $\mu$ m long).

\section{Pentadinium sp. B}

\section{(Pl. 12, Figs. 1,2)}

Remarks. Suturocavate cysts characterized by a rounded to subrounded ambitus, thick granulate endophragm, and much thinner smooth peri- 
phragm. The periphragm forms low parasutural folds of even height that delineate paratabulation relatively completely, except in the ventral region, where they are absent or reduced. The periphragm is typically closely appressed, or may be slightly wrinkled, in intraplate areas. The archeopyle is large and precingular, probably Type P3". Operculum free. The endocyst lacks indications of paratabulation other than the archeopyle, although a low apical prominence was seen on a few specimens (in Samples 105-645E-62R-1, 138-141 cm, and -33R-4, 92-94 cm). This species is distinguished from others in the genus by its low parasutural folds. Maximum diameter of endocyst is 43 (55.9) $71 \mu \mathrm{m}$. Endophragm is 1.1 to $3.5 \mu \mathrm{m}$ thick. Parasutural folds are from about 1 to 4 $\mu \mathrm{m}$ high. Sixteen specimens were measured.

\section{Genus PYXIDIELLA Cookson and Eisenack, 1958 \\ Pyxidiella/Pyxidinopsis Group}

(Pl. 12, Figs. 15-19)

Remarks. Spherical to broadly ellipsoidal cysts with moderate to thick autophragm. Ornament of low relief consisting of baculae, verrucae, coni, and fine discontinuous reticulation. The archeopyle is clearly intercalary in some, perhaps most, specimens (as for Pyxidiella), but may be precingular in others (as for Pyxidinopsis). Maximum diameter varies from about 33 to $45 \mu \mathrm{m}$. This group occurs rarely (three or less specimens per slide) and so was not subdivided. Some members of this group compare with "cf. Operculodinium sp. of Piasecki, 1980" of Head et al., (a, this volume) from the late Miocene of ODP Site 646 , Labrador Sea (see Head et al., a, this volume, under cf. Operculodinium sp. of Piasecki, for other records that compare with the Pyxidiella/Pyxidinopsis Group).

\section{Genus PYXIDINOPSIS Habib, 1976}

Remarks. Although based on a single species ( $P$. challengerensis) having a low, reticulate ornament, Habib (1976) defined an ornament of variable low relief for Pyxidinopsis and believed that species having granulate and vermicular ornaments would eventually be placed in this genus (Habib, 1976, p. 382).

\section{Pyxidinopsis? sp. 1

$$
\text { (Pl. 12, Fig. 6) }
$$

Remarks. Cysts ellipsoidal, with a thick $(1.2-1.8 \mu \mathrm{m})$ wall, granulate surface bearing low $(0.5 \mu \mathrm{m})$, sparsely scattered coni or verrucae. Maximum length is 36 to $41 \mu \mathrm{m}$. Archeopyle large, approximately trapezoidal and probably precingular (although it might be intercalary, with a much reduced contact between the intercalary paraplate and the precingular paraplates 3" and 5"). Three specimens were identified. This species differs from Pyxidinopsis sp. 2 in having scattered coni and thicker wall, although both forms may possibly be conspecific. Site 645 specimens may fall within the broad definition of Pyxidiella? simplex. Harland (1979) included a variety of ornament types in this taxon, which he recorded from the late Miocene of the Bay of Biscay. P. simplex apparently ranges from the early Miocene (Powell, 1986b) to Pliocene (as ?Pyxidiella sp. nov. in Harland, 1978; as T. simplex in Mudie, 1987) although the broad circumscription and uncertainty of archeopyle type limit the stratigraphic potential of this taxon (see discussion in Lentin and Williams, 1985, p. 301, and Powell, 1986c, p. 135).

\section{Pyxidinopsis sp. 2$$
\text { (Pl. 12, Fig. 5) }
$$

Remarks. Cysts ovoidal to ellipsoidal, with a granulate wall surface and precingular archeopyle; 37 (44.1) $51 \mu \mathrm{m}$ long; wall, 0.6 to $1.4 \mu \mathrm{m}$ thick. Seven specimens were measured. See also comments under " $P y x$ idinopsis? sp. 1" for comparative morphology.

\section{Pyxidinopsis sp. 3}

$$
\text { (PI. 10, Fig. 4) }
$$

Remarks. This species has its first occurrence at the base of Zone BB3. It superficially resembles Habibacysta tectata in having a granulate wall surface, although it lacks tectate elements typifying the latter.

$$
\begin{aligned}
& \text { Pyxidinopsis? sp. } 4 \\
& \text { (P1. 10, Fig. 7) }
\end{aligned}
$$

Remarks. Cysts are approximately spherical and thick-walled (about 0.8 to $1.5 \mu \mathrm{m}$ ), with a fine surface ornament consisting of a combina- tion of punctae and irregular fossulae and foveolae, which are best observed under oil immersion with bright field illumination. Archeopyle precingular. Maximum diameter, 42 (45.7) $50 \mu \mathrm{m}$, based on 10 measurements.

Genus SELENOPEMPHIX Benedek, 1972 emend. Bujak, 1980

Selenopemphix brevispinosa $\mathrm{n}$. sp. (Pl. 7, Figs. 1,2,5)

Synonymy. of text.

? Selenopemphix sp. A Brown and Downie, 1985, Pl. 2, Fig. 20, Fig. 1 in text.

? Selenopemphix sp. B Powell, 1986c, Pl. 1, Fig. 3, Fig. 3 in text. Selenopemphix sp. C Duffield and Stein, 1986; Corradini and Biffi, 1988, Pl. 4, Figs. 1,2.

Holotype (PI. 7, Fig. 5). Sample 105-645E-28R-2, 8-11 cm, (5) U17/ 3 , diameter (excluding processes) is $46 \mu \mathrm{m}$; middle or early late? Miocene.

Derivation of name. Latin, brevis, short, and Latin, spinosus, thorny, prickly; with reference to the short paracingular processes that characterize this species.

Diagnosis. A species of Selenopemphix having smooth to faintly granulate body and parasutural ornament restricted to the paracingular margins and consisting of short distally expanded processes. The archeopyle formed by loss of intercalary paraplate $2 a$ and is large and offset.

Dimensions. Holotype: maximum body diameter (excluding processes), $46 \mu \mathrm{m}$; process, $3.0 \mu \mathrm{m}$ long. Range in maximum body diameter (excluding processes), $36(41.8) 48 \mu \mathrm{m}$; processes from 1.2 to $3.2 \mu \mathrm{m}$ long. Twenty specimens were measured.

Description. Processes are always distally expanded with truncated tips. They are usually slender for most of their length (as on the holotype), although on specimens having short processes, the process stems can be wide ( $1 \mu \mathrm{m}$ or more).

Remarks. This species differs from $S$. coronata Bujak, 1980 in having shorter processes that are less closely spaced and that are always distally separated. Processes on $S$. brevispinosa $\mathrm{n}$. sp. are short and evenly distributed along the paracingular margins, compared with those on $S$. dionaeacysta Head et al. (b, this volume), which are both longer (4-8 $\mu \mathrm{m})$ and may have a loosely clustered distribution along the paracingular margins. This species has been recorded from the Gulf of Mexico, where it may be restricted to mid-Miocene sediments (as Selenopemphix sp. C in Duffield and Stein, 1986); and from the lowermost Pliocene of Italy (as "Selenopemphix sp. C Duffield and Stein, 1986" in Corradini and Biffi, 1988). Selenopemphix sp. A of Brown and Downie, (1985), from the late Miocene of the Goban Spur, and Selenopemphix sp. B of Powell, 1986c (considered by him as synonymous with Selenopemphix sp. A of Brown and Downie, 1985) from the late Miocene of northern Italy may be synonymous with $S$. brevispinosa $\mathrm{n}$. sp., although details of their processes are difficult to determine from the illustrations.

\section{Selenopemphix sp. 1}

(Pl. 7, Figs. 3,7,8)

Remarks. Autocysts, pale brown in color, polar compressed and with a broadly elliptical outline. A pointed apical horn and two roundly pointed antapical horns were observed as folds on a few specimens. The autophragm is thin, has a faintly granulate to faintly granulo/vermiculate surface, and may be crossed by fine wrinkles or folds. The paracingular margins bear low (2.0 to $3.5 \mu \mathrm{m})$, thin crests of constant height. The autophragm is slightly thickened on the paracingular margins just at the base of the crests. The archeopyle is a broad hexa-intercalary. The operculum was in place in most specimens observed. Maximum cyst diameter, including paracingular crests, $40(47.0) 55 \mu \mathrm{m}$. Fifteen specimens were measured.

In addition to the apparently randomly distributed fine wrinkles, several more prominent subradial folds were seen on some specimens, some of which may be parasutural. In particular, a few specimens were observed to have a pair of low $(1.5 \mu \mathrm{m})$ radial folds extending from either side of the parasulcus at the paracingular margin to the top of the apical horn. On one of these specimens, the radial folds bear low (2.0 $\mu \mathrm{m})$, straight-topped crests, similar to those on the paracingular margins. Expression of parasutural features, other than for the paracingulum, however, is obscure for this species. 
S. warriensis Biffi and Grignani, 1983 differs from Selenopemphix sp. 1 in its much larger size (maximum diameter, $85-120 \mu \mathrm{m}$ ) and $S$. nephroides Benedek, 1972 emend. Benedek and Sarjeant, 1981 differs in having a smooth surface and in the absence of paracingular crests.

\section{Selenopemphix? sp. 2}

$$
\text { (Pl. 7, Fig. 4) }
$$

Remarks. A single specimen was found, and it is characterized by short $(1.5 \mu \mathrm{m})$ acuminate paracingular spines and a broadly conical (folded) apical horn, bearing sparsely scattered, short ( $1 \mu \mathrm{m}$ or less) spines. Similar species may have been recorded by Duffield and Stein (1986; as Selenopemphix sp. D, early Miocene, Gulf of Mexico), by Head et al. (a, this volume, as $S$. sp. 2, late Miocene, ODP Site 646 , Labrador Sea) and by Manum, 1976 (as Lejeunecysta paratenella Benedek, middle or late Oligocene, Norwegian Sea).

\section{Selenopemphix sp. 3}

(Pl. 7, Figs. 13,14)

Remarks. Specimens in this study are poorly preserved and may be an allochthonous component. They are characterized by long processes and resemble one of the paratypes of Selenopemphix quanta (Bradford, 1975) Matsuoka, 1985, in Bradford, (1975, Fig. 7 only), reported from recent sediments of the Persian Gulf. This morphotype has longer, more robust processes than the holotype and one other paratype (Figs. 5 and 6 , respectively, in Bradford, 1975). Specimens reported from the Miocene of the Gulf of Mexico (as S. quanta in Duffield and Stein, 1986); upper Oligocene to upper Miocene of northwest Italy (as Multispinula quanta in Powell, 1986a, 1986c); and lowermost Pliocene of Italy (as Multispinula quanta in Corradini and Biffi, 1988), are closer to the more robust morphotype and may be conspecific with the specimens here referred to Selenopemphix sp. 3.

$S$. quanta sensu stricto was not found during this study. Elsewhere, specimens that may be referable to S. quanta s.s. have a range of Miocene (from the Gulf of Mexico, as Selenopemphix armata in Duffield and Stein, 1986), to Pleistocene (e.g., lower Pleistocene of South Carolina, as $S$. quanta in Edwards, 1986), and Holocene (e.g., from the Persian Gulf, as $M$. quanta in Bradford, 1975, Figs. 5 and 6 only; and from Japan, Matsuoka, 1987). S. quanta s.s. occurs in Pleistocene sediments of DSDP Site 611, where it is considered "highly cold-tolerant" by Mudie (1987, Table 3). Matsuoka (1987, p. 62) provided a synonymy for S. quanta (s.s.), and discussed other similar morphotypes from recent sediments.

Genus SPINIFERITES Mantell, 1850 emend. Sarjeant, 1970

Spiniferites pseudofurcatus (Klumpp, 1953) Sarjeant, 1970 emend. Sarjeant, 1981

(Pl. 4, Figs. 7,8)

Remarks. This large, robust species of Spiniferites having distinctive process terminations first appears in the lower Paleogene sequence, along with a number of Miocene records (Corradini, 1978; Costa, 1980; Piasecki, 1980; Bujak and Davies, in Dixon et al., 1984; Brown and Downie, 1985; Jarvis and Tocher, 1985; Bujak and Matsuoka, 1986a; Powell, 1986a, 1986c, 1988a; Matsuoka et al., 1987; El-Beialy, 1988a; Manum et al., in press). S. pseudofurcatus has a useful range top in the middle Miocene of the North Sea (Costa, 1980), while Haq et al. (1987) proposed a range top within the upper Miocene, at the top of the Tortonian (correlated to nannofossil zone, middle NN11; and planktonic foraminiferal zone, lower N17) for this species. Powell (1986c, p. 135) also suggested that the extinction of $S$. pseudofurcatus may be a good stratigraphic marker within the upper Miocene and recorded a last occurrence within Messinian sediments (latest Miocene) in northwestern Italy. However, S. pseudofurcatus has also been recorded from post-Miocene sediments (e.g., as Spiniferites sp., in Habib, 1971; Mudie, 1987; ElBeialy, 1988a; Mudie, in press), and it apparently persisted into the Pleistocene in ODP Site 644, Norwegian Sea (Mudie, in press), DSDP Sites 607 and 611, central North Atlantic (Mudie, 1987), and PliocenePleistocene of offshore West Africa (Williams, 1978). One cannot be sure whether these Pliocene-Pleistocene records represent in-situ occurrences.

\section{Spiniferites sp. 1}

(Pl. 4, Fig. 6)

Remarks. Thin-walled cysts with broadly ovoidal/ellipsoidal endocyst. Processes gonal, with long or short trifurcate (and bifurcate?) terminations that may bear short secondary bifurcations. Periphragm extended antapically, imparting a characteristic elongate outline to cyst. Length of endocyst, $36-39 \mu \mathrm{m}$; total cyst length (including processes), 55-71 $\mu \mathrm{m}$; total length/endocyst length ratio, 1.41 (1.62) 1.82 , based on five measurements.

\section{Spiniferites/Achomosphaera spp.}

Remarks. This multispecific group was not studied in detail and consists of small- to moderate-sized, thin-walled forms having simple bifurcate and trifurcate process terminations.

\section{Genus SUMATRADINIUM Lentin and Williams, 1976}

Remarks. A number of related species appear in figures in the literature and were assigned to Sumatradinium, but were not described and in many cases, details of process morphology are not clear enough from the illustrations to allow one to make detailed comparisons with our material. These include specimens recorded by Williams (1978; as $\mathrm{Su}$ matradinium sp., Pliocene-Pleistocene, offshore northwest Morocco); $\mathrm{Pi}$ asecki (1980; as cf. Polysphaeridium pastielsii, upper Miocene of Denmark); Duffield and Stein (1986; as Sumatradinium sp., lower to upper Miocene, Gulf of Mexico); Corradini and Biffi (1988; as Sumatradinium sp. Duffield and Stein, 1986, lowermost Pliocene of Italy); LeNoir and Hart (1986; as Sumatradinium hispidum, upper lower Miocene, Gulf of Mexico); Wrenn and Kokinos (1986; as Sumatradinium sp., middle or upper Miocene, Gulf of Mexico); Powell (1986b, 1986c; as Sumatradinium? spp. A through D, collectively ranging from upper Oligocene to upper Miocene, northern Italy); and Manum et al. (in press; as Sumatradinium? sp. C and D of Powell, 1986b, lower to lower upper Miocene, Norwegian Sea). A number of new species of Sumatradinium have been reported from the Miocene of offshore eastern Canada; these are believed to have stratigraphically useful range tops (Lentin et al., 1987 and unpubl. data).

Species herein assigned to Sumatradinium are biphragmal, with a large subspherical central body. The endocyst is brown and almost opaque due to pigmentation, and most specimens have a fairly smooth surface. The pericyst is much thinner than the endocyst and is closely appressed, except where it forms processes. Specimens are poorly preserved, often with crushed processes, and are probably allochthonous.

Species of Sumatradinium in this study were provisionally recog. nized according to process morphology, as follows:

\section{Sumatradinium $\mathrm{sp}$. A}

(Pl. 8, Figs. 2,3)

This species is distinguished by branched process tips.

\section{Sumatradinium sp. B}

$$
\text { (Pl. 8, Fig. 7) }
$$

This species is distinguished by tapering, unbranched processes.

$$
\text { Sumatradinium sp. of Duffield and Stein, } 1986
$$

$$
\text { (Pl. 8, Fig. 5) }
$$

Remarks. Specimens here assigned to Sumatradinium sp. of Duffield and Stein, 1986, (Pl.3, Fig.2 only) have unbranched, distally rounded processes. This species has been recorded from the lower to upper Miocene, Gulf of Mexico (as Sumatradinium sp., in Duffield and Stein, 1986); and the lowermost Pliocene of Italy (as Sumatradinium sp. Duffield and Stein, 1986, in Corradini and Biffi, 1988).

\section{Genus SYSTEMATOPHORA Klement, 1960}

\section{Systematophora ancyrea Cookson and Eisenack, 1965}

$$
\text { (Pl. 5, Fig. 14) }
$$

Remarks. Bujak and Matsuoka (1986b) considered this species different from $S$. placacantha in having less complete penitabular process complexes, and processes that are longer and thinner. However, they observed intermediate specimens, and records of these two species are not 
always reliably separated in the literature. $S$. ancyrea (elsewhere recorded also as $S$. placacantha) apparently has an diachronous LA that ranges from up to middle Miocene (Harland, 1978; Manum, 1976; Williams, 1978; Piasecki, 1980; Edwards,1984b; Bujak and Matsuoka, 1986a; Matsuoka et al., 1987; Herngreen, 1987; Mudie, in press) to late Miocene (Partridge, 1978; Powell, 1986c, extending partly up into planktonic foraminiferal Zone N17; Manum et al., in press; and as "Areoligera senonensis complex" from the Goban Spur in Brown and Downie, 1985 last appearing in planktonic foraminiferal zone, lower N16). Systematophora spp. are notably absent from the entire late Miocene of DSDP Site 611, central North Atlantic (Mudie, 1987) and from the late Miocene (nannofossil Zones NN10 and above) of ODP Site 646B, Labrador Sea (Head et al., a, this volume). Available records indicate that within the North Atlantic, this species does not extend higher than the early late Miocene.

\section{Genus TECTATODINIUM Wall, 1967}

cf. Tectatodinium sp. 1 of Manum, 1976 (Pl. 12, Fig. 9)

Remarks. This small species, having thick fibrous periphragm and thin fibrous/filamentous processes, is similar to a species recorded from the Oligocene to middle Miocene of ODP Site 338, Norwegian Sea (Manum, 1976) and from the Eocene of Site 642, Norwegian Sea, (Manum et al., in press). The archeopyle style could not be determined for specimens in this study. These also appeared rather flattened, which prevented us from making a confident identification.

\section{Genus THALASSIPHORA Eisenack and Gocht, 1960 emend. Benedek and Gocht, 1981 \\ Thalassiphora? sp. 1 \\ (Pl. 6, Figs. 7-10)}

Remarks. Specimens have spherical endocyst and thin folded periphragm. Details of the morphology could not be discerned. A solid tapering spur was observed attached to the periphragm of one specimen (Pl. 6, Figs. 8,9), although this feature was not seen with certainty on any other specimens.

\section{Genus TRINOVANTEDINIUM Reid, 1977 emend. Bujak, 1984}

\section{Trinovantedinium sp. A}

(Pl. 8, Figs. 4, 8-10)

Remarks. Cysts having a pentagonal outline and variably expressed antapical horns, which may be pointed and well developed, or reduced to rounded lobes. The autophragm is smooth to faintly granulate and brown in color. A paracingulum, delineated by low folds, occurs on some specimens. Processes are short (4 to $8 \mu \mathrm{m})$ and solid (although may have hollow bases), distally expanded, and are evenly distributed over the cyst surface, although may show some alignment, including along the paracingular folds, when present. The archeopyle style was not determined. Main body length, excluding processes, is 41 (53.8) 74 $\mu \mathrm{m}$. Fourteen specimens were measured.

\section{DINOFLAGELLATE CYSTS OF UNKNOWN GENERIC AFFINITY \\ Gen. et sp. indet. of Piasecki, 1980 \\ (Pl. 12, Figs. 10-14)}

Remarks. Specimens assigned to the "Gen. et sp. indet. of Piasecki, 1980 " group have a precingular archeopyle, scabrate to finely granulate wall, and variable process morphology ranging from well-developed arcuate ridges to narrow, truncated bladelike processes. This compares with the morphologic range illustrated by Manum et al. (in press) for this taxon group. Gen. et sp. indet. of Piasecki has been reported from the early middle Miocene of the North Atlantic (Edwards, 1984b), from the early middle to early late Miocene of Denmark (Piasecki, 1980), and the middle and early late Miocene of ODP Site 643, Norwegian Sea (Manum, in press). Its first occurrence in the present study (in Sample $105-645 \mathrm{E}-75 \mathrm{R}-4,15-18 \mathrm{~cm}$ ) extends the range of this taxon into the early Miocene.

\author{
INCERTAE SEDIS \\ Group ACRITARCHA Evitt, 1963 \\ Acritarch sp. 1 \\ (P1. 5, Figs. 3,4, and 7-10)
}

Remarks. Specimens have a cancellous equatorial collar, attached by five fibrous or fibro-cancellous radial struts, to a centrally located inner body. This inner body has a thin (about $0.3 \mu \mathrm{m}$ ), smooth, hyaline wall that is crumpled on observed specimens, but probably elipsoidal and coaxial with the equatorial collar. The collar has a circular to broadly elliptical outline, to the outer side of which a thin smooth membrane is closely appressed. This membrane extends toward the inner body, without apparently joining it, and forms a narrow (about 2-3 $\mu \mathrm{m}$ ), inwardly directed flange on either side of the equatorial collar. Several small rods (probably analogous with the fibrous elements in Acritarch sp. 2) may be associated with the central body. These rods are fibrous to fibro-cancellous, up to about $3.5 \mu \mathrm{m}$ long and are flared at both ends. The maximum diameter of the equatorial collar ranges from $23(26.7)$ to $30 \mu \mathrm{m}$ and has a minimum thickness of $1.7 \mu \mathrm{m}$. The inner body has a diameter of $8(10.4) 13 \mu \mathrm{m}$ based on 10 measurements. All specimens found were polar compressed.

Acritarch sp. 1 was recorded only from dinocyst Zone BB1. However, a specimen transitional between Acritarch sp. 1 and 2 was observed in Sample 105-645E-63R-6, 16-19 cm, within dinocyst Zone BB3. Specimens probably conspecific with this species were recorded from the middle Eocene through lower Oligocene (nannofossil Zones NP16 through NP21) of Hole 647A in the Labrador Sea (as "cf. Acritarch sp. 1 of Head et al., c, this volume," in Head and Norris, this volume).

\section{Acritarch sp. 2 \\ (Pl. 5, Figs. 1,2)}

Remarks. Specimens have a wide cancellous equatorial collar with a circular to broadly elliptical and entire outline, encircling a thin (up to $0.6 \mu \mathrm{m}$ ) walled inner body that is crumpled on observed specimens. Several short (up to $6 \mu \mathrm{m}$ long) fibrous to fibro-cancellous rods, flared at both ends, and lying across or within? the inner body were seen on a number of specimens. The equatorial collar has a maximum diameter of $23(30.5) 38 \mu \mathrm{m}$ and is 7 to $11 \mu \mathrm{m}$ wide; the inner body has a maximum diameter of 10 to $15 \mu \mathrm{m}$; based on 11 specimens.

Some specimens observed with two or three radial fenestrations within the equatorial collar may represent intermediate forms with Acritarch sp. 1.

Genus CYCLOPSIELLA Drugg and Loeblich, 1967 n. emend.

Original diagnosis (Drugg and Loeblich, 1967, p. 188). Cyst that is small, flattened, and ellipsoidal in outline. A small circular aperture is present on one face just below the apex. The aperture is closed by a circular plug.

Previous emended diagnosis. Cyst spherical to subspherical, small, flattened; aperture circular, apical, closed by a circular plug (Jain and Dutta, in Dutta and Jain, 1980, p. 71).

Emended diagnosis. Organic-walled microfossils, oblate and circular to elliptical in outline. Wall is biphragmal, with a thin membranous periphragm that is loosely or closely appressed to the endophragm and that may form an ambital flange. Endophragm smooth or may bear low ornament. Periphragm smooth or wrinkled and may bear ornament on the apertural side, and absent or reduced ornament on the antapertural side. An approximately circular pylome is located subapically within the endophragm and may have a thickened or raised rim. An apertural plug may be present. An equatorial line of thickening or folding may occur across the main body.

Type species. Cyclopsiella elliptica Drugg and Loeblich, 1967 p. 190, Pl. 3, Figs. 1 through 6; Fig. 7 in text.

Discussion. Drugg and Loeblich (1967) proposed two new acritarch genera, Cyclopsiella and Ascostomocystis, from the Oligocene and Eocene, respectively, of the Gulf Coast. Cyclopsiella was given a broad circumscription, which did not define wall relationships, although a biphragmal wall having a thin, filmy periphragm occurs in Cyclopsiella elliptica, the type species. However, Drugg and Loeblich (1967) clearly specified a subapical position for the pylome in Cyclopsiella. Jain and Dutta (in Dutta and Jain, 1980, p. 71) emended Cyclopsiella to encompass spherical to ellipsoidal specimens having an apical aperture. Those spec- 
imens (including by inference, the type specimens of $C$. elliptica) that have a subapically oriented pylome, were considered to have undergone compression subnormal to their long axis. We reject this contention on the basis that the pylome on the type specimens of $A$. elliptica (as illustrated by Drugg and Loeblich, 1967) is clearly subapical as an original feature. This is shown by its position relative not only to the ambitus (and ambital flange on some species) but also to the equatorial thickening of specimens of $C$. elliptica as illustrated by Drugg and Loeblich (1967). Cyclopsiella most significantly differs from Ascostomocystis in having an apically located pylome. Fromea Cookson and Eisenack emend. Yun, 1981; Palaeostomocystis Deflandre, 1937b emend. Deflandre, 1966; and Beringiella Bujak, 1984 also differ from Cyclopsiella in having an apically located pylome and autophragm. Halodinium Bujak, 1984 differs from Cyclopsiella in having a circular pylome located at the centre of the main body. Collumosphaera Jain and Dutta in Dutta and Jain (1980) differs from Cyclopsiella, as emended here, in having a spherical or subspherical body and apical pylome.

Accepted species. Cyclopsiella coniata Jain and Tandon, 1981, p. 14,

Pl. 2, Figs. 32,33.

Cyclopsiella deltoides $\mathrm{He}$ and $\mathrm{Li}, 1981$, p. 70, Pl. 35, Fig. 1.

Cyclopsiella elliptica, Drugg and Loeblich, 1967, p. 190, Pl. 3, Figs. 1-6. text-fig. 7.

Cyclopsiella granulata $\mathrm{He}$ and Li, 1981, p. 69, Pl. 35, Figs. 4-8.

Cyclopsiella ornamenta Jain, 1977, p. 187, Pl. 6, Fig. 72.

Cyclopsiella rhomboidalis $\mathrm{He}$ and $\mathrm{Li}, 1981$, p. 70, Pl. 35, Fig. 2; Fig. 7 in text.

Cyclopsiella vieta Drugg and Loeblich, 1967, p. 192, 194, Pl. 3, Figs. 7-9, text-Fig. 8.

Reattributed species. Ascostomocystis granosa Matsuoka, 1983, p. 141, Pl. 8, Figs. 5,7, and 8 is transferred herein to: Cyclopsiella granosa (Matsuoka, 1983) n. comb. and is considered to be a junior synonym of

Cyclopsiella granulata $\mathrm{He}$ and $\mathrm{Li}, 1981$.

Synonymy for $C$. granulata $\mathrm{He}$ and $\mathrm{Li}, 1981$ :

Ascostomocystis sp. I Manum, 1976, Pl. 6, Figs. 1,2,5.

Cyclopsiella granulata $\mathrm{He}$ and $\mathrm{Li}, 1981$, p. 69, Pl. 35, Figs. 4-8.

Ascostomocystis granosa Matsuoka, 1983, p. 141, Pl. 8, Figs. 5,7,8.

Ascostomocystis sp. I Manum, 1976; Williams and Bujak, 1985,

Fig. 22,13; Fig. 19 in text.

Ascostomocystis granosa Matsuoka, 1983; Bujak and Matsuoka, 1986a, Fig. 2 in text.

Ascostomocystis sp. I in Manum, 1976; Herngreen, 1987, p. 37.

Ascostomocystis granosa Matsuoka, 1983; Manum et al., in press.

Cyclopsiella granosa (Matsuoka, 1983) n. comb.

Taxonomic note on Cyclopsiella granulata $\mathrm{He}$ and $\mathrm{Li}$ :

A. granosa Matsuoka, 1983, described from the early to early middle Miocene of Japan (Matsuoka, 1983; Bujak and Matsuoka, 1986a), has a subapical pylome and thus is transferred herein to Cyclopsiella $\mathrm{n}$. emend. Furthermore, C. granosa (Matsuoka, 1983) n. comb. is considered by us to be a junior synonym of Cyclopsiella granulata $\mathrm{He}$ and $\mathrm{Li}$ 1981 , from the late Oligocene of offshore China, based upon similarities between their respective descriptions. Both species were synonymized by their respective authors, with Ascostomocystis sp. 1 of Manum, 1976, which was recorded from the early and middle Miocene of the Norwegian Sea.

Since $C$. granosa (Matsuoka) n. comb. is the nominate species of the Ascostomocystis granosa Zone of Manum et al. (in press), this zone should now be cited as the Cyclopsiella granulata $\mathrm{He}$ and Li Zone of Manum et al.

Provisionally accepted species. Cyclopsiella(?) trematophora (Cookson and Eisenack, 1967) Lentin and Williams, 1977. This species was originally placed by Cookson and Eisenack (1967a) in Leiosphaeridia. It is uncertain whether this species has a single wall layer, or two wall layers, as required for Cyclopsiella n. emend.

Cyclopsiella(?) mura Duxbury, 1983, p. 67, PI. 9, Fig. 15. The provisional allocation of this species also results from uncertainty of the presence of two wall layers.

Provisionally reattributed species. Ascostomocystis laevigatus Chateauneuf, 1980, p. 133, Pl. 19, Figs. 6,9 is here transferred to:

\section{Cyclopsiella? laevigata (Chateauneuf) n. comb.}

The provisional transfer of this species is based on the apparent subapical location of the pylome.

Ascostomocystis granulatus Chateauneuf, 1980, p. 133, Pl. 19, Figs. 8,11 is here provisionally transferred to Cyclopsiella and renamed Cyclo- psiella? chateauneufii nom. nov.(pro. Ascostomocystis granulatus Chateauneuf, 1980)

Holotype. Chateauneuf, 1980, Pl. 19, Fig. 8; late middle Eocene.

Derivation of name. Named in honor of the palynologist, JeanJacques Chateauneuf.

Remarks. The provisional transfer of this species is based on the apparent subapical location of the pylome. As the name granulatus is already occupied by Cyclopsiella granulata $\mathrm{He}$ and $\mathrm{Li}, 1981, A$. granulatus Chateauneuf is here renamed, in accordance with Article 55.1 of the I.C.B.N.

\section{Cyclopsiella spiculosa $\mathrm{n}$. sp.}

(PI. 5, Figs. 20,21)

Holotype (Pl. 5, Fig. 21). Sample 105-645E-69R, CC (5) N11/0; lower or middle Miocene.

Derivation of name. Latin, spiculum, a little sharp point; and Latin, - osus, full of, possesses in abundance; with reference to the spinulose ornament present on the endocyst.

Diagnosis. Main body is elliptical in outline. Endophragm hyaline and thin, becoming thicker (up to about $1.0 \mu \mathrm{m}$ ) toward the endocyst ambitus, and has a smooth surface. The periphragm is membranous and much thinner than the endophragm. It is closely appressed to the endophragm except at the endocyst ambitus, where it forms a thin, membranous, finely wrinkled, flange with an entire or ragged outer margin. This flange entirely surrounds the ambitus. The periphragm bears regularly distributed spinules that occur on the apertural side of the cyst only. A circular to elipsoidal pylome is subapically located and is coincident in both endophragm and periphragm. This pylome has a smooth or slightly irregular rim, which may be slightly thickened. An apertural plug was not observed.

Dimensions. Holotype: Endocyst length, $55 \mu \mathrm{m}$; endocyst width, 51 $\mu \mathrm{m}$; maximum width of equatorial flange, $6 \mu \mathrm{m}$; spinule length, $2.0 \mu \mathrm{m}$, width, $0.9 \mu \mathrm{m}$, separation between adjacent spinules, about $2.0 \mu \mathrm{m}$; pylome maximum diameter, $8 \mu \mathrm{m}$.

Range: Endocyst length, 50 (58.7) $69 \mu \mathrm{m}$; maximum width of ambital flange, 3.5 (5.5) $9 \mu \mathrm{m}$; endocyst length/width ratio, 1.07 (1.21) 1.29. Fifteen specimens were measured.

Description. The periphragm is extremely thin and is closely appressed to the endophragm where it overlies the endocyst. Adjacent spinules have a separation of 1.5 to $2.7 \mu \mathrm{m}$ at their base. Spinules are about 1.4 to $2.3 \mu \mathrm{m}$ long (but $3.4 \mu \mathrm{m}$ in one specimen from Sample 105-645E-69R, CC) and about 0.5 to $0.9 \mu \mathrm{m}$ in basal diameter, straight or slightly curved, and taper to sharp or blunt tips. A pylome was observed in six specimens. This pylome is circular to elliptical, with a diameter of 7 to $9 \mu \mathrm{m}$, and is located within the endophragm and periphragm, just below the apex at one end of the endocyst. It has a smooth or slightly irregular rim, which may be slightly thickened to produce a collar up to $2 \mu \mathrm{m}$ wide.

Comments. Specimens have a fairly constant orientation, indicating primary compression normal to the plane of the ambital flange. In one specimen, the pylome was located apically, on the margin of the endocyst, although displacement of the ambital flange in the apical region indicated that this specimen was distorted during preservation. The precise three-dimensional shape of Cyclopsiella spiculosa $\mathrm{n}$. sp could not be determined with certainty. Spinules are distributed on only one side of the cyst; the other side was not clearly discernible and is presumably thin and smooth. Equatorial features (e.g., thickening in C. elliptica and folds in $C$. vieta) were not seen on specimens of $C$. spiculosa $\mathrm{n}$. sp.

Remarks. Cyclopsiella spiculosa n. sp. is larger than Cyclopsiella elliptica Drugg and Loeblich (30-60 $\mu \mathrm{m}$ long), described from the Oligocene of Mississippi, and lacks a thickened central band, which is common in C. elliptica. Processes on C. elliptica are more hairlike and range from extremely short up to $7 \mu \mathrm{m}$ long. The periphragmal flange consistently present in $C$. spiculosa $\mathrm{n}$. sp. occurs only rarely in C. elliptica.

C. spiculosa n. sp. resembles Cyclopsiella granulata $\mathrm{He}$ and $\mathrm{Li}$, 1981, (= Cyclopsiella granosa [Matsuoka] n. comb.) recorded from the late Oligocene of China ( $\mathrm{He}$ and $\mathrm{Li}, 1981)$ and the upper lower to lower middle Miocene of Japan (as Ascostomocystis granosa in Matsuoka, 1983; Bujak and Matsuoka, 1986a), but has spinules rather than the coarse granules that characterize $C$. granulata. $C$. granulata has also been reported from the early Miocene to early late Miocene of the Norwegian Sea (as Ascostomocystis sp. 1 in Manum, 1976; and as Ascostomocystis granosa in Manum et al., in press), and from the putative late Miocene (Tortonian) of southeastern Holland (as A. sp. 1 of Manum, 
1976, in Herngreen, 1987). Specimens attributed by Piasecki (1980, p. 74, Pl. 2, Fig. 7; Pl. 5, Figs. 3, 4) to C. elliptica, from the middle Miocene of Denmark, have an ornament similar to that of $C$. spiculosa $\mathrm{n}$. sp. However, Piasecki's specimens are smaller (about 25 to $35 \mu \mathrm{m}$, measured from the illustrations) and lack an ambital flange.

Cyclopsiella coniata Jain and Tandon, 1981, from the middle Eocene of India, resembles Cyclopsiella spiculosa n. sp., although it has coni, rather than spinules, and may also be larger (central body diameter, 74-76 $\mu \mathrm{m}$, measured from illustrations of two specimens) than $C y$ clopsiella spiculosa $\mathrm{n}$. sp.

\section{Cyclopsiella? sp. cf. C.? trematophora (Cookson and Eisenack, 1967) Lentin and Williams, 1977} (Pl. 4, Fig. 5)

Remarks. Specimens have an oval outline and appear to represent detached and slightly concave halves. The wall is thin, hyaline, and wrinkled, with a smooth surface and slightly thickened margin. A circular subapical opening (pylome?) of 7 to $8 \mu \mathrm{m}$ in diameter having a somewhat irregular, unthickened rim was observed in a few specimens. Length is 71 to $81 \mu \mathrm{m}$. Eight specimens were found. Identification of the Baffin Bay specimens is provisional owing to their wrinkled appearance, which is not typical for C.? trematophora.

C.? trematophora has a known range of Paleocene through Eocene (Wrenn and Hart, 1988 and references therein).

\section{Genus CYMATIOSPHAERA Wetzel, 1933 emend. Deflandre, 1954 \\ Cymatiosphaera? baffinensis n. sp. \\ (Pl. 5, Figs. 5,6,11,12,16)}

Holotype (Pl. 5, Figs. 6,12,16). Sample 105-645E-50R, CC (4) S25/ 2; middle or early late Miocene.

Derivation of name. Named with reference to Baffin Bay, where ODP Site 645 is the type locality for this species.

Diagnosis. A small acritarch species with an obscure, thin, spherical, smooth central body, bearing prominent crests that subdivide the surface into about 12 to 14 irregularly polygonal fields. Crests are developed as folds of closely appressed wall layer and are about 0.7 to $1.1 \mu \mathrm{m}$ thick. Crests are of even height, but a subtriangular depression occurs at the interconnecting point of crest tops because of an invagination of the crest.

Dimensions. Holotype: Overall dimensions, $34 \times 28 \mu \mathrm{m}$; crest height, $6 \mu \mathrm{m}$; crest thickness, $1.0 \mu \mathrm{m}$. Range in overall maximum diameter, 24 (28.2) $34 \mu \mathrm{m}$; crest height, 6 to $8 \mu \mathrm{m}$; crest thickness, 0.7 to $1.1 \mu \mathrm{m}$. Ten specimens were measured.

Description. Specimens are small and hyaline, with a central body that is thin and frequently obscured by the thicker crests. We were unable to determine if an aperture was present on the central body. Crests appear sinuous, resulting in the delineation of irregularly polygonal fields. Crest junctions are characteristically Y-shaped in optical cross section because of invagination of the crest top at the point of intersection. These gonal depressions have rounded bases and are up to $2 \mu \mathrm{m}$ deep.

Discussion. $C$.? baffinensis $\mathrm{n}$. $\mathrm{sp}$. is similar to C.? invaginata Head et al. (b, this volume) but has thicker crests $(0.2-0.5 \mu \mathrm{m}$ for $C$.? invaginata), which appear to form fewer polygonal fields (about 20 for $C$.? invaginata), and has greater overall dimensions.

The generic placement of this species is provisional, since no species of Cymatiosphaera known to us has crests produced from appressed folds.

\section{Cymatiosphaera? invaginata Head et al., a, this volume}

Remarks. This acritarch species is abundant at Site 646, from the late Miocene of the Labrador Sea (Head et al., a, b, this volume). It has also been recorded from the late Miocene and early Pliocene of DSDP Leg 94 Sites 607 (central North Atlantic) and 611 (northern North Atlantic), being recorded frequently at Site 611 , and from the late Miocene to late Pliocene (common in Zone PM3) of the Norwegian Sea (as ?Cymatiosphaera sp. 1 in Mudie, in press). This species was recorded only rarely from Zone BB5 at Site 645. See also under Cymatiosphaera? sp. for comparative morphology.

\section{Cymatiosphaera? sp.}

(Pl. 5, Fig. 15)

Remarks. This species has similar crests to Cymatiosphaera? baffinensis $\mathrm{n}$. sp., but differs in having a thick-walled and prominent spherical central body. The overall diameter ranges from 26 to $38 \mu \mathrm{m}$, with a crest height of 4 to $8 \mu \mathrm{m}$ and a central body wall 0.6 to $1.3 \mu \mathrm{m}$ thick. No apertures were seen in the central body.

Genus LEIOSPHAERIDIA Eisenack, 1958, emend. Downie and Sarjeant, 1963.

\section{Leiosphaeridia $\mathrm{sp}$.}

(Pl. 9, Fig. 10)

Remarks. Main body is ovoidal/ellipsoidal to spherical, with unstructured hyaline wall from 0.8 to $2.0 \mu$ m thick, a smooth surface, and short slitlike pylome that usually occurs near the margin on compressed specimens (e.g., see near-bottom margin of illustrated specimen). Maximum diameter is $23(27.4) 31 \mu \mathrm{m}$, based on 13 specimens.

A few (1-3) scattered small hyaline bodies (granules, verrucae, or irregular coni) up to $1.5 \mu \mathrm{m}$ high were observed on the surfaces of some specimens, although these may be preservational artifacts.

Forms similar to this species have a long stratigraphic range. The abundance of this species in Zone BB5 and its restricted range suggest an environmental control for its distribution at Site 645 .

\section{ACKNOWLEDGMENTS}

Financial support for this project was obtained from a Natural Sciences and Engineering Research Council of Canada operating grant to G. Norris; from the Dept. of Energy Mines and Resources Research Agreement Nos. 66, 96, and 195 to G. Norris and M. J. Head; and from Geological Survey of Canada support for Project 820044 of P. J. Mudie. We thank J. Dabros and K. MacNeil (Atlantic Geoscience Centre) for preparation of samples used by P.J.M. and K. Hanson and P. B. O'Donovan (Univ. of Toronto) for photographic assistance. We thank G. L. Williams and R. Fensome for their hospitality during a visit by M. J. Head to the Bedford Oceanographic Institute, Nova Scotia in 1986, S. B. Manum for making available to us a pre-publication copy of ODP Leg 104 palynological results, and A. de Vernal (Univ. Québec à Montréal) and J. H. Wrenn (Amoco Prod. Co., Tulsa) for several opportunities to discuss and compare palynomorph taxa from ODP Legs 104 and 105 and from the southeastern U.S., respectively. Shen Yun and Gang Chai (Univ. of Toronto) kindly translated Chinese dinocyst descriptions. The manuscript was reviewed by John $\mathrm{H}$. Wrenn, whose careful and perceptive critical comments greatly improved this chapter.

\section{REFERENCES}

Taxonomic references prior to 1985 are not comprehensively listed below, and the reader is referred to Lentin and Williams (1985) for these.

Aksu, A. E., and Mudie, P. J., 1985. Magnetostratigraphy and palynology demonstrate at least 4 million years of Arctic Ocean sedimentation. Nature, 318:280-283.

Andrews, G. W., 1988. A revised marine diatom zonation for Miocene strata of the southeastern United States. U.S. Geol. Surv. Prof. Pap, 1481:1-29.

Aubry, M.-P., 1985. Northwestern European Paleogene magnetostratigraphy, biostratigraphy, and paleogeography: Calcareous nannofossil evidence. Geology, 13:198-202.

Aubry, M. P., Hailwood, E. A., and Townsend, H. A., 1986. Magnetic and calcareous-nannofossil stratigraphy of the lower Paleogene formations of the Hampshire and London basins. J. Geol. Soc. (London), 143:729-735.

Auffret, J. P., and Graus-Cavagnetto, C., 1975. Les formations Paléogènes sous-marines de la Manche Orientale Données palynologiques. Bull. Soc. Geol. France, Ser. 7, 17(5):641-655.

Backman, J., 1984. Cenozoic calcareous nannofossil biostratigraphy from the northeastern Atlantic Ocean-Deep Sea Drilling Project Leg 81. In Roberts, D.G., Schnitker, D., et al., Init. Repts. DSDP, 81: Washington (U.S. Govt. Printing Office), 403-428.

Baldauf, J. G., 1984. Cenozoic diatom biostratigraphy and paleoceanography of the Rockall Plateau region, North Atlantic, Deep Sea Drilling Project Leg 81. In Roberts, D. G., Schnitker, D., et al., Init. 
Repts. DSDP, 81: Washington (U.S. Govt. Printing Office), 439478.

Ballog, R. A., and Malloy, R. E., 1981. Neogene palynology from the southern California continental borderland, Site 467, Deep Sea Drilling Project 63. In Yeats, R. S., Haq, B. U., et al., Init. Repts. DSDP, 63: Washington (U.S. Govt. Printing Office), 565-576.

Baltes, N., 1967. Microflora from Miocene salt-bearing formation of the pre-Carpathian depression (Roumania). Rev. Palaeobot. Palynol., 2:183-194.

1969. Distribution stratigraphique des dinoflagellés et des acritarches tertiaires en Roumanie. In Brönniman, P., and Renz, H. H. (Eds.), Proc. First Int. Conf. Planktonic Microfossils (Geneva, 1967): Leiden (E. J. Brill), 1:26-45.

Barss, M. S., Bujak, J. P., and Williams, G. L., 1979. Palynological zonation and correlation of 67 wells, eastern Canada. Geol. Surv. Canada Pap., 78-24:1-117.

Benedek, P. N., 1972. Phytoplanktonten aus dem Mittel- und Oberoligozän von Tönisberg (Niederrheingebiet). Palaeontographica, Abt. B, 137:1-71.

1980. Vorläufige Ergebnisse der Phytoplankton-Untersuchungen aus dem nordwesteuropäischen Tertiärbecken. In Vinken, R., and Meyer, K.-J. (Eds.), Project 124: The Northwest European Tertiary Basin. IGCP Rept. 6:87-92.

Benedek, P. N., and Müller, C., 1976. Die Grenze Unter/Mittel-Oligozän am Doberg bei Bünde/Westfalen. I. Phyto-und Nannoplankton. Neu. Jahrb. Geol. Paläont. Monatsh., 1976, 3:129-144.

Benedek, P. N., and Sarjeant, W.A.S., 1981. Dinoflagellate cysts from the middle and upper Oligocene of Tönisberg (Niederrheingebiet): a morphological and taxonomic restudy. Nova Hedwigia, 35:313-356.

Berggren, W. A., and Schnitker, D., 1983. Cenozoic marine environments in the North Atlantic and Norwegian-Greenland Sea. In Bott, M.H.P. et al. (Eds.), Structure and Development of the GreenlandScotland Ridge; New Methods and Concepts, NATO Conf. Ser. IV, Vol. 8: New York (Plenum Press), 495-548.

Berggren, W. A., Kent, D. V., and Van Couvering, J. A., 1985. Neogene geochronology and chronostratigraphy. In Snelling, N. J. (Ed.), The Chronology of the Geological Record. Geol. Soc. (London) Mem., 10:211-260.

Brosius, M., 1963. Plankton aus dem nordhessischen Kasseler Meeressand (Oberoligozän). Z. dt. Geol. Ges., 114(1):32-56.

Bradford, M. R., 1975. New dinoflagellate cyst genera from the recent sediments of the Persian Gulf. Can. J. Bot., 53:3064-3074.

Brown, S., 1986. Nematosphaeropsis downii sp. nov.: a new dinoflagellate cyst from Miocene sediments in the Bay of Biscay. J. Micropalaeontol., 5(1):7-10.

Brown, S., and Downie, C., 1984. Dinoflagellate cyst biostratigraphy of late Paleocene and early Eocene sediments from Sites 552, 553, and 555, Leg 81, Deep Sea Drilling Project (Rockall Plateau). In Roberts, D. G., Schnitker, D., et al., Init. Repts. DSDP, 81: Washington (U.S. Govt. Printing Office), 565-579.

1985. Dinoflagellate cyst stratigraphy of Paleocene to Miocene sediments from the Goban Spur (Sites 548-550, Leg 80). In Graciansky, P. C. de, Poag, C. W., et al., Init. Repts. DSDP, 81: Washington (U.S. Govt. Printing Office), 643-651.

Bujak, J. P., 1980. Dinoflagellate cysts and acritarchs from the Eocene Barton Beds of southern England. In Bujak, J. P., Downie, C., Eaton, G. L., and Williams, G. L. (Eds.), Dinoflagellate Cysts and Acritarchs from the Eocene of Southern England. Palaeontol. Assoc. Spec. Pap. Palaeontol., 24:36-96.

1984. Cenozoic dinoflagellate cysts and acritarchs from the Bering Sea and northern North Pacific, DSDP, Leg 19. Micropalaeontology, 30(2):180-212.

Bujak, J. P., Downie, C., Eaton, G. L., and Williams, G. L., 1980. Dinoflagellate cysts and acritarchs from the Eocene of southern England. Palaeontol. Assoc. Spec. Pap. Palaeontol., 24:26-36.

Bujak, J. P., and Davies, E. H., 1981. Neogene dinoflagellate cysts from the Hunt Dome Kopanoar M-13 well, Beaufort Sea, Canada. Bull. Can. Pet. Geol., 29(3):420-425.

Bujak, J. P., and Matsuoka, K., 1986a. Late Cenozoic dinoflagellate cyst zonation in the western and northern Pacific. In Wrenn, J., et al., First Symp. Neogene Dinoflagellate Cyst Biostratigraphy. AASP Contr. Ser., 17:7-25.

1986b. Taxonomic reallocation of Cenozoic dinoflagellate cysts from Japan and the Bering Sea. Palynology, 10:235-242.
Chateauneuf, J.-J., 1980. Palynostratigraphie et Paléoclimatologie de 1 'Eocène supérieur et de l'Oligocène du Bassin de Paris. Bur. Rech. Géol. Minières Mém., 116:1-360.

Chen, Y. Y., Harland, R., Stover, L. E., and Williams, G. L., 1988. Fossil dinoflagellate taxa by Chinese authors, 1978-1984. Can. Tech. Rept. Hydrogr. Ocean Sci., 103:1-40.

Coachman, L. K., and Agaard, K., 1974. Physical oceanography of Arctic and Subarctic seas. In Herman, Y. (Ed.), Marine Geology and Oceanography of the Arctic Seas: New York-Heidelberg-Berlin (Springer-Verlag), 1-72.

Corradini, D., 1978. Dinoflagellate cysts in deep-sea cores from DSDP Site 372, East Menorca Rise. In Ross, D. A., Neprochnov, Y. P., et al., Init. Repts. DSDP., 42: Washington (U.S. Govt. Printing Office), $1225-1230$.

Corradini, D., and Biffi, U., 1988. Etude des Dinokystes à la limite Messinien-Pliocène dans la coupe Cava Serredi, Toscane, Italie. Bull. Centres Rech. Explor.-Prod. Elf-Aquitaine, 12(1):221-236.

Costa, L. I., 1980. Neogene dinocyst stratigraphy in the northern North Sea. Fifth Int. Palynol. Conf. (Cambridge, 1980):92. (Abstract)

Costa, L. I., and Downie, C., 1979. Cenozoic dinocyst stratigraphy of Sites 403 to 406 (Rockall Plateau), IPOD, Leg 48. In Montadert, L., Roberts, D. G., et al., Init. Repts. DSDP, 48: Washington (U.S. Govt. Printing Office), 513-529.

Costa, L. I., and Müller, C., 1978. Correlation of Cenozoic dinoflagellate and nannoplankton zones from the N.E. Atlantic and N.W. Europe. Newsl. Stratigr., 7(2):65-72.

De Coninck, J., 1975. Microfossiles a paroi organique de l'Yprésien du Bassin belge. Serv. Géol. Belgique Prof. Pap., 12:1-151.

1977. Organic-walled microfossils from the Eocene of the Woensdrecht borehole, southern Netherlands. Med. Rijks Geol. Dienst Nieu. Ser., 28:34-63.

1980. Organic-walled microfossils in the clay of Ieper in the Overijse borehole. Bull. Soc. Belge Géol., 89(4):201-215.

De Coninck, J., Geets, S., and Willems, W., 1983. The Mont-Heribu Member: Base of the Ieper Formation in the Belgian Basin. Tertiary Res., 5(2):83-104.

Deflandre, G., 1935. Considérations biologiques sur les microorganismes d'origine planctonique conservés dans les silex de la craie. Bull. Biol. France Belg., 69:213-244.

Dietrich, J. R., Dixon, J., McNeil, D. H., McIntyre, D. J., Snowdon, L. R., and Cameron, A. R., 1989. The geology, biostratigraphy and organic geochemistry of the Natsek E-56 and Edlok N-56 wells, western Beaufort Sea. Geol. Surv. Canada Pap., 89-1G:133-157.

D'Iorio, M. A., 1986. Integration of foraminiferal and dinoflagellate data sets in quantitative stratigraphy of the Grand Banks and Labrador Shelf. Bull. Can. Pet. Geol., 34(2):277-283.

Dixon, J., McNeil, D. H., Dietrich, J. R., Bujak, J. P., and Davies, E. H., 1984. Geology and biostratigraphy of the Dome Gulf et al. Hunt Kopanoar M-13 well, Beaufort Sea. Geol. Surv. Canada Pap., 8213:1-28.

Doerenkamp, A., Jardiné, S., and Moreau, P., 1976. Cretaceous and Tertiary palynomorph assemblages from Banks Island and adjacent Areas (N.W.T.). Bull. Can. Pet. Geol., 24(3):312-417.

Drugg, W. S., 1970. Some new genera, species, and combinations of phytoplankton from the lower Tertiary of the Gulf Coast, U.S.A. Proc. North Am. Paleontol. Conv., Chicago, 1969, G:809-843.

Drugg, W. S., and Loeblich, A. R., Jr., 1967. Some Eocene and Oligocene phytoplankton from the Gulf Coast, U.S.A. Tulane Stud. Geol., 5:181-194.

Duffield, S., and Stein, J. A., 1986. Peridiniacean-dominated dinoflagellate cyst assemblages from the Miocene of the Gulf of Mexico Shelf, offshore Louisiana. Am. Assoc. Stratigr. Palynol. Contrib. Ser., 17:27-46.

Dutta, S. K., and Jain, K. P., 1980. Geology and palynology of the area around Lumshnong, Jaintia Hills, Meghalaya, India. Biol. Mem., $5(1): 56-81$.

Duxbury, S., 1983. A study of dinoflagellate cysts and acritarchs from the lower Greensand (Aptian to lower Albian) of the Isle of Wight, southern England. Palaeontographica, Abt. B, 186:18-80.

Eaton, G. L., 1976. Dinoflagellate cysts from the Bracklesham Beds (Eocene) of the Isle of Wight, southern England. Bull. Br. Mus. Nat. Hist. (Geol.), 26:227-332.

Edwards, L. E., 1984a. Miocene dinocysts from Deep Sea Drilling Project Leg 81, Rockall Plateau, eastern North Atlantic Ocean. In Rob- 
erts, D. G., Schnitker, D., et al., Init. Repts DSDP, 81: Washington (U.S. Govt. Printing Office), 581-594.

1984b. Dinocysts of the Tertiary Piney Point and Old Church formations, Pamunkey River area, Virginia. In Ward, L. W., and Kraft, K. (Eds.), Stratigraphy and Paleontology of the Outcropping Tertiary Beds in the Pamunkey River Region, Central Virginia Coastal Plain (guidebook, Atlantic Coastal Plain Geol. Assoc., 1984 field trip). Atlantic Coastal Plain Geol. Assoc., 124-134.

1986. Late Cenozoic dinoflagellate cysts from South Carolina, U.S.A. In Wrenn, J., et al.(Eds.), Proc. First Symp. on Neogene Dinoflagellate Cyst Biostratigraphy. Am. Assoc. Stratigr. Palynol. Contrib. Ser., 17:47-58.

El-Beialy, S. Y., 1988a. Palynostratigraphy of late Tertiary sediments in Kafr El-Dawar well no. 1, Nile Delta, Egypt. Rev. Micropaléontol., 30(4):249-260.

El-Beialy, S. Y., 1988b. Neogene palynostratigraphy of the El-Qawasim No. 1 well, Nile Delta, Egypt. N. Jb. Geol. Paläont. Mh. 1988, 8: 453-463.

Eldholm, O., Thiede, J., et al., 1987. Proc. ODP, Init. Repts., 104: College Station, TX (Ocean Drilling Program).

Evans, C.D.R., and Hughes, M. J., 1984. The Neogene succession of the South Western Approaches, Great Britain. J. Geol. Soc. (London), 141(2):315-326.

Fechner, G. C., and Mohr, B. A., 1988. Early Eocene spores, pollen and microplankton assemblages from Fehmarn Island, Northern Germany. In Collinson, M. E. (Ed.), Plants and Their Paleoecology: Examples from the Last 80 Million Years. Tert. Res., 9(1-4):147-168.

Fournier, G. R., 1982. Palynostratigraphic analysis of cores from Site 493, Deep Sea Drilling Project Leg 66. In Watkins, J. S., Moore, J. C., et al., Init. Repts. DSDP, 66: Washington (U.S. Govt. Printing Office), 661-670.

Gerlach, E., 1961. Mikrofossilien aus dem Oligozän und Miozän Nordwestdeutschlands, unter besonderer Berücksichtigung der Hystrichosphären und Dinoflagellaten. N. Jb. Geol. Paläontol. Abh., 112:143228.

Gibson, T. G., Andrews, G. W., Bybell, L. M., et al., 1980. Biostratigraphy of the Tertiary strata of the core. In Geology of the Oak Grove Core. Virginia Div. Min. Resour. Publ., 20(2):1-88.

Gocht, H., 1960. Die Gattung Chiropteridium n. gen. (Hystrichosphaeridea) im deutschen Oligozän. Paläont. Zeit., 34:221-232.

Gradstein, F. M., and Srivastava, S. P., 1980. Aspects of Cenozoic stratigraphy and paleoceanography of the Labrador Sea and Baffin Bay. Palaeogeogr., Palaeoclimatol., Palaeoecol., 30:261-295.

Goodman, D. K., 1979. Dinoflagellate "communities" from the lower Eocene Nanjemoy Formation of Maryland, U.S.A. Palynology, 3: 169-180.

Gradstein, F. M., and Srivastava, S. P., 1980. Aspects of Cenozoic stratigraphy and paleoceanography of the Labrador Sea and Baffin Bay. Palaeogeogr., Palaeoclimatol., Palaeoecol., 30:261-295.

Habib, D., 1971. Dinoflagellate stratigraphy across the Miocene-Pliocene boundary, Tabiano stratotype section. In Farinacci, A. (Ed.), Proc. 2nd Planktonic Conf. (Rome, 1970): Rome (Edizioni Tecnoscienza), 1:591-598.

1972. Dinoflagellate stratigraphy, Leg 11, Deep Sea Drilling Project. In Hollister, C. D., Ewing, J. I., et al., Init. Repts. DSDP, 11: Washington (U.S. Govt. Printing Office), 367-425.

1976. Neocomian dinoflagellate zonation in the western North Atlantic. Micropaleontology, 21:373-392.

Haq, B. U., Hardenbol, J., and Vail, P., 1987. Chronology of fluctuating sea levels since the Triassic. Science, 235:1156-1166.

Harland, R., 1978. Quaternary and Neogene dinoflagellate cysts. In Thusu, B. (Ed.), Distribution of Biostratigraphically Diagnostic Dinoflagellate Cysts and Miospores from the Northwest European Continental Shelf and Adjacent Areas. Inst. Kontinentalsokkelundersøkelser Publ., 100:7-17.

Harland, R., 1979. Dinoflagellate biostratigraphy of Neogene and Quaternary sediments at Holes 400/400A in the Bay of Biscay (Deep Sea Drilling Project Leg 48). In Montadert, L., Roberts, D. G., et al., Init. Repts. DSDP, 48: Washington (U.S. Govt. Printing Office), 531-545.

He Cheng-quan and Li Peng, 1981. Late late Oligocene dinoflagellates and acritarchs from North Continental Shelf of South China Sea. In Tert. Palaeontol. North Continent. Shelf South China Sea, 59-72.
Head, M. J., 1988. Palynostratigraphy of the Central Basin (Paleocenelower Eocene?), Spitsbergen. Am. Assoc. Stratigr. Palynol. 21st Annu. Mtg. (Houston). [Prog. and Abstr.].

Head, M. J., Norris, G., Mudie, P. J., and Leg 105 Shipboard Party, 1987. Miocene palynology of ODP Site 645, Leg 105, Baffin Bay. Am. Assoc. Stratigr. Palynol., 20th Annu. Mtg. (Halifax), 24. [Prog. and Abstr]

Heilmann-Clausen, C., 1982. The Paleocene-Eocene boundary in Denmark. Newsl. Stratigr., 11(2):55-63.

1985. Dinoflagellate stratigraphy of the uppermost Danian to Ypressian in the Viborg 1 borehole, central Jylland, Denmark. Danmarks Geol. Unders. Ser., 7(A):1-69.

Herngreen, G.F.W., 1983. Dating Tertiary strata in seven boreholes in the Oldenzaal-Denekamp area (Twente), eastern Netherlands. Mededel. Rijks Geol. Dienst, 37-3:125-153.

1987. Correlation between Miocene beds of The S.E. Netherlands and Italy based on dinoflagellate biozonation. Mededel. Werkgr. Tert. Kwart. Geol., 24(1-2):32-40.

Hinz, K., Schluter, H.-U., Grant, A. C., Srivastava, S. P., Umpleby, D., and Woodside, J., 1979. Geophysical transects of the Labrador Sea: Labrador to southwest Greenland. Tectonophysics, 59:151-183.

Hochuli, P. A., 1978. Palynologische Untersuchungen im Oligozän und Untermiozän der Zentralen und Westlichen Paratethys. Beitr. Paläontol. Österreich, 4:1-132.

Ioakim, C., 1979. Etude comparative des dinoflagellés du Tertiaire inférieur de la mer du Labrador et de la mer Nord [Ph.D. dissert.]. Univ. Pierre et Marie Curie, Paris, 1-204.

Ioannides, N. S., and McIntyre, D. J., 1980. A preliminary palynological study of the Caribou Hills outcrop section along the Mackenzie River, District of Mackenzie. Geol. Surv. Can. Pap., 80-1A:197208.

Islam, M. A., 1983a. Dinoflagellate cysts from the Eocene cliff sections of the Isle of Sheppay, southeast England. Rev. Micropaléontol., 25: 231-250.

1983b. Dinoflagellate cyst taxonomy and biostratigraphy of the Eocene Bracklesham Group in southern England. Micropaleontology, 29:328-353

1984. A study of early Eocene palaeoenvironments in the Isle of Sheppey as determined from microplankton assemblage composition. Tert. Res., 6(1):11-21.

Jain, K. P., 1977. Additional dinoflagellates and acritarchs from Gray Shale Member of Dalmiapuram Formation, south India. Palaeobotanist, 24:170-194.

Jain, K. P., and Tandon, K. K., 1981. Dinoflagellate and acritarch biostratigraphy of the middle Eocene rocks of a part of southwestern Kachchh, India. J. Palaeontol. Soc. India, 26:6-21.

Jan du Chêne, R., 1977. Etude palynologique du Miocène supérieur Andalou (Espagne). Rev. Española Micropaleontol., 9:97-114.

Jarvis, I., and Tocher, B., 1985. Neogene and Quaternary dinoflagellate biostratigraphy of the eastern equatorial Pacific: Deep Sea Drilling Project Leg 85. In Mayer, L., Theyer, F., et al., Init. Repts. DSDP, 85: Washington (U.S. Govt. Printing Office), 407-412.

Jiabo, 1978. On the Paleogene dinoflagellates and acritarchs from the coastal region of Bohai. Nanking Inst. Geol. Palaeontol., Acad. Sinica, 1-190.

King, C., 1983. Cainozoic micropalaeontological biostratigraphy of the North Sea. Inst. Geol. Sci. (Great Britain) Rept., 82/7:1-40.

Krasheninnikov, V. A., 1979. Stratigraphy and planktonic foraminifers of Cenozoic deposits of the Bay of Biscay and Rockall Plateau, DSDP Leg 48. In Montadert, L., Roberts, D. G., et al., Init. Repts. DSDP, 48: Washington (U.S. Govt. Printing Office), 431-450.

Kristoffersen, F. F., 1972. Foraminiferzonering i det jyske Miocaen. Dansk Geol. Foren. Arsskrift (1971), 79-85.

Larsen, L. M., Rex, D. C., and Secher, K., 1983. The age of carbonatites, kimberlites, and lamprophyres from southern West Greenland: recurrent alkaline magmatism during 2500 million years. Lithos, 16: 215-221.

LeNoir, E. A., and Hart, G. F., 1986. Burdigalian (Early Miocene) dinocysts from offshore Louisiana. Am. Assoc. Stratigr. Palynol. Contrib. Ser., 17:59-82.

Lentin, J. K., and Williams, G. L., 1977. Fossil dinoflagellates: index to genera and species (1977 edition). Bedford Inst. Oceanogr. Rept. Ser., B1-R-77-8:1-209. 
1985. Fossil dinoflagellates: index to genera and species (1985 ed.). Can. Tech. Rept. Hydrogr. Ocean Sci., 60:1-451

Lentin, J. K., Williams, G. L., and Fensome, R. A., 1987. Sumatradinium: A stratigraphically useful dinoflagellate genus from the Neogene sediments of offshore eastern Canada. Am. Assoc. Stratigr. Palynol., 20th Annu. Mtg., 104. [Program and Abstr.].

Liengjarern, M., Costa, L., and Downie, C., 1980. Dinoflagellate cysts from the upper Eocene-lower Oligocene of the Isle of Wight. Palaeontology, 23:475-499.

Londeix, L., and Jan du Chêne, R., 1988. Ectosphaeropsis, nouveau genre de dinoflagellé de la région stratotypique du Burdigalien bordelais (France). Bull. Centres Rech. Explor.-Prod. Elf-Aquitaine, 12(1):251-265.

Lucas-Clark, J., 1987. Wigginsiella n. gen., Spongodinium, and Apteodinium as members of the Aptiana-Ventriosum complex (fossil dinophyceae). Palynology, 11:155-184.

Manum, S. B., 1976. Dinocysts in Tertiary Norwegian-Greenland Sea sediments (Deep Sea Drilling Project Leg 38), with observations on palynomorphs and palynodebris in relation to environment. In Talwani, M., Udintsev, G., et al., Init. Repts. DSDP, 38: Washington (U.S. Govt. Printing Office), 897-919.

1979. Two new Tertiary dinocyst genera from the Norwegian Sea; Lophocysta and Evittosphaerula. Rev. Palaeobot. Palynol., 28: 237-248.

Manum, S. B., and Throndsen, T., 1986. Age of Tertiary formations on Spitsbergen. Polar Res., 4:103-131.

Manum, S. B., Boulter, M. C., Gunnarsdottir, H., Rangnes, K., and Scholze, A., in press. Palynology of the Eocene to Miocene sedimentary sequence of ODP Leg 104 (Norwegian Sea). In Eldholm, O., Thiede, J., et al., Proc. ODP, Sci. Results, 104: College Station, TX (Ocean Drilling Program).

Martini, E., 1971. Standard Tertiary and Quaternary calcareous nannoplankton zonation. Proc. 2nd Planktonic Conf. (Rome, 1970), 2: 739-785.

Matsuoka, K., 1974. Some plant microfossils from the Miocene Fujiwara Group, Nara, central Japan. Trans. Proc. Palaeontol. Soc. Japan, 94:319-340.

1983. Late Cenozoic dinoflagellates and acritarchs in the Niigata District, central Japan. Palaeontographica, Abt. B, 187:89154.

1985. Organic-walled dinoflagellate cysts from surface sediments of Nagasaki Bay and Senzaki Bay, West Japan. Bull. Fac. Liberal Arts, Nagasaki Univ., 25(2):21-115.

1987. Organic-walled dinoflagellate cysts from surface sediments of Akkeshi Bay and Lake Saroma, north Japan. Bull. Fac. Liberal Arts, Nagasaki Univ., 28(1):35-123.

Matsuoka, K., Bujak, J. P., and Shimazaki, T., 1987. Late Cenozoic dinoflagellate cyst biostratigraphy from the west coast of north Japan. Micropaleontology, 33(3):214-229.

Matsuoka, K., and Bujak, J. P., 1988. Cenozoic dinoflagellate cysts from the Navarin Basin, Norton Sound and St. George Basin, Bering Sea. Bull. Fac. Lib. Arts, Nagasaki Univ., Nat. Sci., 29(1):1147.

McNeil, D. H., Ioannides, N. S., and Dixon, J., 1982. Geology and biostratigraphy of the Dome Gulf et al. Ukalerk C-50 well, Beaufort Sea. Geol. Surv. Can. Pap., 80-32:1-16.

Michoux, D., 1985. Palynostratigraphie de L'Eocène de Montfort-enChalosse (Landes, France). Rev. Micropaleontol., 28(2):138-152.

Morgenroth, P., 1966. Mikrofossilien und Konkretionen des nordwesteuropäischen Untereozäns. Palaeontographica, Abt. B, 119:1-53.

Morzadec-Kerfourn, M.-T., 1988. Paléoclimats et paléoenvironnements du Tardiglaciaire au Récent, en Méditerranée orientale, a l'est du delta du Nil; l'apport des microfossiles a membrane organique. Bull. Centres Rech. Explor.-Prod. Elf-Aquitaine, 12(1):267-275.

Mudie, P. J., 1987. Palynology and dinoflagellate biostratigraphy of Deep Sea Drilling Project Leg 94, Sites 607 and 611, North Atlantic Ocean. In Ruddiman, W. F., Kidd, R. B., Thomas, E., et al., Init. Repts. DSDP, 94 (Pt. 2): Washington (U.S. Govt. Printing Office), 785-812.

in press. Palynology and dinocyst biostratigraphy of the late Miocene to Pleistocene, Norwegian Sea, ODP Leg 104, Sites 642 to 644. In Eldholm, O., Thiede, J., et al., Proc. ODP, Sci. Results, 104: College Station, TX (Ocean Drilling Program).
Mudie, P. J., and Helgason, J., 1983. Palynological evidence for Miocene climatic cooling in eastern Iceland about $9.8 \mathrm{Myr}$ ago. Nature, 303(5919):689-692.

Mudie, P. J., and Short, S. K., 1985. Marine palynology of Baffin Bay. In Andrews, J. T. (Ed.), Quaternary Environments, eastern Canadian Arctic, Baffin Bay and Western Greenland: London (Allen and Unwin), 263-307.

Müller, C., 1976. Tertiary and Quaternary calcareous nannoplankton in the Norwegian-Greenland Sea, DSDP Leg 38. In Talwani, M., Udintsev, G., et al., Init. Repts. DSDP, 38: Washington (U.S. Govt. Printing Office), 823-841.

1979. Calcareous nannofossils from the North Atlantic (Leg 48). In Montadert, L., Roberts, D. G., et al., Init. Repts. DSDP, 48: Washington (U.S. Govt. Printing Office), 589-639.

1985. Biostratigraphic and paleoenvironmental interpretation of the Goban Spur region based on a study of calcareous nannoplankton. In Gracianski, P. C. de, Poag, C. W., et al., Init. Repts. DSDP, 80(Pt.1): Washington (U.S. Govt. Printing Office), 573-599.

Nielsen, O. B., Baumann, J., Zhang D., Heilmann-Clausen, C., and Larsen, G., 1986. The Tertiary section of borehole D.G.I. 83101, Østerrenden, Store Bælt, Denmark. Møller, J. T. (Ed.), Twenty-five years of geology in Aarhus. Geol. Inst. Aarhus Univ. Geoskr., 24(1986):235253.

Norris, G., 1986. Systematic and stratigraphic palynology of Eocene to Pliocene strata in the Imperial Nuktak C-22 Well, Mackenzie Delta Region, District of Mackenzie, N.W.T. Geol. Surv. Can. Bull., 340: 1-89.

Partridge, A. D., 1978. Palynology of late Tertiary at Site 365, Leg 40, Deep Sea Drilling Project. In Bolli, H. M., Ryan, W.B.F., et al., Init. Repts. DSDP, 40: Washington (U.S. Govt. Printing Office), 953-961.

Piasecki, S., 1980. Dinoflagellate cyst stratigraphy of the Miocene Hodde and Gram formations, Denmark. Geol. Surv. Denmark Bull., 29: 53-76.

Piper, D.J.W., Mudie, P. J., Fader, G. B., et al., in press. Quaternary geology. In Keen, M. J., and Williams, G. L. (Eds.), Geology of Canada Ser. Offshore East Coast.

Powell, A. J., 1983. Miocene dinoflagellate cysts of the Piedmont Tertiary Basin, Italy [Ph.D. dissert.]. Univ. of Sheffield, England. [Not seen]

1986a. Latest Palaeogene and earliest Neogene dinoflagellate cysts from the Lemme section, northwest Italy. Am. Assoc. Stratigr. Palynol. Contr. Ser., 17:83-104.

1986b. A dinoflagellate cyst biozonation for the late Oligocene to middle Miocene succession of the Langhe region, northwest Italy. Am. Assoc. Stratigr. Palynol. Contr. Ser., 17:105-128.

1986c. The stratigraphic distribution of late Miocene dinoflagellate cysts from the Castellanian superstage stratotype, northwest Italy. Am. Assoc. Stratigr. Palynol. Contr. Ser., 17:129-150. 1988a. A preliminary investigation into the Neogene dinoflagellate cyst biostratigraphy of the British Southwestern Approaches. Bull. Centres Rech. Explor.-Prod. Elf-Aquitaine, 12(1):277-311.

1988b. A modified dinoflagellate cyst biozonation for latest Palaeocene and earliest Eocene sediments from the central North Sea. Rev. Palaeobot. Palynol., 56(3-4):327-344.

Riediger, C. L., Bustin, R. M., and Rouse, G. E., 1984. New evidence for the chronology of the Eurekan Orogeny from south-central Ellesmere Island. Can. J. Earth Sci., 21(11):1286-1295.

Rolle, F., 1985. Late Cretaceous-Tertiary sediments offshore central West Greenland: lithostratigraphy, sedimentary evolution, and petroleum potential. Can. J. Earth Sci., 22:1001-1019.

Sarjeant, W.A.S., 1981. A restudy of some dinoflagellate cyst holotypes in the University of Kiel Collections II. The Eocene holotypes of Barbara Klumpp (1953); with a revision of the genus, Cordosphaeridium Eisenack, 1963. Meyniana, 33:97-132.

1983. A restudy of some dinoflagellate cyst holotypes in the University of Kiel Collections IV. The Oligocene and Miocene holotypes of Dorothea Maier (1959). Meyniana, 35:85-137.

1984. Restudy of some dinoflagellate cysts from the Oligocene and Miocene of Germany. J. Micropalaeontol., 3(2):73-94.

Scherer, F., 1961. Hystricosphaerideen und Dinoflagellaten aus der oligozänen, subalpinen Molasse der Entlebuchs und des Thunerseegebiets. Ver. Schweizer. Petrol.-Geol. u-Ing. Bull., 27(73):15-16. 
Schrader, H.-J., and Fenner,J., 1976. Norwegian Sea Cenozoic diatom biostratigraphy and taxonomy. Part 1, Norwegian Sea Cenozoic diatom biostratigraphy. In Talwani, M., Udintsev, G., et al., Init. Repts. $D S D P$, 38: Washington (U.S. Govt. Printing Office), 921-962.

Scott, D. B., MacKinnon, K. D., and Baki, V., 1987. Arctic Ocean benthonic foraminifera, stable-isotope stratigraphy and Quaternary paleoenvironment. INQUA '87. [Program and Abstracts]

Shimakura, M., Nishida, S., and Matsuoka, K., 1971. Some plant microfossils from the Yamato-tai, Sea of Japan. Nara Univ. Education, Nat. Sci. Bull., 20:63-70.

Snyder, S. W., and Waters, V. J., 1985. Cenozoic planktonic foraminiferal biostratigraphy of the Goban Spur region, Deep Sea Drilling Project Leg 80. In Gracianski, P. C. de, Poag, C. W., et al., Init. Repts. DSDP, 80 (Pt.1): Washington (U.S. Govt. Printing Office), 439-461.

Srivastava, S. P., 1978. Evolution of the Labrador Sea and its bearing on the early evolution of the North Atlantic. Geophys. J. R. Astron. Soc., 52:313-357.

Srivastava, S. P., Falconer, R.K.H., and MacLean, B., 1981. Labrador Sea, Davis Strait, Baffin Bay: Geology and Geophysics, a review. Can. Soc. Petrol. Geol. Mem. 7:333-398.

Srivastava, S. P., Arthur, M., Clement, B., et al., 1987. Proc. ODP, Init. Repts., 105: College Station, TX (Ocean Drilling Program).

Staplin, F. L. (Ed.), 1976. Tertiary biostratigraphy, Mackenzie Delta Region, Canada. Bull. Can. Pet. Geol., 24(1):117-136.

Stein, J. A., Damassa, S. P., and Duffield, S. L., 1987. Oligocene-Miocene biostratigraphy of DSDP Site 369: integration of dinoflagellate cyst occurrences. Am. Assoc. Stratigr. Palynol., 20th Annu. Mtg. [Program and Abstracts], 136.

Stover, L. E., 1977. Oligocene and early Miocene dinoflagellates from Atlantic Corehole 5/5B, Blake Plateau. Am. Assoc. Stratigr. Palynol. Contrib. Ser., 5A:66-89.

Sung Zhi-chen, He Cheng-quan, Quan Ze-shu, et al. ("Jiabo"), 1978. On the Paleogene dinoflagellates and acritarchs from the coastal region of Bohai: Nanking (Nanking-Inst. Geol. Palaeontol., Acad. Sinica, 1-190 (in Chinese with English abstract).

Takayama, T., and Sato, T., 1987. Coccolith biostratigraphy of the North Atlantic Ocean, Deep Sea Drilling Project, Leg 94. In Ruddiman, W. F., Kidd, R. B., Thomas, E., et al., Init. Repts. DSDP, 94 (Pt. 2): Washington (U.S. Govt. Printing Office), 651-702.

Turon, J.-L., and Londeix, L., 1988. Les assemblages de kystes de Dinoflagellés en Méditerranée occidentale (Mer d'Alboran). Mise en Evidence de l'évolution des paléoenvironnements depuis le dernier maximum glaciaire. Bull. Centres Rech. Explor.-Prod. Elf-Aquitaine, 12(1):313-344.

Van Couvering, J. A., Aubry, M-P., Berggren, W. A., Bujak, J. P., Naeser, C. W., and Wieser, T., 1981. The Terminal Eocene event and the Polish connection. Palaeogeogr., Palaeoclimatol., Palaeoecol., $36: 321-362$.
Wall, D., and Dale, B., 1968. Early Pleistocene dinoflagellates from the Royal Society Borehole at Ludham, Norfolk. New Phytol., 67:315326.

Watts, A. B., and Steckler, M. S., 1979. Subsidence and eustasy at the continental margin of eastern North America. In Talwani, M., Hay, W. W., and Ryan, W.B.F. (Eds.), Deep Drilling Results in the Atlantic Ocean: Continental Margins and Paleoenvironment: Washington (Am. Geophys. Union), Maurice Ewing Ser., 3:218-234.

Williams, G. L., 1975. Dinoflagellate and spore stratigraphy of the Mesozoic-Cenozoic, offshore eastern Canada. Geol. Surv. Canada Pap., 74-30(2):107-161.

1978. Palynological biostratigraphy, Deep Sea Drilling Project, Sites 367 and 370. In Lancelot, Y., Seibold, E., et al., Init. Repts DSDP, 41: Washington (U.S. Govt. Printing Office), 783-815.

Williams, G. L., and Brideaux, W. W., 1975. Palynologic analyses of upper Mesozoic and Cenozoic rocks of the Grand Banks, Atlantic continental margin. Geol. Surv. Can. Bull., 236:1-163.

Williams. G. L., and Bujak, J. P., 1977a. Distribution patterns of some North Atlantic Cenozoic dinoflagellate cysts. Mar. Micropalaeontol., 2:223-233.

1977b. Cenozoic palynostratigraphy of offshore eastern Canada. Am. Assoc. Stratigr. Palynol., Contr. Ser., 5A:14-47.

Williams, V. E., 1986. Palynological study of the continental shelf sediments of the Labrador Sea [Ph.D. dissert.]. Univ. of British Columbia, 1-216.

Wolfe, J. A., 1985. Distribution of major vegetational types during the Tertiary. In Sundquist, E. T., and Broecker, W. A. (Eds.), The Carbon Cycle and Atmospheric $\mathrm{CO}_{2}$. Am. Geophys. Union Monogr., 32:357-375.

Wrenn, J. H., and Kokinos, J. P., 1986. Preliminary comments on Miocene through Pleistocene dinoflagellate cysts from De Soto Canyon, Gulf of Mexico. Am. Assoc. Stratigr. Palynol. Contr., 17:169-225.

Wrenn, H. J., and Satchell, L. S., 1988. Cenozoic palynostratigraphy of Exxon Core Hole 32-45 from the West Florida carbonate platform, Gulf of Mexico: Integration with a seismic stratigraphic model. $\mathrm{Am}$. Assoc. Stratigr. Palynol., 21st Annu. Mtg. (Houston) [Abstract].

Young, F. G., and McNeil, D. H., 1984. Cenozoic stratigraphy of the Mackenzie Delta, Northwest Territories. Geol. Surv. Can. Bull., $336: 1-63$.

Yun, H., 1988. Miocene dinoflagellate cysts from the "E" borehole in the Pohang Basin, Korea. Proc. 7th Int. Palynol. Congress (Brisbane). [Abstract], 184.

Date of initial receipt: 23 May 1988

Date of acceptance: 7 February 1989

Ms no: 105B-137 


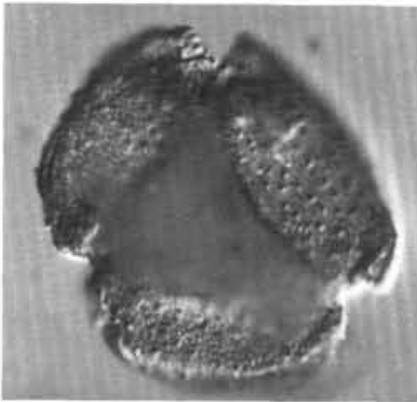

1

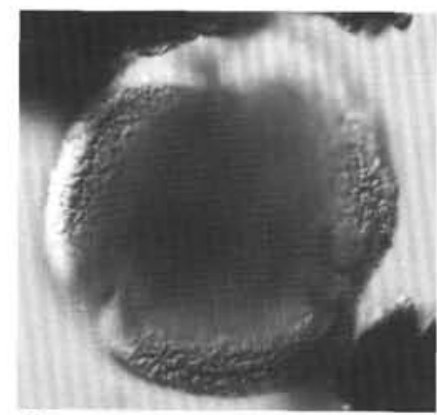

5

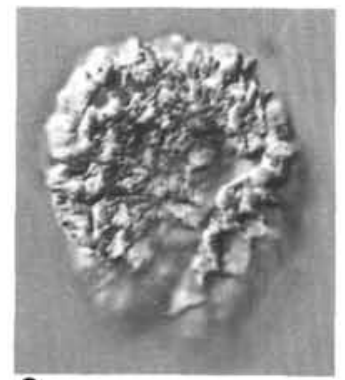

9

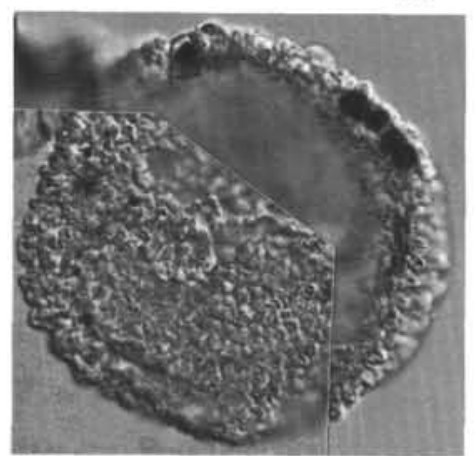

15

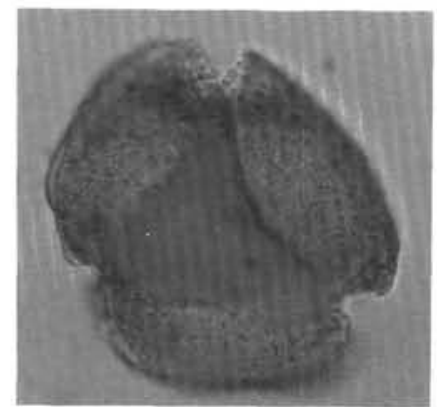

2

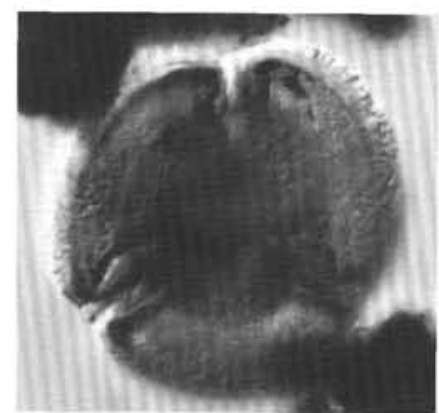

6

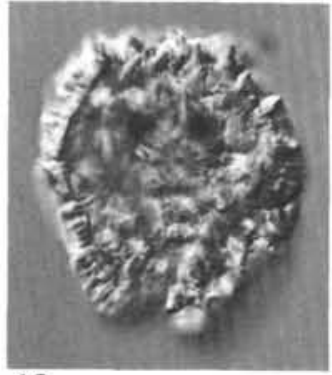

10

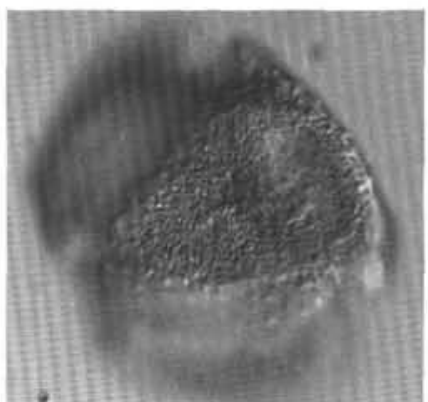

3

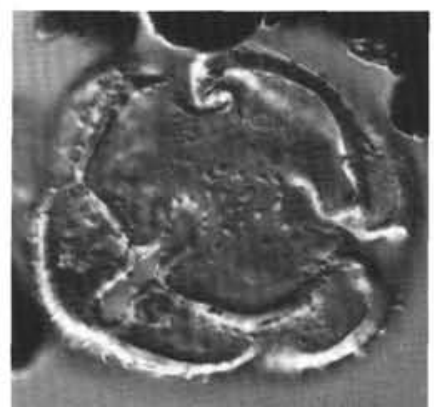

7

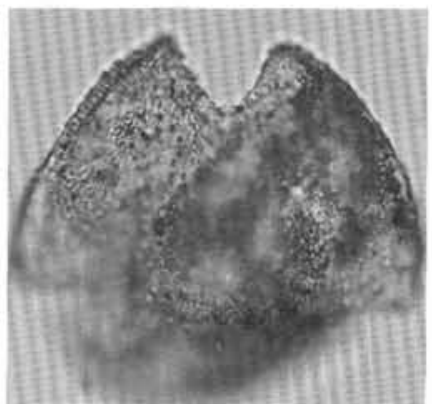

4

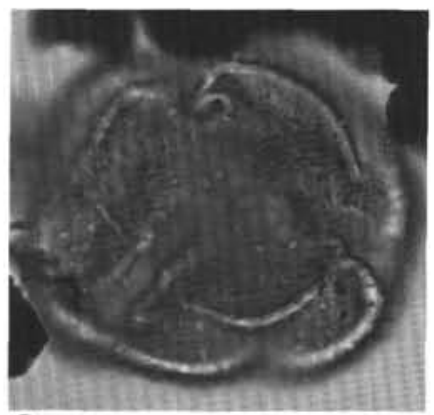

8

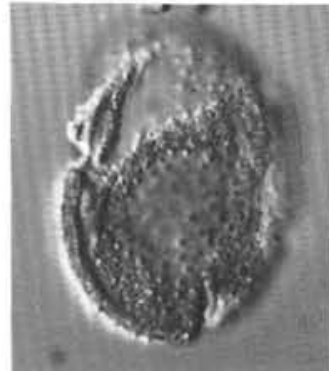

11

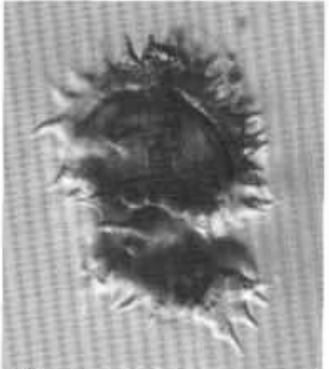

12

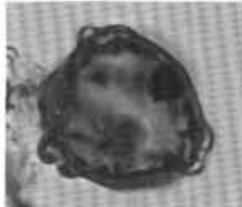

13

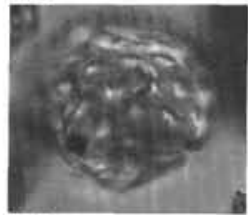

14

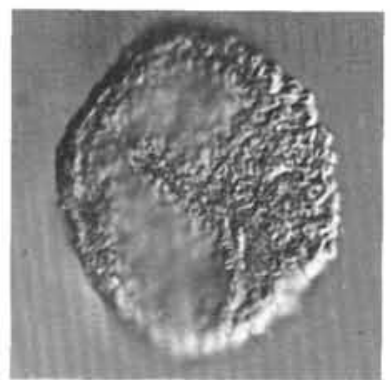

16

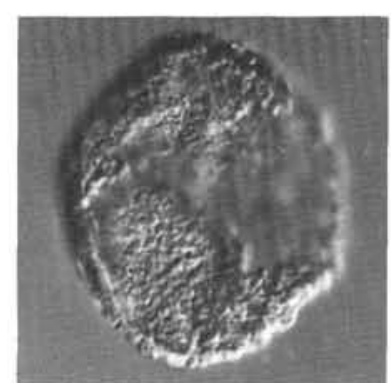

17

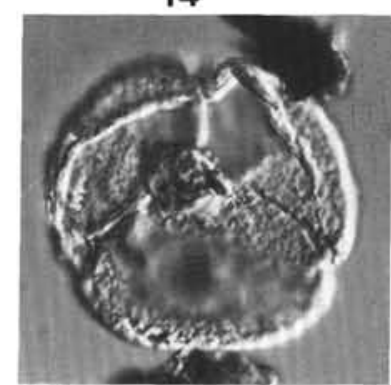

18

Plate 1. (Figs. 1,3,5-12,14-18, IC.; Figs. 2,4,13, BF.). 1-4, 11. Lonicera sp. 1-3, Sample -34R, CC (5) U42/2, dia., $49 \mu \mathrm{m}$ (1,2 mf, 3, uf). 4. Sample -37R, CC (4) T5/0, dia., $57 \mu \mathrm{m}$. 11. Sample -30R, CC (4) L42/1, dia., $45 \mu \mathrm{m}$ (uf). 5,6. Tricolp(or)ate (vermiculate) sp. 5,6. Sample -62R-1, 138-141 $\mathrm{cm}$, (4) E27/0, dia., $54 \mu \mathrm{m}$ (5, uf, 6, mf). 7,8. Saxonipollis sp. 7,8. Sample -63R-6, 16-19 cm (5) N30/4, dia., (of tetrad), 58 $\mu \mathrm{m}$ (8, hf, 7, lrf). 9,10. Persicarioipollis sp. 9,10. Sample -61R-5, 36-39 cm (4) T33/4, dia., $40 \mu \mathrm{m}(9, \mathrm{hf}, 10$, Irf). 12. Lophate Compositae sp. 12. Sample -28R-2, 8$11 \mathrm{~cm}$ (5) A38/3, dia. (including spines), $46 \mu \mathrm{m}$. 13. Betula sp. 13. Sample -26R-2, 34-37 cm (5) J48/4, dia., $24 \mu \mathrm{m}$. 14. Chenopodiaceae/Amaranthaceae sp. 14. Sample -60R-4, 88-91 cm (5) J45/0, dia., $24 \mu \mathrm{m}$. 15. Tsuga sp. 15. Sample -60R, CC (5) U26/0, dia., $74 \mu \mathrm{m}$, (split focus, upper right, hf, lower left, lrf). 16,17. Sciadopityspollenites serratus. 16,17. Sample $-75 \mathrm{R}-4,15-18 \mathrm{~cm}(4) \mathrm{J} 46 / 3$, dia., $43 \mu \mathrm{m}$. 18. Fagus sp. 18. Sample
$-55 \mathrm{R}-5,17-20 \mathrm{~cm}$ (5) R17/2, dia., $42 \mu \mathrm{m}$. 


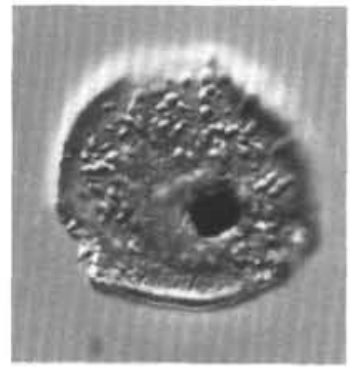

1

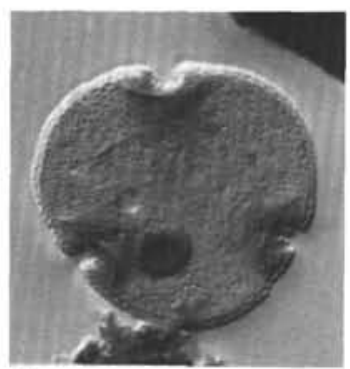

6

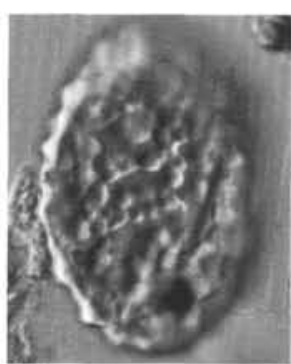

11

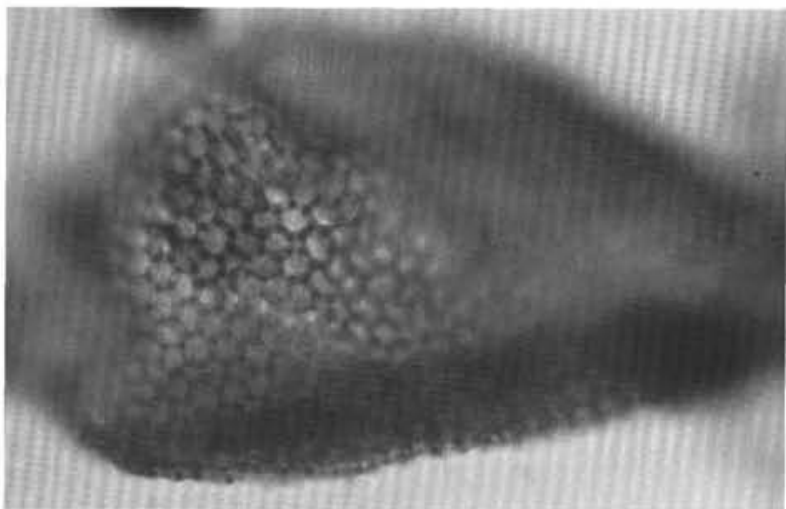

16

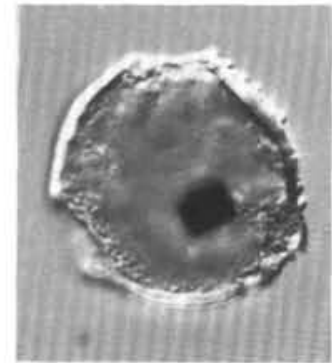

2

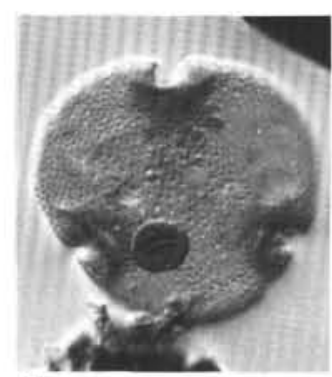

7

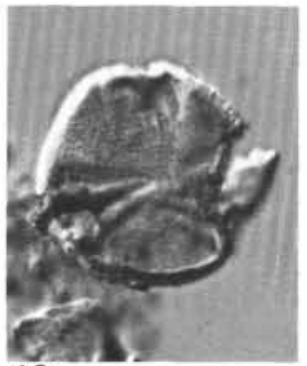

12

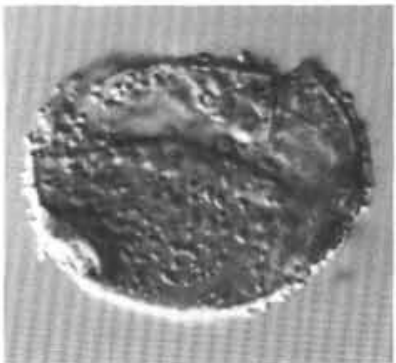

3

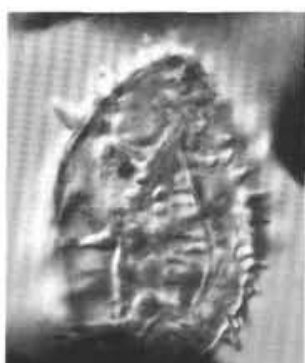

8

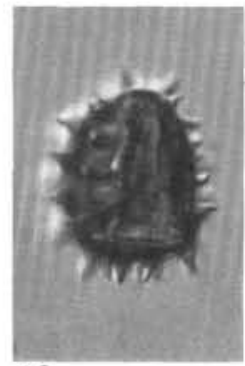

13

9

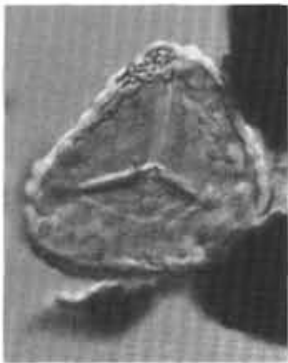

4
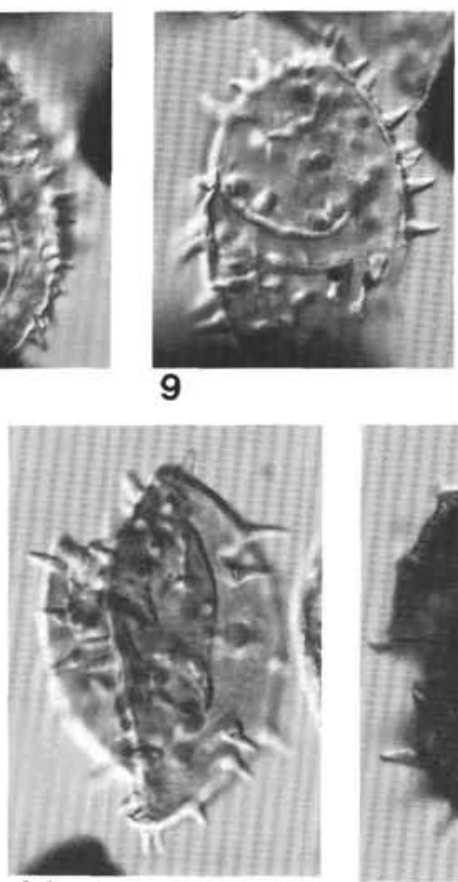

14

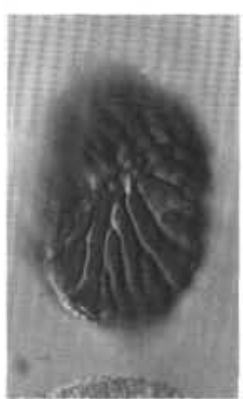

17

15

18

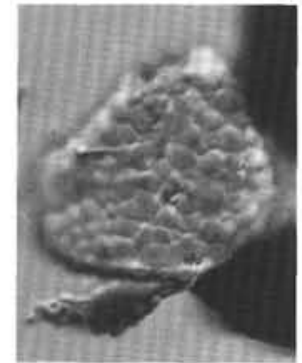

5

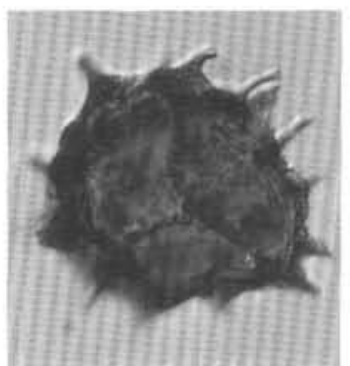

10
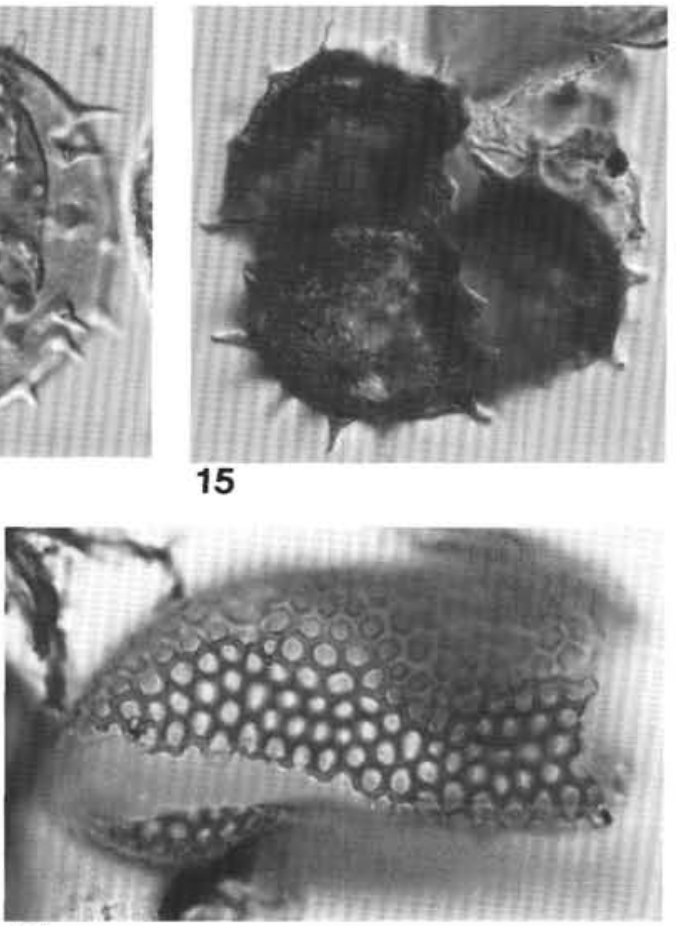

Plate 2. (All figures, IC). 1-3. cf. Weigela sp. (note convex spines). 1,2. Sample -76R-2, 134-137 cm (4) L17/2, dia., 33 $\mu \mathrm{m}$. 3. Sample -75R-4, 15$18 \mathrm{~cm}$ (4) G23/0, dia., $45 \mu \mathrm{m}$. 4,5. Sample -37R, CC (5) T39/3, dia., $32 \mu \mathrm{m}(4,1 \mathrm{f}, 5$, hf). 6,7. Tilia sp. 6,7. Sample -73R, CC (5) W12/4, dia., 38 $\mu \mathrm{m}$ (7, hf, 6, lrf). 8,9,14. Nuphar sp. 8,9. Sample -73R-4, 48-52 cm (4) R48/4, length (excl. spines), $45 \mu \mathrm{m}$ (9, hf, proximal, 8 lf distal). 14. Sample $-30 \mathrm{R}, \mathrm{CC}$ (4) W43/1, length (excl. spines), $45 \mu \mathrm{m}$. 10,15. Selaginella sp. 10. Sample $-38 \mathrm{R}-5,25-28 \mathrm{~cm}(4) \mathrm{N} 37 / 4$, dia. (excl. spines), $34 \mu \mathrm{m} .15$. Sample -38R-5, 25-28 cm (5) B50/0, dia. (of tetrad, excl. spines), $57 \mu \mathrm{m}$. 11. Hazaria sp. 11. Sample $-63 \mathrm{R}-6,16-19 \mathrm{~cm}(5) \mathrm{E} 35 / 3,1$ length, $40 \mu \mathrm{m}$. 12. Nyssa sp. 12. Sample $-40 \mathrm{R}-4,28-33 \mathrm{~cm}$ (5) R34/2, dia., $28 \mu \mathrm{m}$. 13. Compositae sp. 13. Sample $-26 \mathrm{R}-2,34-37 \mathrm{~cm}$ (5) T15/1, dia. (incl. spines), 29 $\mu \mathrm{m}$. 16. Reticulosporis sp. 1. 16. Sample -37R, CC (4) F37/1, length, $83 \mu \mathrm{m}$ (note tectate wall and columellae). 17. Radialisporis radiatus. 17. Sample $-30 \mathrm{R}, \mathrm{CC}$, (4) B $42 / 0$, dia., $37 \mu \mathrm{m}$. 18. Reticulosporis sp. 2. 18. Sample $-38 \mathrm{R}-5,25-28 \mathrm{~cm}$, (4) D29/0, length, $83 \mu \mathrm{m}$ (lacunae, about $3.5 \mu \mathrm{m}$, no columellae seen). 


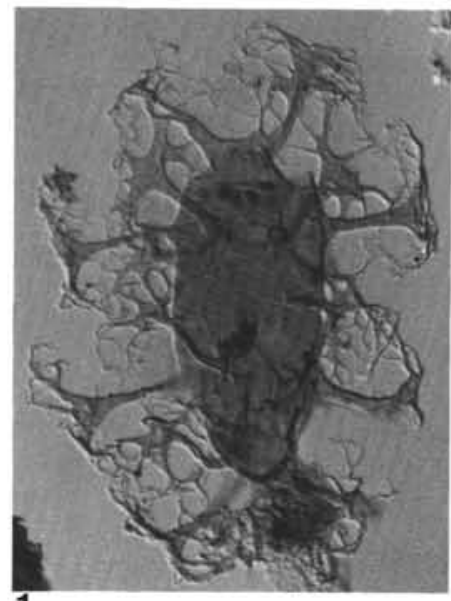

1

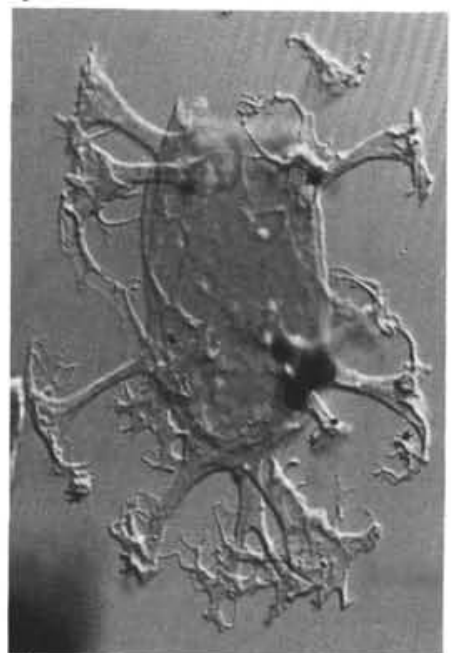

5

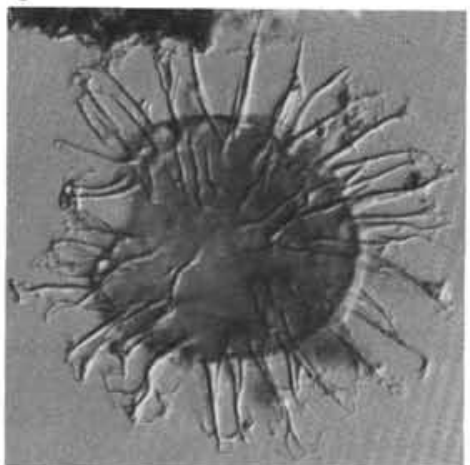

11

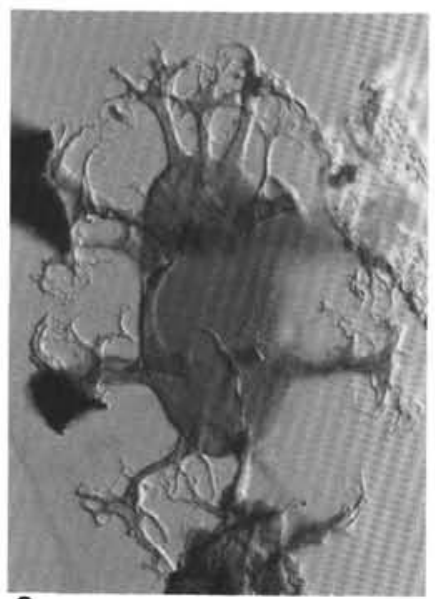

2

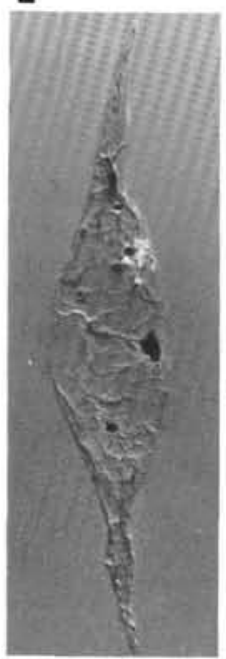

6

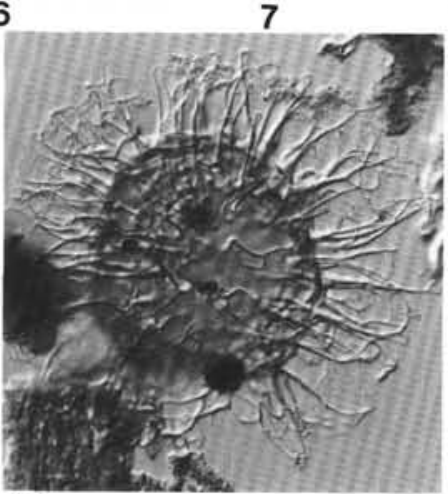

12

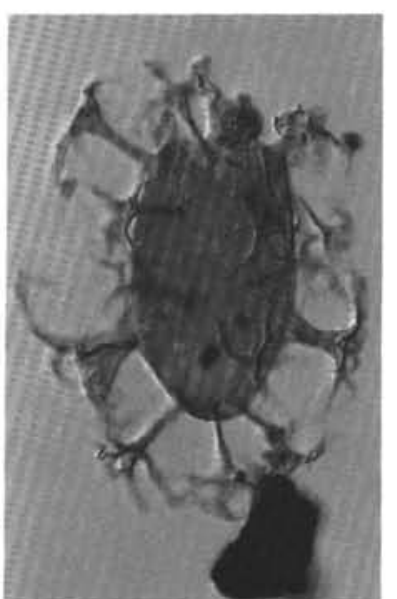

3
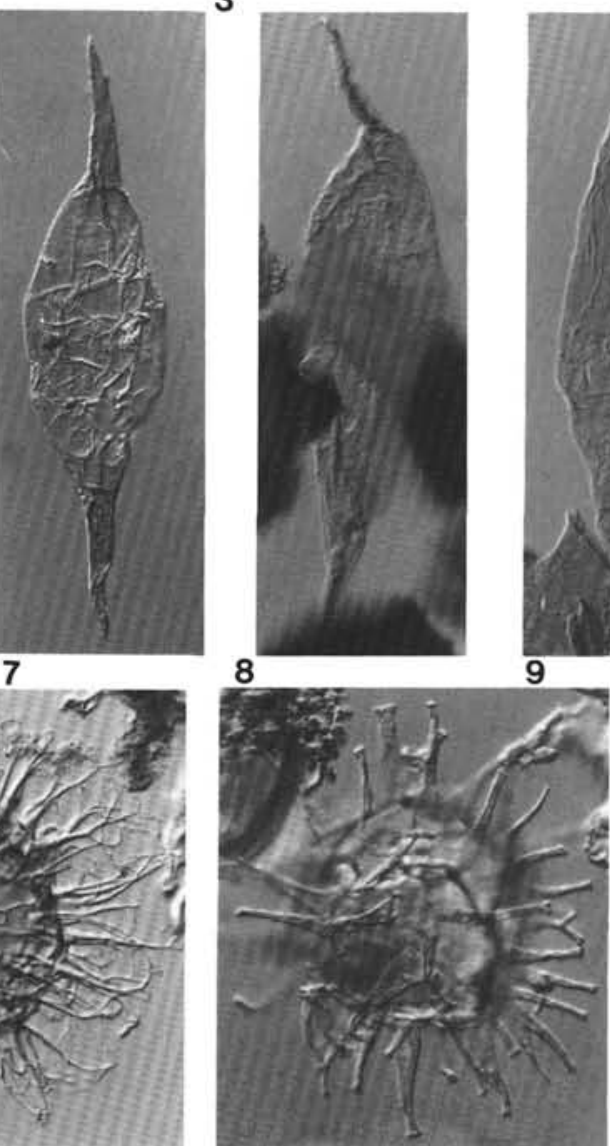

13

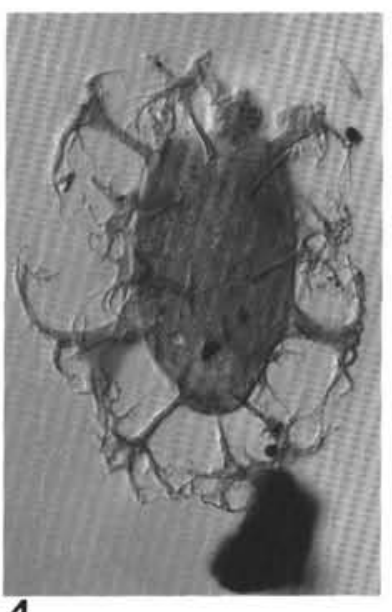

4
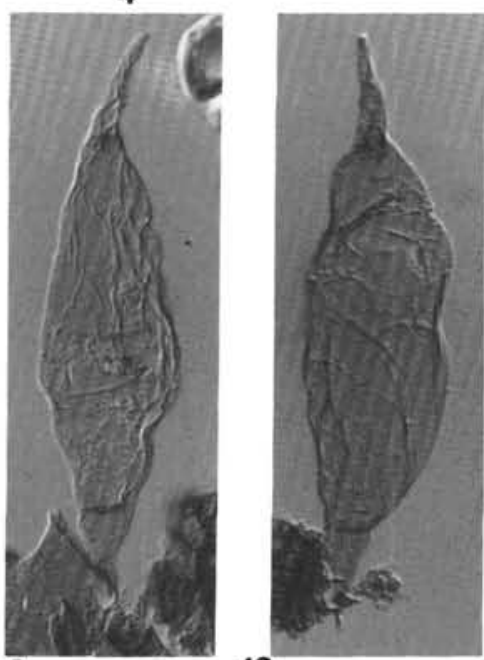

10

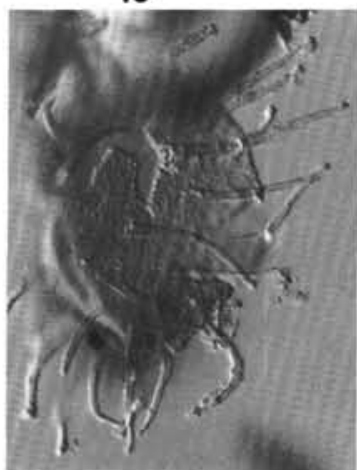

14

Plate 3. (All figures, IC). 1-5. Distatodinium paradoxum. 1. Sample -78R, CC, (4) J23/2, body length, $66 \mu \mathrm{m}$. 2. Sample -78R, CC, (4) L40/0, body length, $59 \mu \mathrm{m}$. 3,4. Sample -78R, CC, (4) G20/0, body length, $56 \mu \mathrm{m}(3$, lf; 4 , hf). 5. Sample $-69 \mathrm{R}, \mathrm{CC},(5) \mathrm{G} 40 / 1$, body length, $57 \mu \mathrm{m}$. 6,7. Palaeocystodinium golzowense. 6. Sample -61R-5, 36-39 cm (4) F37/0, length, $138 \mu \mathrm{m}$. 7. Sample -73R, CC, (5) N35/0, length, 148 $\mu \mathrm{m}$. 8-10. Palaeocystodinium cf. golzowense sensu Powell, 1986b. 8. Sample -48R, CC, (5) K21/0, length, $128 \mu \mathrm{m}$. 9. Sample $-28 \mathrm{R}-2,8-11 \mathrm{~cm}(5) \mathrm{Q} 23 / 1$, length, $111 \mu \mathrm{m}$. 10. Sample $-28 \mathrm{R}-2,8-11 \mathrm{~cm}(5) \mathrm{M} 11 / 3$, length, $117 \mu \mathrm{m}$. 11,12. Impletosphaeridium sp. 1. 11. Sample $-40 \mathrm{R}-4,28-33 \mathrm{~cm}(5) \mathrm{O} 16 / 0$, body dia., $42 \mu \mathrm{m}(\mathrm{hf}) .12$. Sample $-40 \mathrm{R}-4,28-33 \mathrm{~cm}(5) \mathrm{N} 28 / 4$, body dia., $41 \mu \mathrm{m}$. 13. Dapsilidinium pseudocolligerum. 13. Sample $-48 \mathrm{R}, \mathrm{CC},(5) \mathrm{O} 47 / 2$, body dia., $37 \mu \mathrm{m}$ (hf). 14. Lingulodinium machaerophorum. 14. Sample -77R, CC, (5) M21/4, body dia., $50 \mu \mathrm{m}$ (hf). 


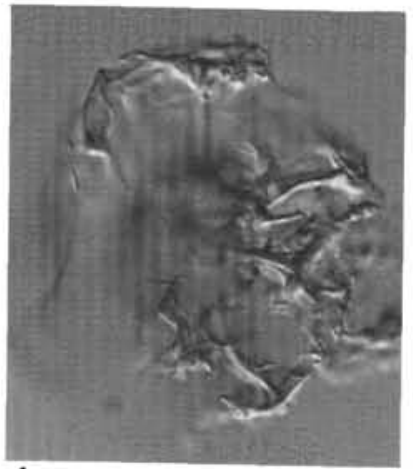

1

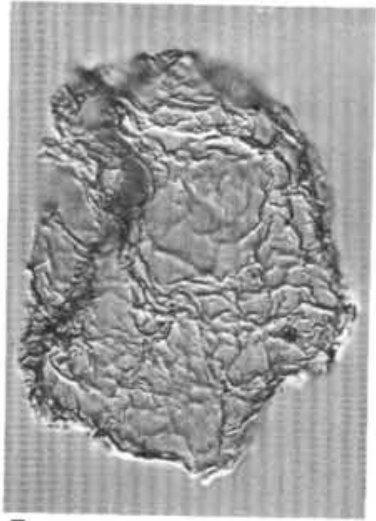

5

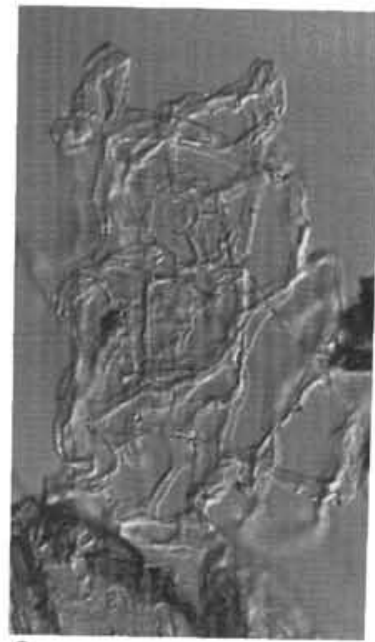

9

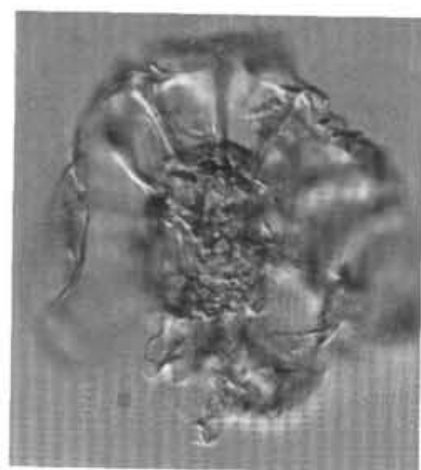

2

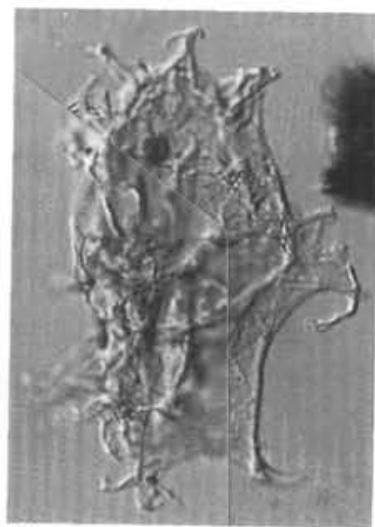

6

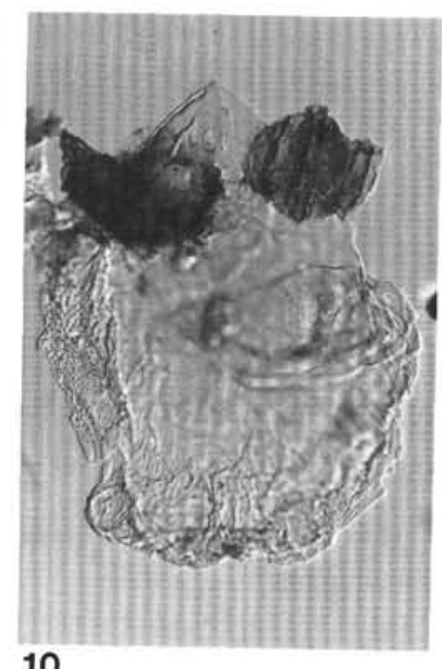

10

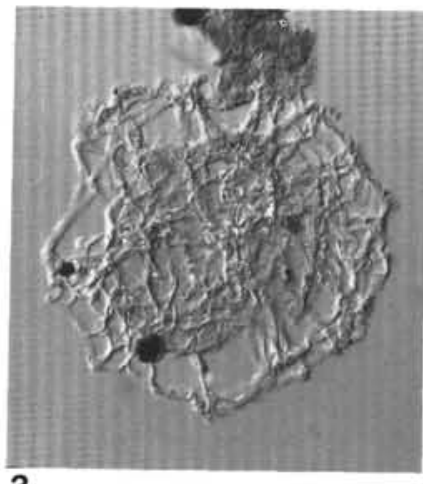

3
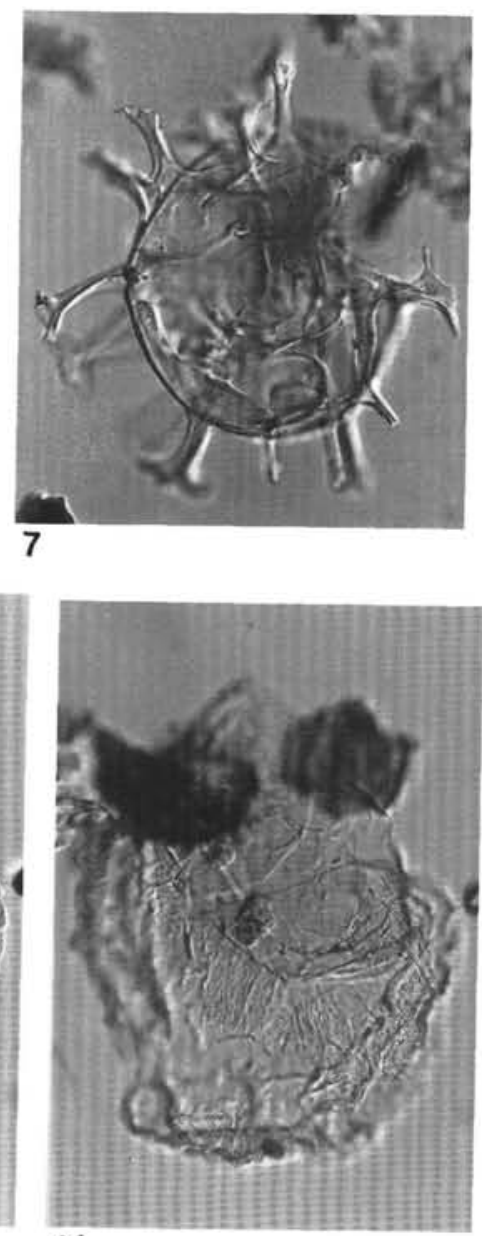

11

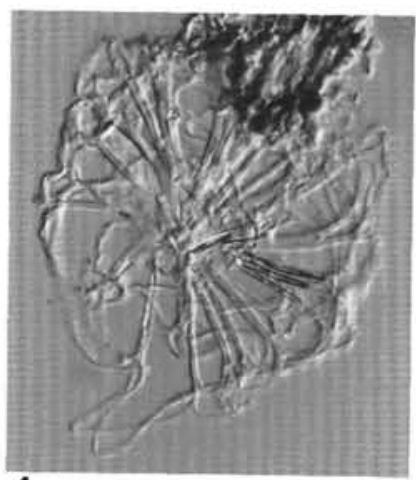

4

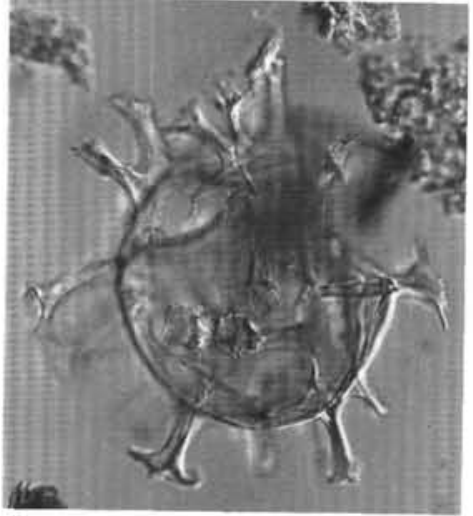

8

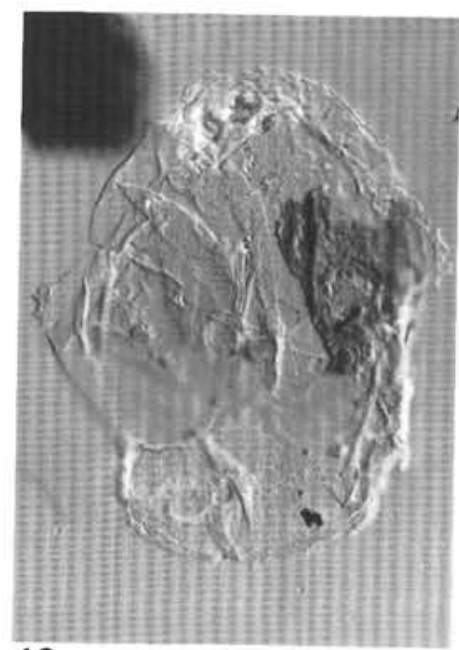

12

Plate 4. (All figures, IC). 1,2. Cannosphaeropsis? sp. 1. 1,2. Sample -43R-1, $45-48 \mathrm{~cm}$ (4) P27/4, dia. (incl. periphragm), $54 \mu \mathrm{m}$ (1, hf, 2 , lrf; note wide partially connecting distal platforms). 3,4. Nematosphaeropsis lemniscata. 3. Sample -76R-2, 134-137 cm (1) S35/0, dia. (incl. proc.), 71 $\mu$ m. 6. Spiniferites $\mu \mathrm{m}$. 6. Spiniferites sp. 1. 6. Sample $-45 \mathrm{R}-4,111-114 \mathrm{~cm}$ (4) $\mathrm{O} 44 / 0$, length (incl. proc.), $69 \mu \mathrm{m}$ (split focus). 7,8. Spiniferites pseudofurcatus. 7,8. (4) F38/0, dia. (incl. proc) $80 \mu \mathrm{m}$ 11, mf). 12. Lophocysta sp. 12 . Sample $-78 \mathrm{R}-4,74-78 \mathrm{~cm}$ (4) R5/0, length, $114 \mu \mathrm{m}$. 


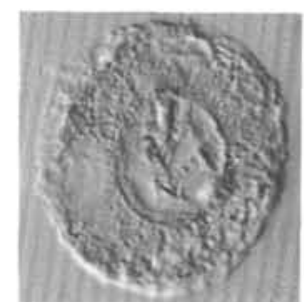

1

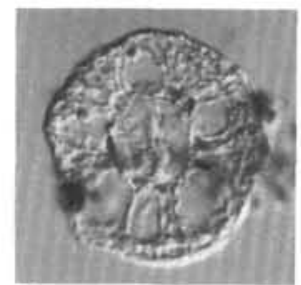

7

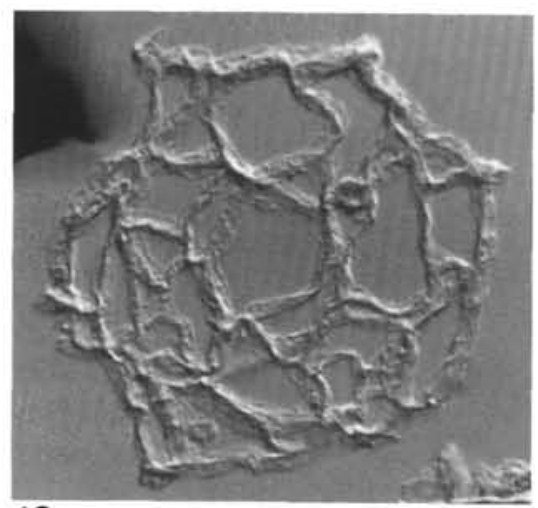

13

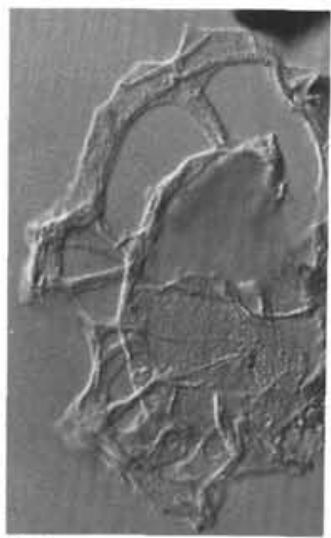

17

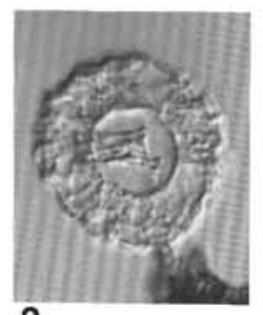

2

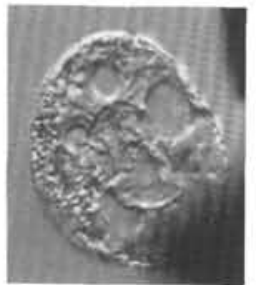

8

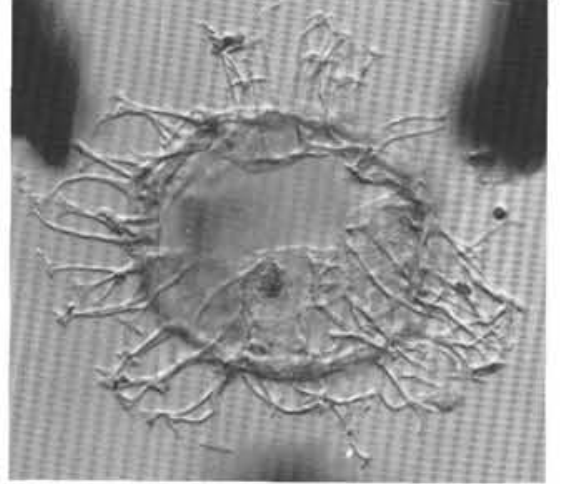

14

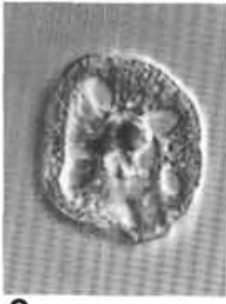

3

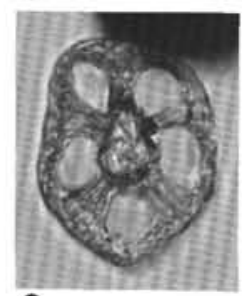

9

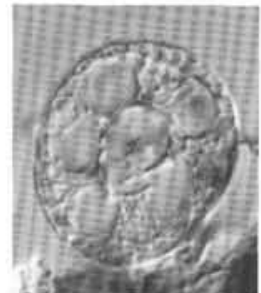

4

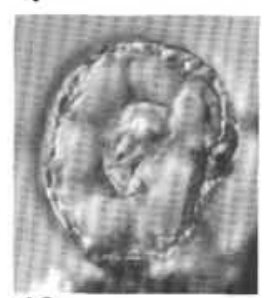

10

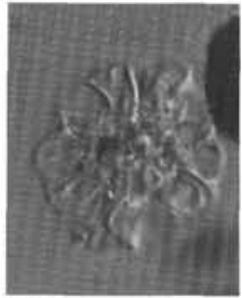

5

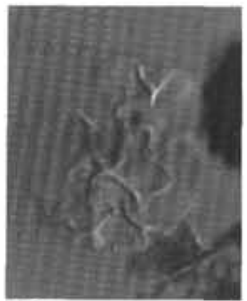

11

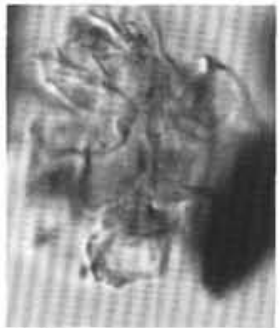

15

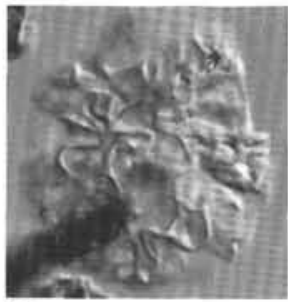

6

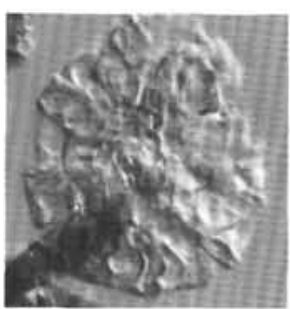

12

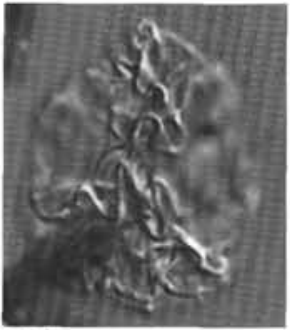

16

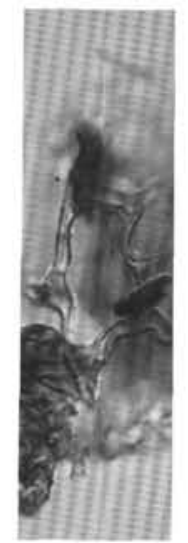

19

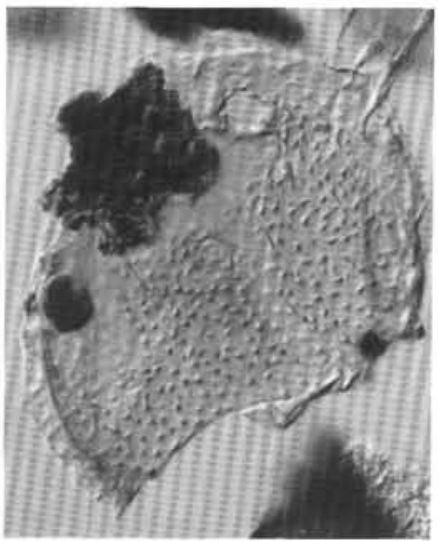

20

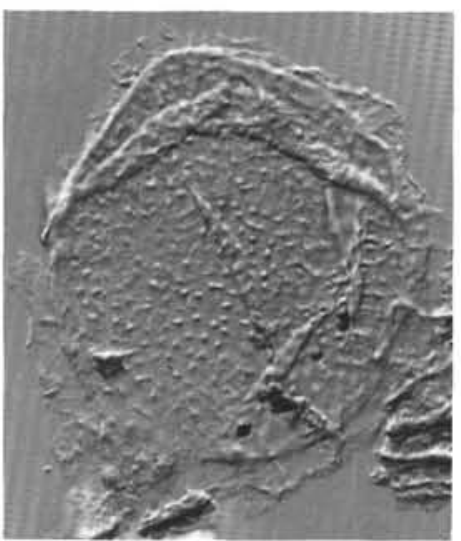

21

Plate 5. (Figs.1-8, 10-20, IC; Fig. 9, BF). 1,2. Acritarch sp. 2. 1. Sample -77R, CC, (5) P53/2, dia., $32 \mu$ m. 2. Sample -78R-4, 74-78 cm, (4) M14/ 3, dia., $23 \mu \mathrm{m}$. 3,4,7-10. Acritarch sp. 1. 3. Sample -78R-4, 74-78 cm, (4) T16/3, dia., $23 \mu \mathrm{m} .4,10$. Sample $-77 \mathrm{R}, \mathrm{CC},(5) \mathrm{F} 37 / 2$, dia., $25 \mu \mathrm{m}(4$, $\mathrm{mf}, 10$, If). 7. Sample -77R, CC, (5) K33/3, dia., $29 \mu \mathrm{m}$. 8. Sample -78R-4, 74-78 cm, (4) M22/4, dia., $29 \mu \mathrm{m}$. 9. Sample -78R-4, 74-78 cm, (4) V52/0, dia., $27 \mu \mathrm{m}$. 5,6,11,12,16. Cymatiosphaera baffinensis n. sp. (note thin central body and fairly thick crest-forming folds). 5,11. Sample -62R-1, 138-141 cm, (4) G16/3, dia., $25 \mu \mathrm{m}$ (5, hf, 11, mf). 6,12,16. Holotype, Sample -50R, CC, (4) S25/2, dia., 35 $\mu \mathrm{m}(6, \mathrm{hf}, 12$, mf, 16,1f) 15. Cymatiosphaera? sp. 15. Sample -64R, CC, (5) F25/1, dia., $36 \mu \mathrm{m}$. 13. Evittosphaerula paratabulata. 13. Sample $-72 \mathrm{R}-4,82-85 \mathrm{~cm},(4) \mathrm{S} 5 / 0$, dia., $66 \mu \mathrm{m}$. 14. Systematophora ancyrea. 14. Sample $-68 \mathrm{R}-4,117-121 \mathrm{~cm},(4) \mathrm{Q} 7 / 1$, body dia., $49 \mu \mathrm{m}$. 17. Nematosphaeropsis downii. 17. Sample -73R, CC., (5) D42/3, dia. (incl. proc.), $88 \mu \mathrm{m}$. 18,19. Nematosphaeropsis sp. A. 18,19. Sample -67R-3, 96-98 cm, (4) M25/2, 53 $\mu \mathrm{m}(18, \mathrm{mf}, 19, \mathrm{hf}) .20,21$. Cyclopsiella spiculosa n. sp. 20. Sample -69R, CC (5) U38/2, endocyst length, $69 \mu \mathrm{m}$ (hf). 21 . Holotype, Sample $-69 \mathrm{R}$, CC (5) N11/0, endocyst
length, $55 \mu \mathrm{m}$. 


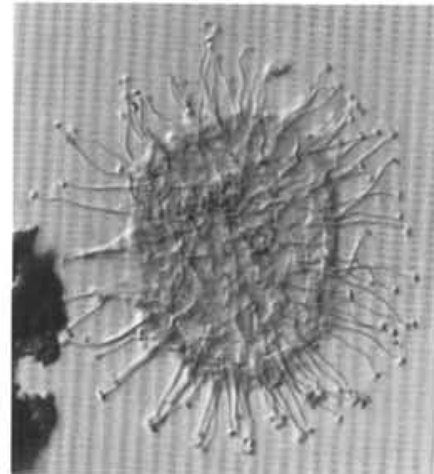

1

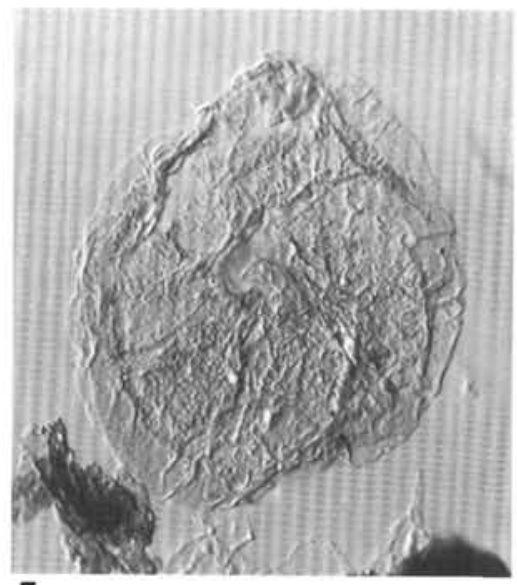

5

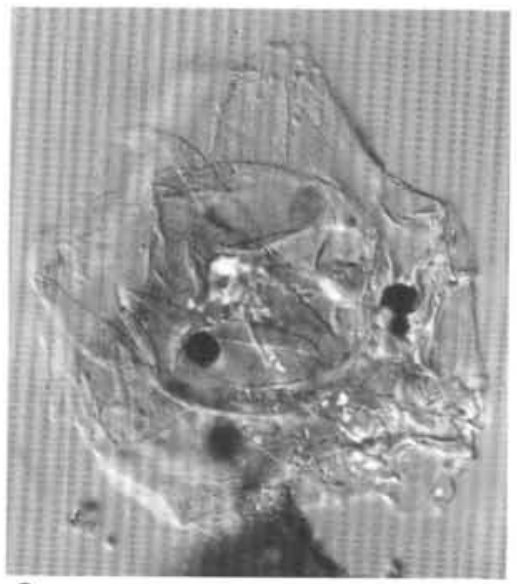

8

2
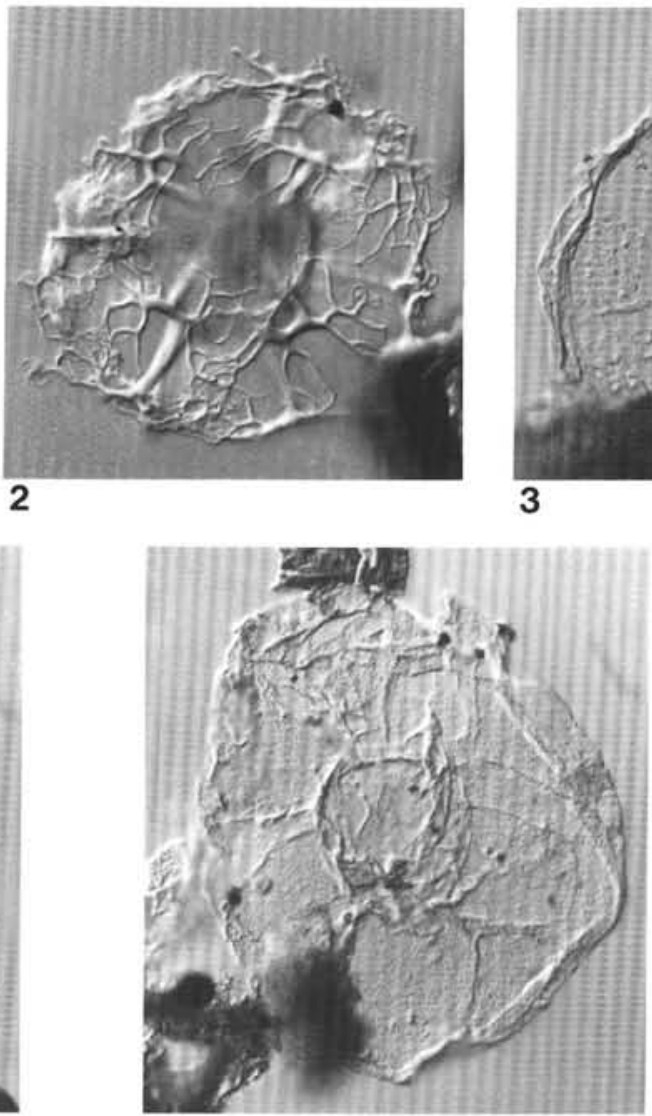

6

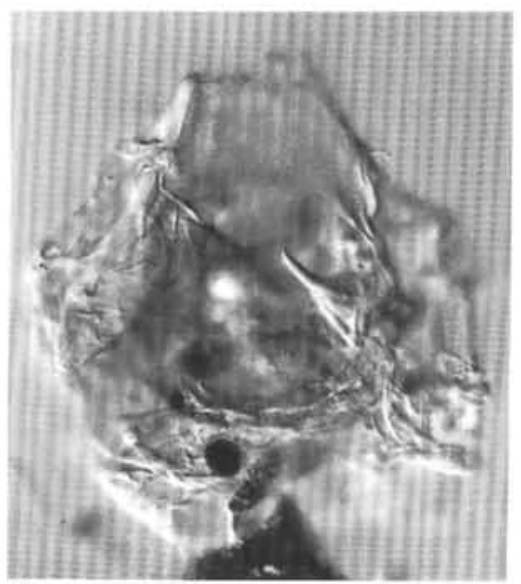

9

3
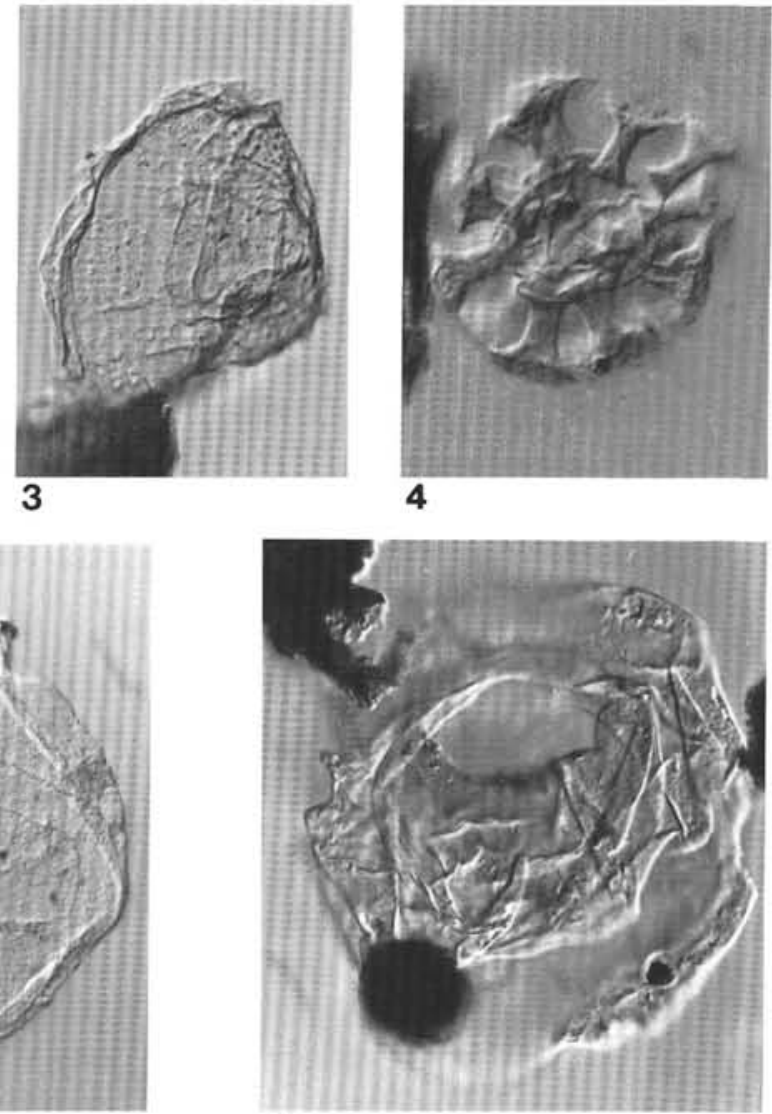

7

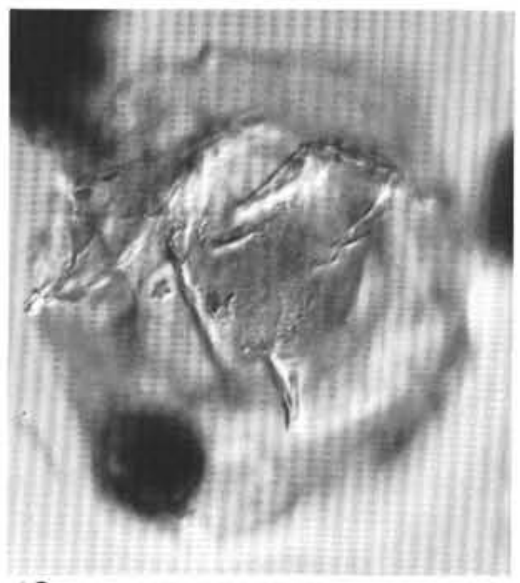

10

Plate 6. (All figures, IC). 1. Impletosphaeridium prolatum n. sp. 1. Holotype, Sample $-65 \mathrm{R}-4,94-96 \mathrm{~cm},(5) \mathrm{V} 31 / 2$, body length, $31 \mu \mathrm{m}$. 2. Reticulatosphaera actinocoronata. 2. Sample $-55 \mathrm{R}-5,17-20 \mathrm{~cm}$, (5) G9/0, dia. (incl. proc.), $55 \mu \mathrm{m}$ (hf). 3. Dinopterygium cladoides sensu Morgenroth. 3. Sample $-78 \mathrm{R}-4,74-78 \mathrm{~cm}$, (4) K17/4, dia., $49 \mu \mathrm{m}$. 4. Cordosphaeridium minimum sensu Benedek and Sarjeant. 4. Sample -78R, CC, (4) W12/3, dia. (incl. proc.), $40 \mu \mathrm{m}$. 5. Heteraulacacysta sp. A of Costa and Downie, 1979. 5. Sample $-55 \mathrm{R}-5,17-20 \mathrm{~cm},(5) \mathrm{P} 25 / 3$, dia., $80 \mu \mathrm{m}$. 6. Invertocysta tabulata. 6 . Sample $-60 \mathrm{R}-4,88-91 \mathrm{~cm},(5) \mathrm{M} 8 / 3$, dia., $96 \mu \mathrm{m}$. 7-10. Thalassiphora? sp. 1. 7,10. Sample -68R-4, 117-121 cm, (4) J43/4, dia., $89 \mu \mathrm{m}$ (dv of; 7, ds, 10 vs). 8,9. Sample -74R, CC, (5) S9/0, dia., $88 \mu \mathrm{m}$ (note spur in Fig. 9). 


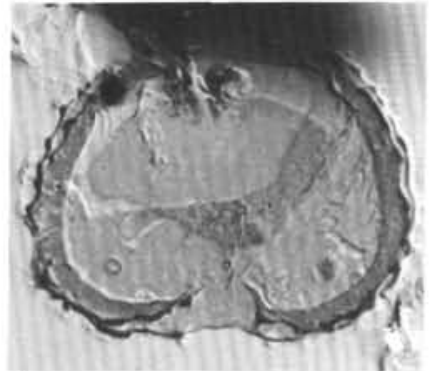

1

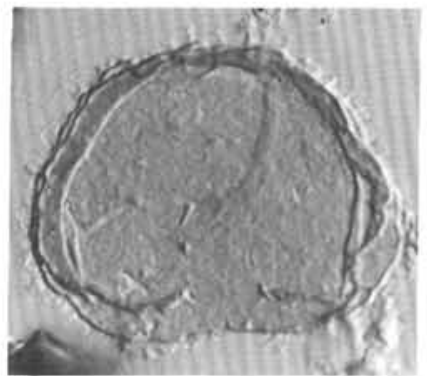

5

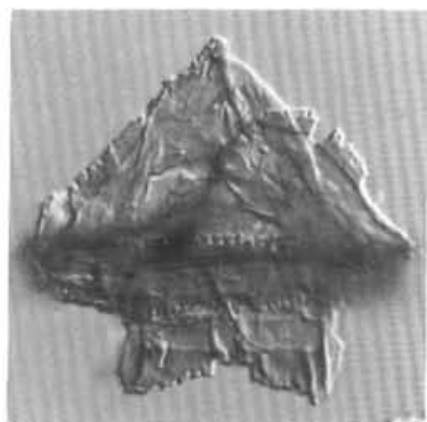

9

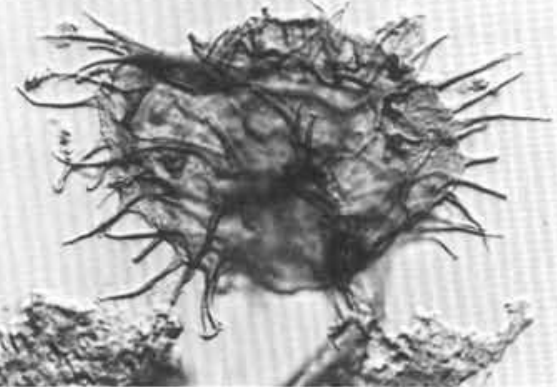

13

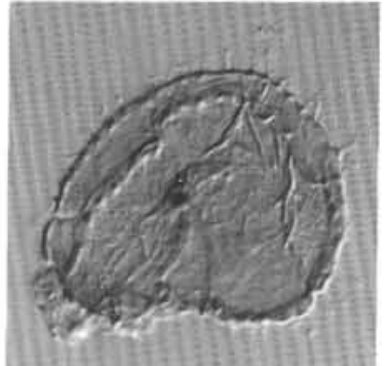

2

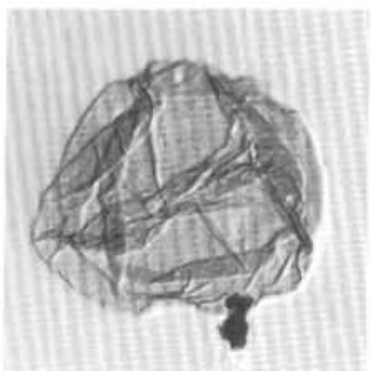

6

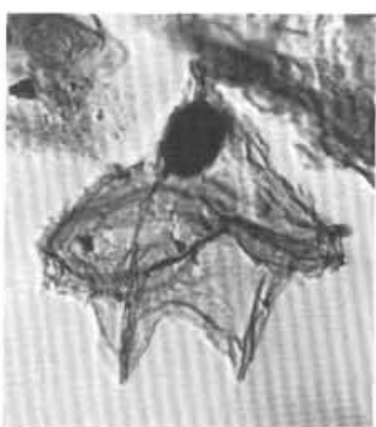

10

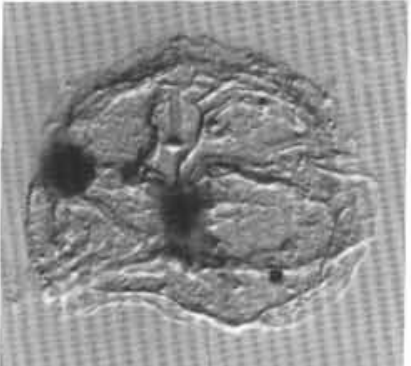

3

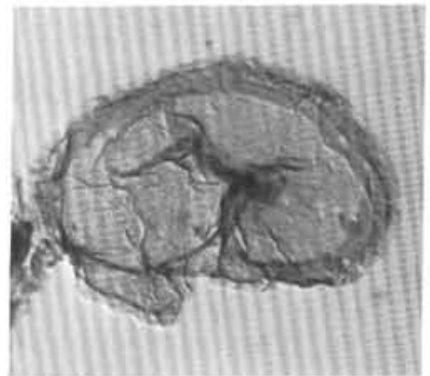

7

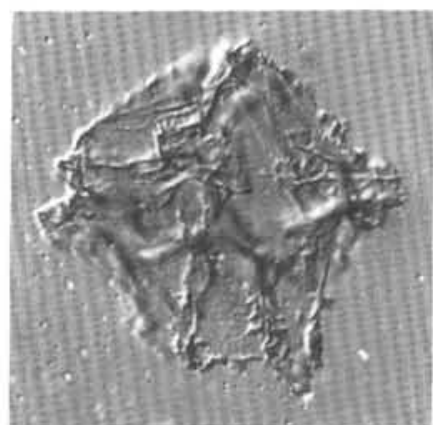

11

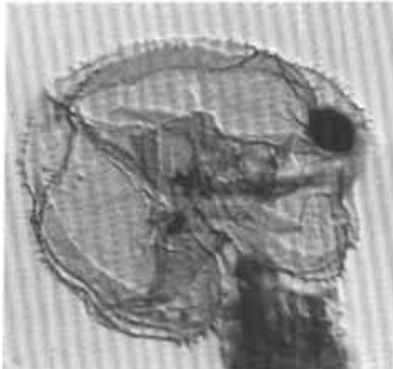

4

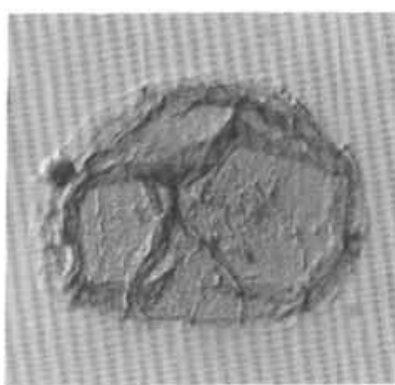

8

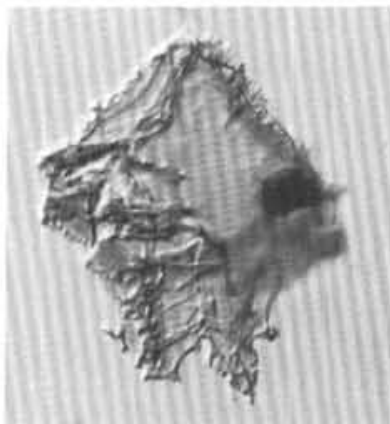

12

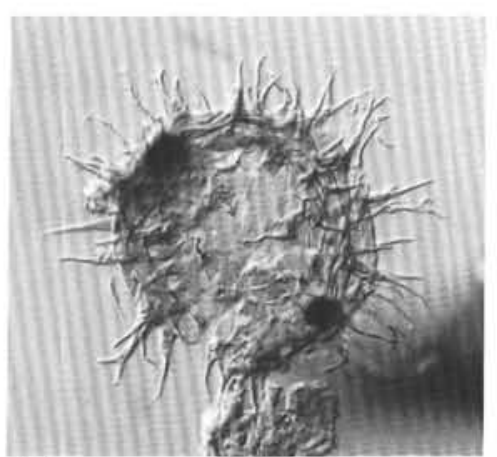

14

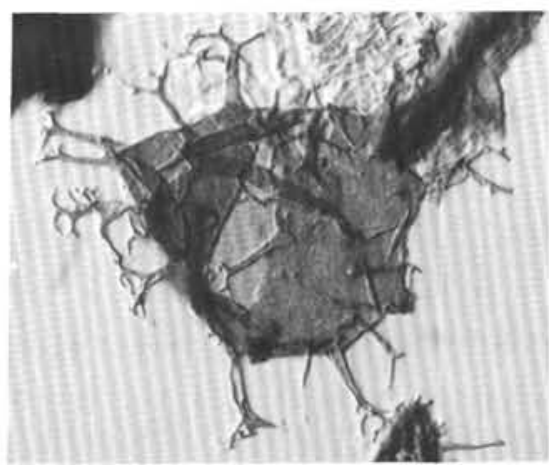

15

Plate 7. (All figures, IC). 1,2,5. Selenopemphix brevispinosa n. sp. 1. Sample -72R-4, 82-85 cm, (4) Q52/4, dia., $48 \mu \mathrm{m}$. 2. Sample -56R, CC, (4) F51/4, dia. (excl. proc.), $39 \mu \mathrm{m}$. 5. Holotype, Sample -28R-2, 8-11 cm, (5) U17/3, dia., (excl. proc.), $46 \mu \mathrm{m}$. 3,7,8. Selenopemphix sp. 1. 3. Sample $-70 \mathrm{R}-4,65-71 \mathrm{~cm}$, (4) R52/3, dia., $43 \mu \mathrm{m}$. 7. Sample -78R, CC, (4) X44/2, dia., $50 \mu \mathrm{m}$. 8. Sample $-73 \mathrm{R}-4,48-52 \mathrm{~cm},(4) \mathrm{S} 24 / 3$, dia., $46 \mu \mathrm{m}$. 4. Selenopemphix? sp. 2. 4. Sample $-75 \mathrm{R}-4,15-18 \mathrm{~cm}$, (4) D29/0, dia., $46 \mu \mathrm{m}$. 6. cf. Brigantedinium sp. 6. Sample $-78 \mathrm{R}, \mathrm{CC}, \mathrm{O} 36 / 1$, dia., $38 \mu \mathrm{m}$. 9. Cristadinium sp. 1. (dv, ds). 9. Sample $-52 \mathrm{R}-3,126-129 \mathrm{~cm}$, (5) D36/0, length, $46 \mu \mathrm{m}$. 10. Cristadinium sp. 2 (vv, vs). 10. Sample -30R, CC, (4) $\mathrm{X} 33 / 0$, length, $41 \mu \mathrm{m}$. 11. Cristadinium cristatoserratum. 11 . Sample $-28 \mathrm{R}-2,8-11 \mathrm{~cm},(5) \mathrm{O} 4 / 3$, length, $46 \mu \mathrm{m}$. 12 . Cristadinium aff. cristatoserratum. 12. Sample -26R-2, 34-37 cm, (5) U22/2, length, $43 \mu \mathrm{m}$. 13,14. Selenopemphix sp. 3. 13. Sample $-57 \mathrm{R}-4,60-65 \mathrm{~cm},(4) \mathrm{G} 49 / 1$, body dia., $55 \mu \mathrm{m}$. 14. Sample $-48 \mathrm{R}, \mathrm{CC}$, (5) T55/3, body dia., $50 \mu \mathrm{m}$. 15. Xandarodinium sp. A. 15 . Sample $-78 \mathrm{R}, \mathrm{CC},(4) \mathrm{H} 8 / 0$, body dia. $53 \mu \mathrm{m}$. 


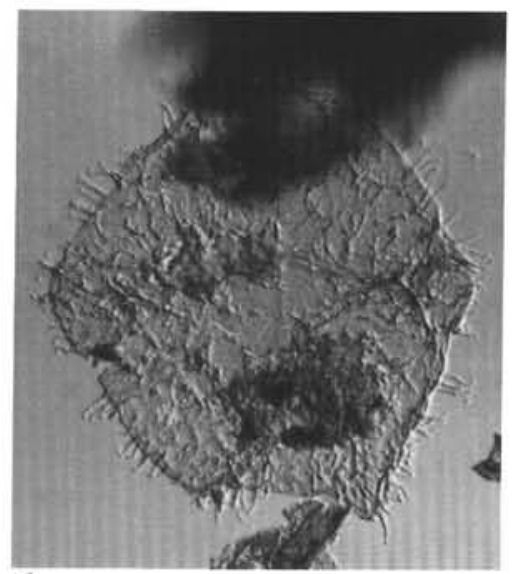

1

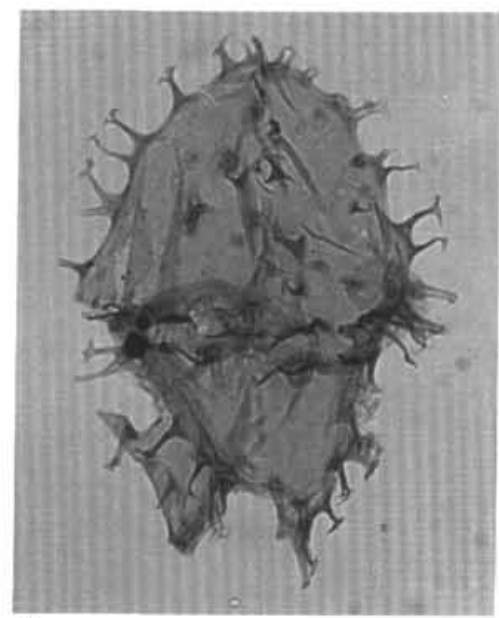

4

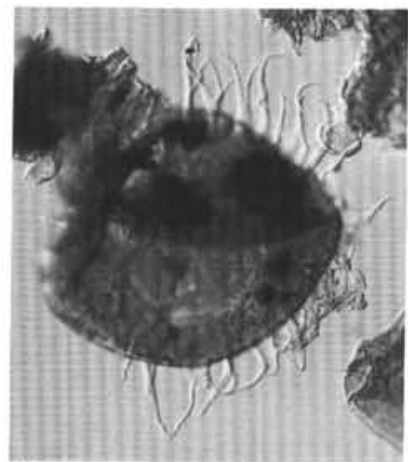

7

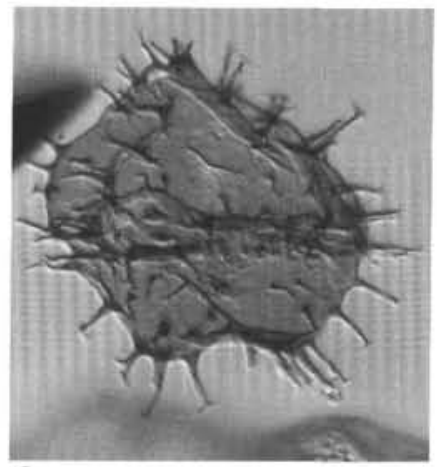

8

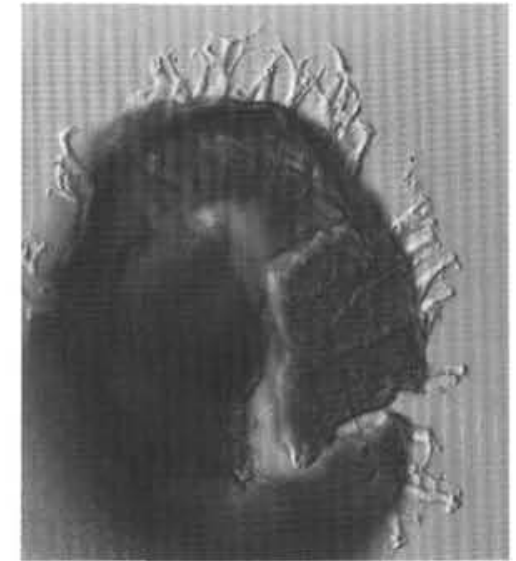

2

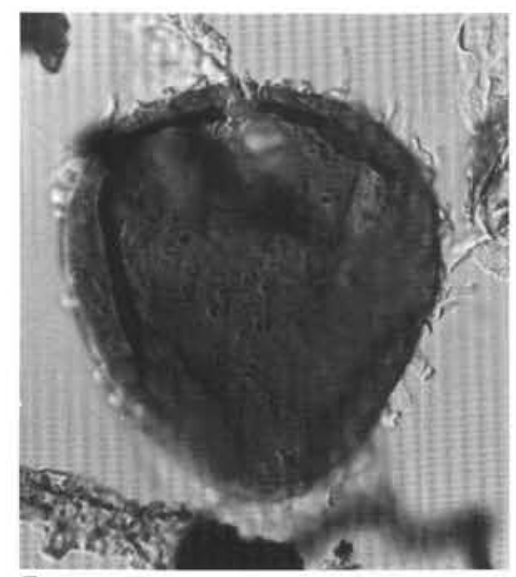

\section{5}

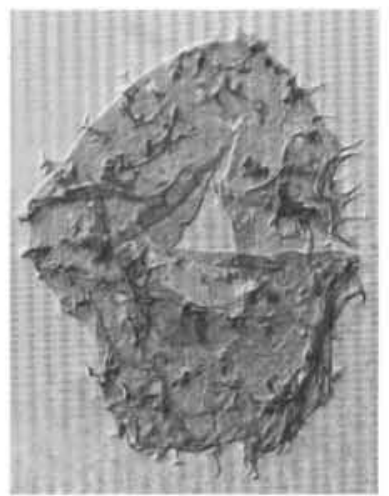

9

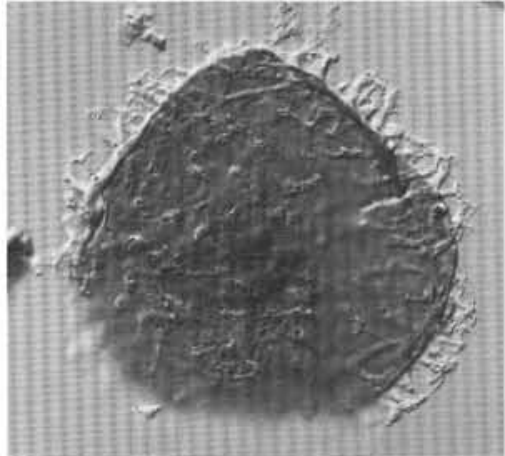

3

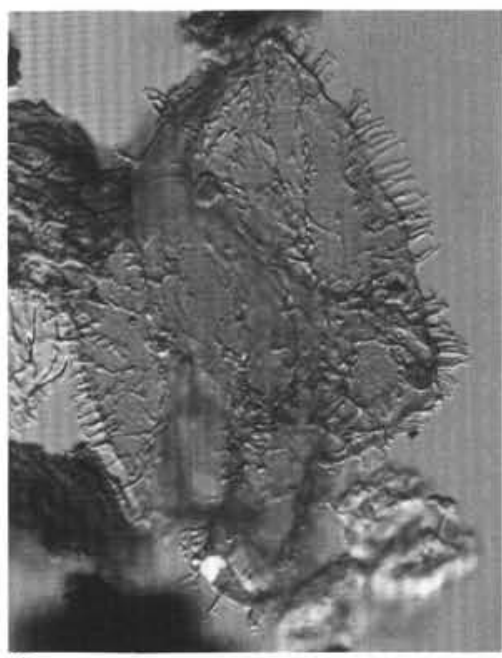

6

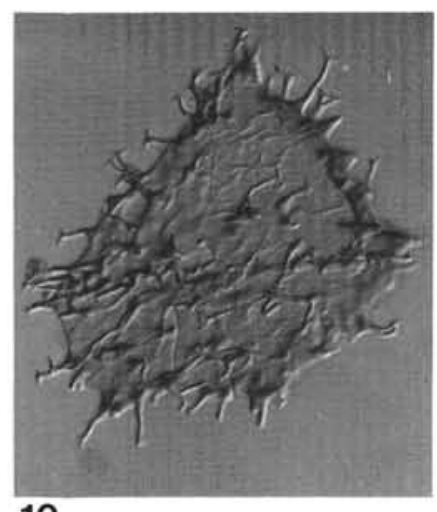

10

Plate 8. (Figs. 1-3, 5-10, IC; Fig. 4, BF). 1. Trinovantedinium sp. B. 1. Sample $-45 \mathrm{R}-4,111-114 \mathrm{~cm}$, (4) D24/0, length, $91 \mu \mathrm{m}$. 2,3. Sumatradinium sp. A (processes distally branched). 2. Sample $-40 \mathrm{R}-4,28-33 \mathrm{~cm},(5) \mathrm{M} 9 / 0$, body dia., $86 \mu \mathrm{m}$. 3. Sample $-73 \mathrm{R}$, CC, (5) W46/1, body dia., $49 \mu \mathrm{m}$. 4,8-10. Trinovantedinium sp. A. 4. Sample -69R, CC, (5) S5/2, length (incl. proc.), $69 \mu \mathrm{m}$. 8. Sample $-48 \mathrm{R}, \mathrm{CC}$, (5) S50/4, length (incl. proc.), $54 \mu \mathrm{m}$. 9. Sample $-45 \mathrm{R}-4,111-114 \mathrm{~cm}$, (4) R6/1, length, $75 \mu \mathrm{m}$. 10. Sample $-57 \mathrm{R}-4,60-65 \mathrm{~cm}$, (4) P47/3, length (excl. proc.), $62 \mu \mathrm{m}$. 5. Sumatradinium sp. of Duffield and Stein, 1986 (processes unbranched, distally rounded). 5. Sample -62R-1, 138-141 cm (4) R27/0, body dia., 71 $\mu \mathrm{m}$. 6. Trinovantedinium sp. C (note aligned processes). 6. Sample $-65 \mathrm{R}-4,94-96 \mathrm{~cm}$, (5) $\mathrm{H} 30 / 1$, length (excl. proc.), $106 \mu \mathrm{m}$. 7. Sumatradinium sp. B. (long tapering processes). 7. Sample -73R, CC, (5) E20/0, body dia., $66 \mu \mathrm{m}$. 


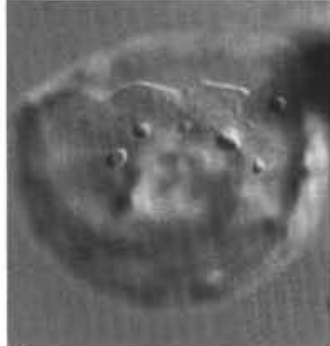

1

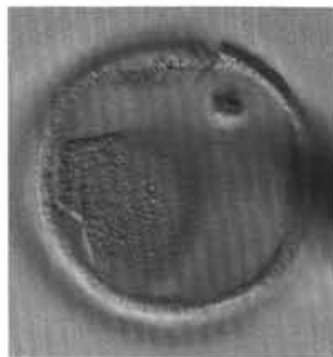

6

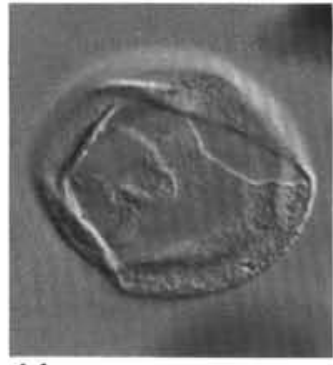

11

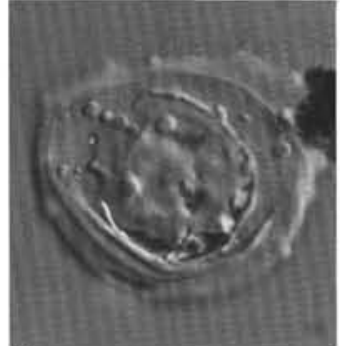

2

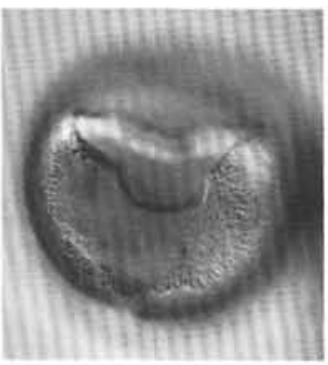

7

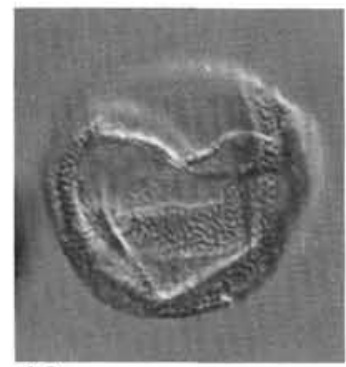

12

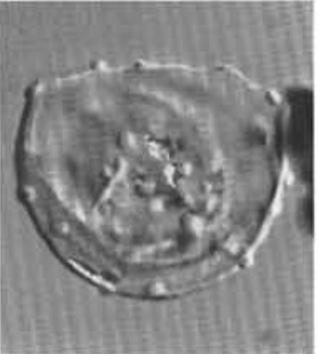

3

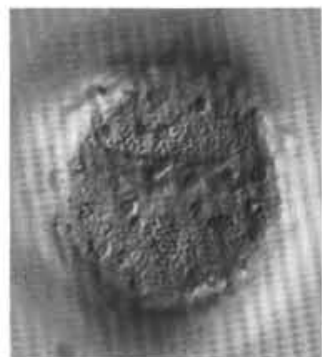

8

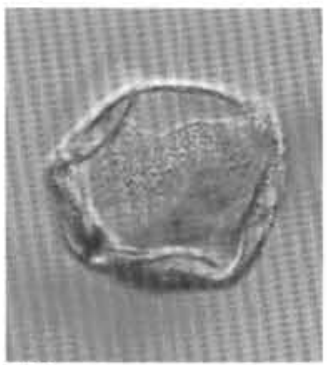

13

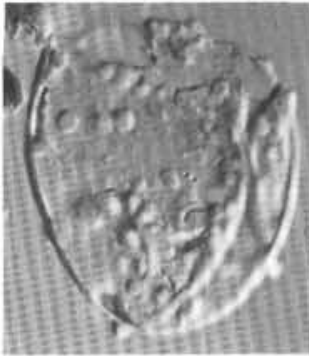

4

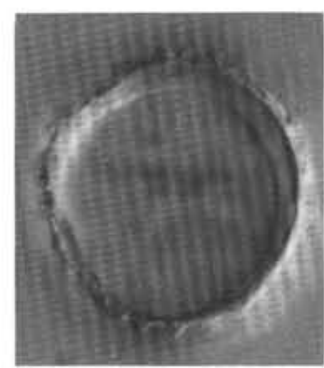

9

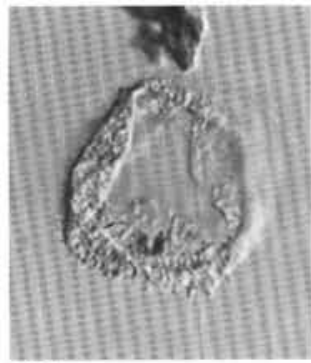

14

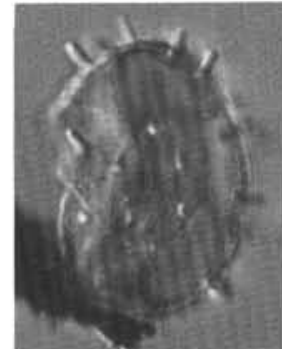

5

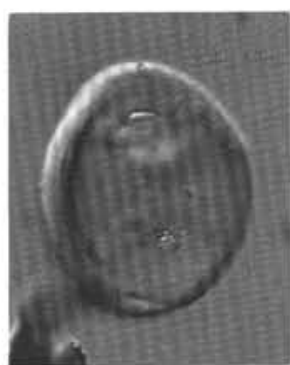

10

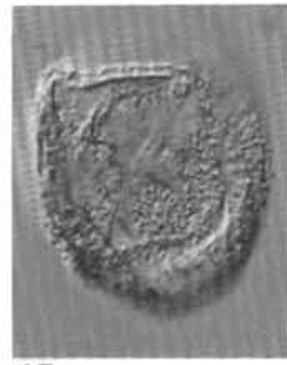

15

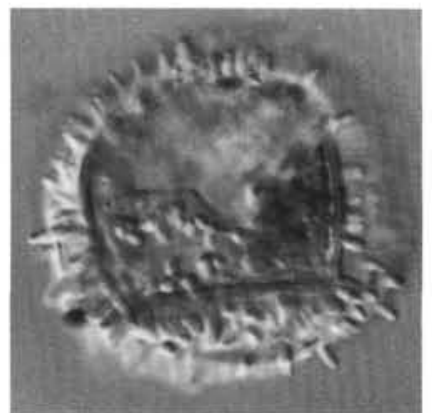

16

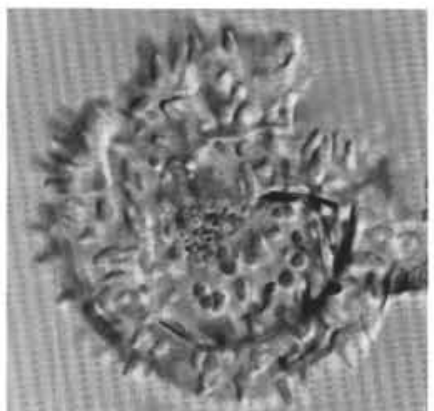

17

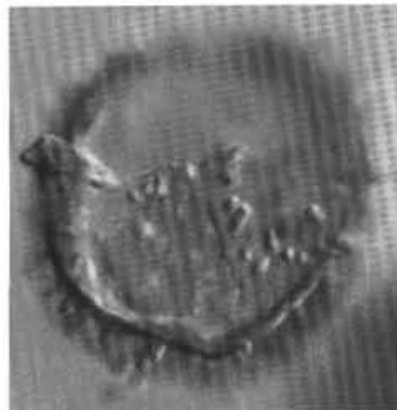

18

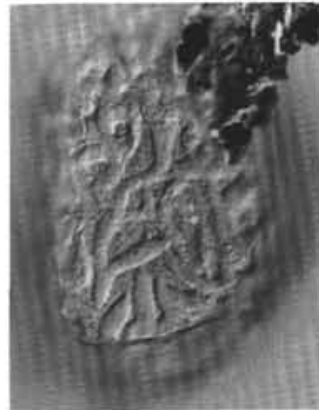

19

Plate 9. (All figures IC). 1-4. Batiacasphaera gemmata n. sp. 1-3. Holotype, Sample -78R, CC, (4) J15/3, dia., $34 \mu \mathrm{m}$ (1, lf, 2, mf-note enclosed operculum, 3, hf). 4. Sample -78R, CC, (4) O43/0, dia., $38 \mu \mathrm{m}$ (hf). 5. Operculodinium sp. 5. Sample -77R, CC, (5) J33/0, body dia., 34 $\mu \mathrm{m}$, process length, $4 \mu \mathrm{m}$. 6,7. Batiacasphaera sphaerica. 6,7. Sample -70R-4, 65-71 cm, (4) M35/1, $37 \mu \mathrm{m}(6$, hf-note enclosed operculum, 7, lf showing archeopyle). 8,9. Operculodinium vacuolatum n. sp. 8,9. Holotype, Sample $-40 \mathrm{R}-4,28-33 \mathrm{~cm}$, (5) W5/0, dia., $34 \mu \mathrm{m}$ (vv of, 8 , vs, 9, mf). 10 . Leiosphaeridia sp. 10. Sample -24R, CC, (5) R44/2, dia., $31 \mu \mathrm{m}$. 11-13. Batiacasphaera micropapillata complex. 11. Sample -75R-4, 15-18 cm, (4) $\mathrm{W} 19 / 2,34 \mu \mathrm{m}$ (lateral view, hf showing enclosed operculum). 12. Sample -72R-4, 82-85 cm, (4) H38/2, dia., $33 \mu \mathrm{m}$ (subapical view) 13 . Sample -30R, CC, (4) L42/0, dia., $29 \mu \mathrm{m}$ (subantapical view of subapical surface). 14. Batiacasphaera? sp. 1 (apical? archeopyle, short hairs). 14. Sample -63R-6, 16-19 cm (5) J43/0, dia. (excl. proc.), $26 \mu \mathrm{m}$. 15. Habibacysta tectata. 15. Sample -57R-4, 60-65 cm, (4) H18/4, dia. 33 $\mu \mathrm{m}$ (vv, vs, note semitectate wall). 16-18. Batiacasphaera sp. cf. B. baculata. 16. Sample -76R-2, 134-137 cm, (1) D21/0, dia. (excl. proc.), $49 \mu \mathrm{m}$. 17 . Sample -76R-2, 134-137 cm, (1) M49/2, dia. (excl. proc.), $50 \mu \mathrm{m}$. 18. Sample -76R-2, 134-137 cm, (1) L18/3, dia. (excl. proc.), $47 \mu \mathrm{m} .19$. Apteodinium spiridoides. 19. Sample -74R, CC, (5) F16/0, length, $65 \mu \mathrm{m}$ (vv, vs). 


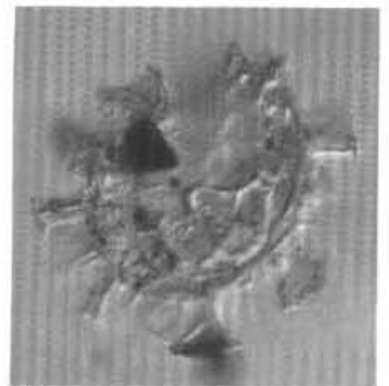

1

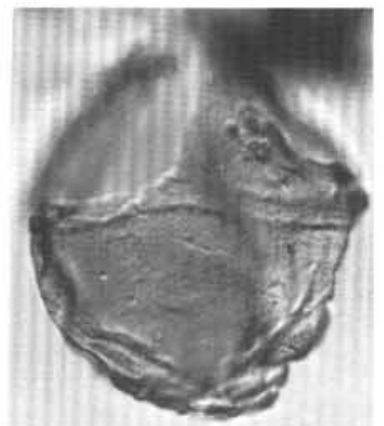

5

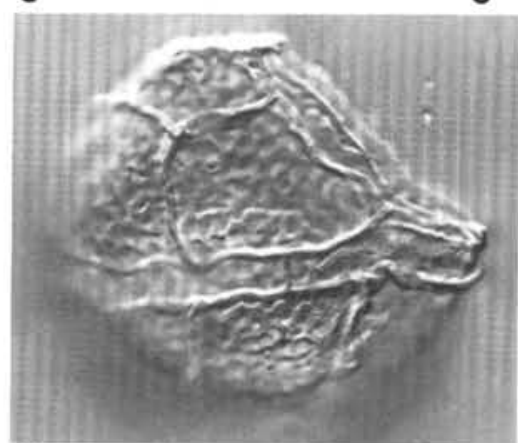

9

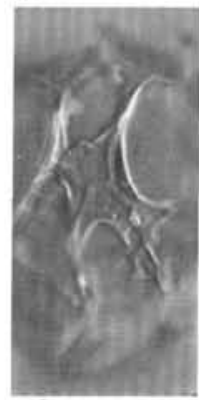

12

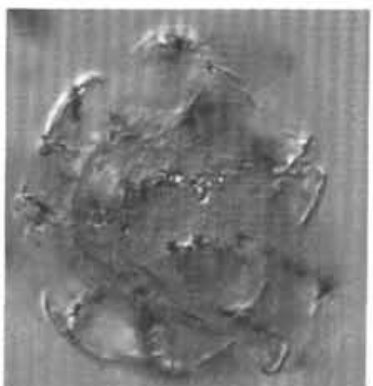

2

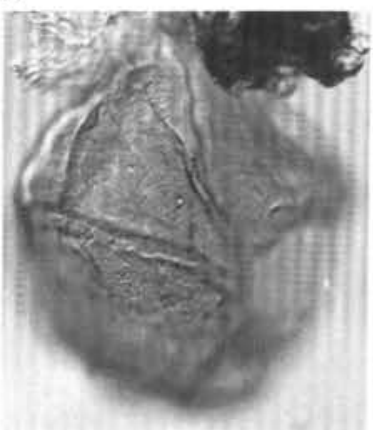

6

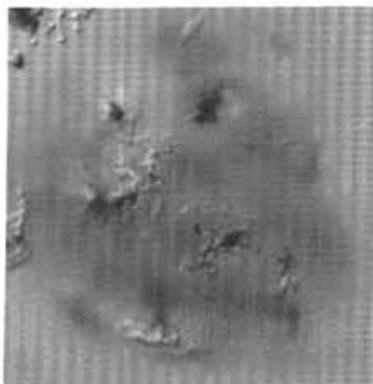

3

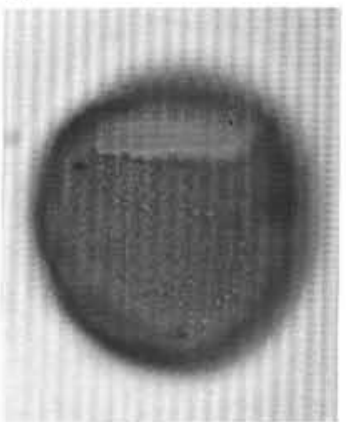

7

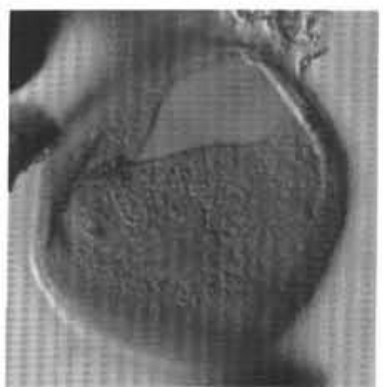

4

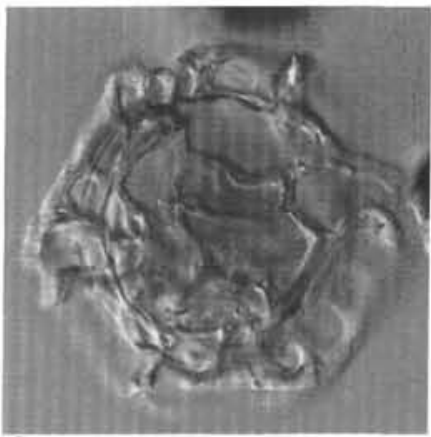

8

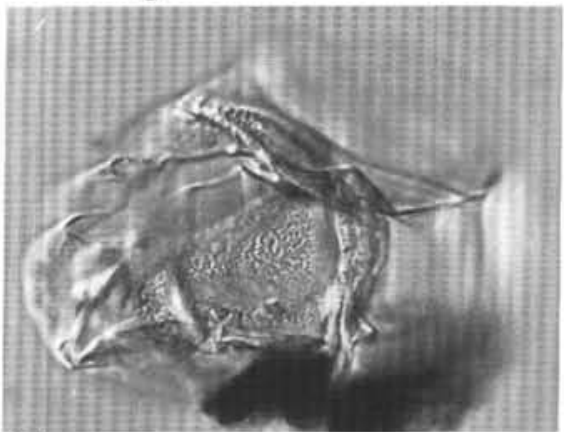

11

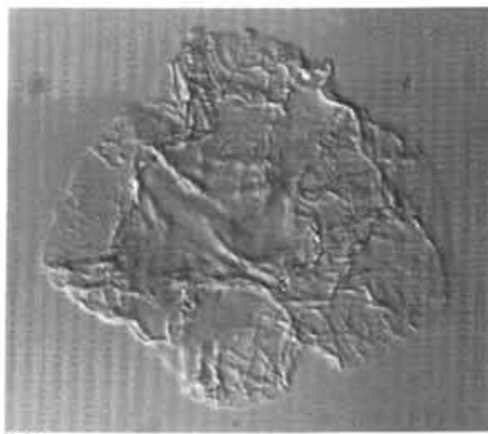

10

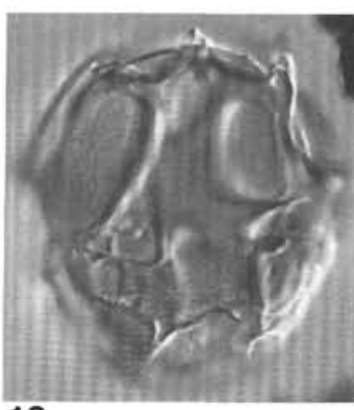

13

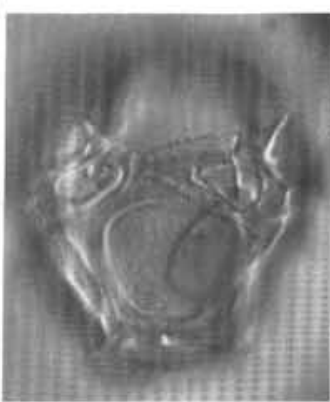

14

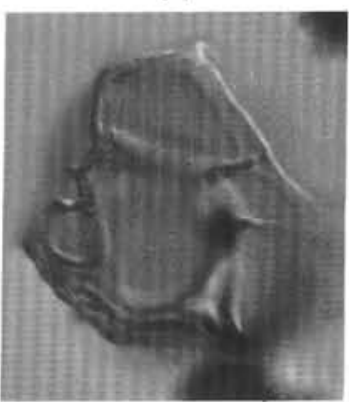

15

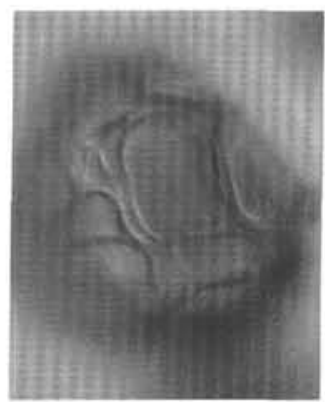

16

Plate 10. (Figs. 1-6, 8-16, IC; Fig. 7, BF). 1. Labyrinthodinium truncatum. 1. Sample -57R-4, 60-65 cm, (4) E48/2, body dia., 31 $\mu$ m. 2,3. Labyrinthodinium sp. cf. L. truncatum. 2,3. Sample -63R-6, 16-19 cm, (5) G49/4, body dia., $34 \mu \mathrm{m}$ (2, note thin distal platforms). 4. Pyxidinopsis sp. 3. 4. Sample $-62 \mathrm{R}-1,138-141 \mathrm{~cm}$, (4) R47/0, dia., $42 \mu \mathrm{m}$ (dv of ds). 5,6. Cribroperidinium tenuitabulatum. 5,6. Sample -77R, CC, (5) E14/3, dia., $69 \mu \mathrm{m}(\mathrm{vv})$. 7. Pyxidinopsis? sp. 4. 7. Sample -37R, CC, (4) F38/4, dia., $46 \mu \mathrm{m}$ (vv of ds). 8. Impagidinium aquaeductum. 8. Sample $-60 \mathrm{R}, \mathrm{CC}$, (5) F43/1, body dia., $39 \mu \mathrm{m}$ (vv of vs). 9. Impagidinium maculatum sensu Manum et al., in press. 9. Sample $-68 \mathrm{R}-4,117-121 \mathrm{~cm},(4) \mathrm{C} 31 / 3$, dia., $55 \mu \mathrm{m}$ (size ranges from 55 to $81 \mu \mathrm{m}$ ). 10. Impagidinium(?) pallidum. 10. Sample $-55 \mathrm{R}-5,17-20 \mathrm{~cm},(5) \mathrm{G} 49 / 4$, dia., $56 \mu \mathrm{m}$. 11. Pentadinium laticinctum subsp. A. 11. Sample -24R, CC, (5) M31/4, pericyst dia., $66 \mu \mathrm{m}$. 12-16. Pentadinium? sp. A. 12-14. Sample -56R, CC, (4) F45/3, pericyst dia., $46 \mu \mathrm{m}$ (vv of $12 \mathrm{vs,} \mathrm{13,} \mathrm{lrf,} \mathrm{14,} \mathrm{ds).} \mathrm{15,16.} \mathrm{Sample} \mathrm{-56R,} \mathrm{CC,} \mathrm{(4)} \mathrm{H36/3,} \mathrm{pericyst} \mathrm{dia.,} 41 \mu \mathrm{m}$ (left lateral view of $15 \mathrm{hf}, 16$, If). 


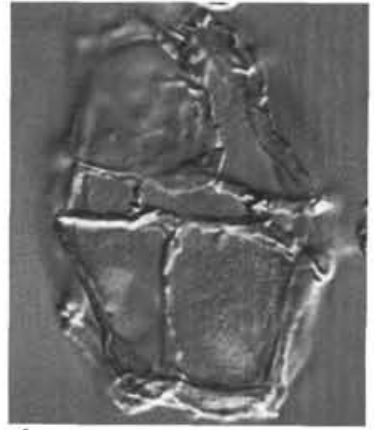

1

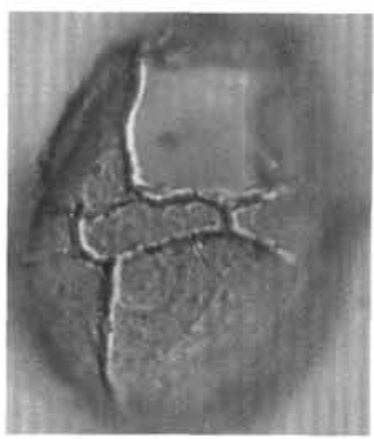

5

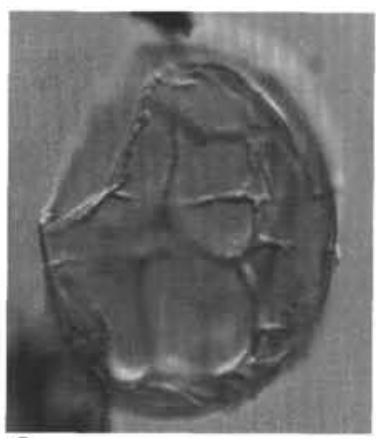

9

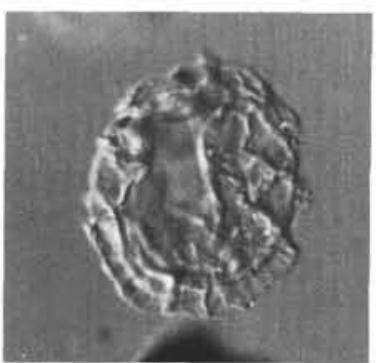

13

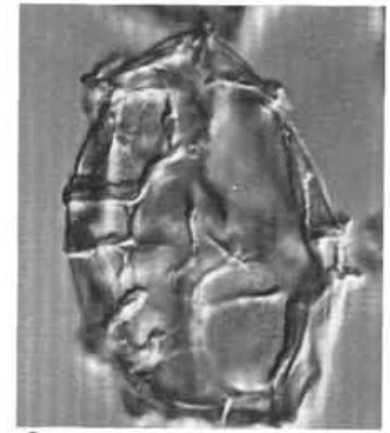

\section{2}

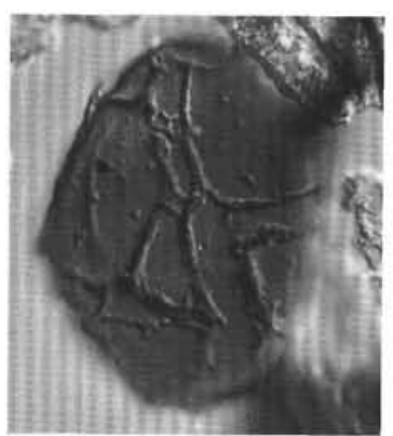

6

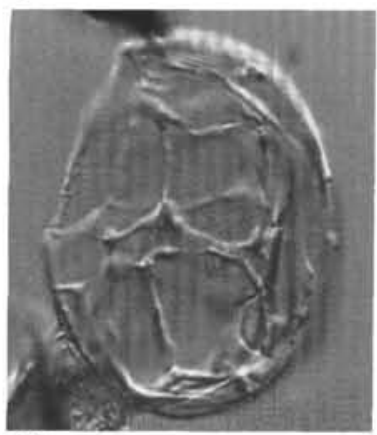

10

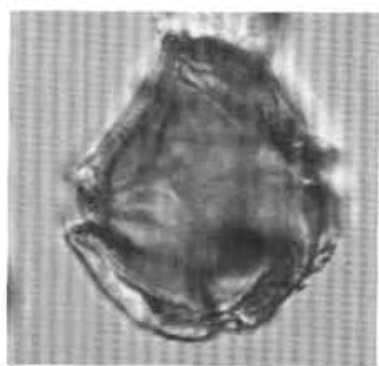

14

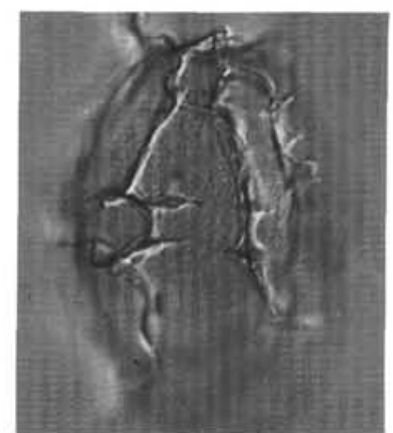

3

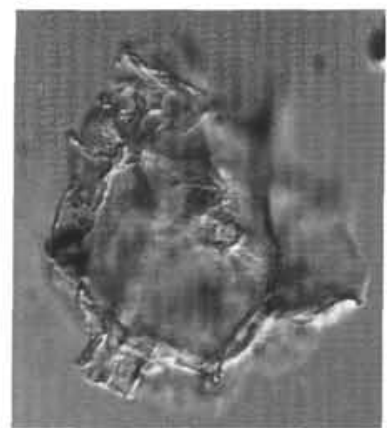

7

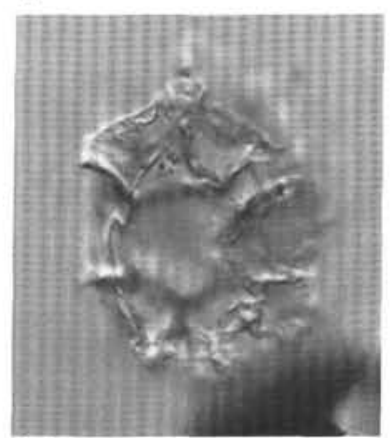

11

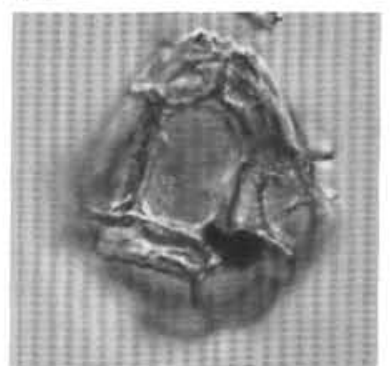

15

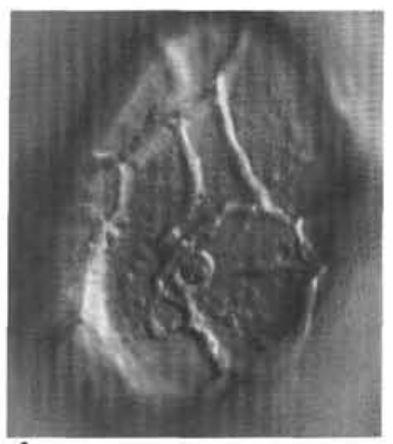

4

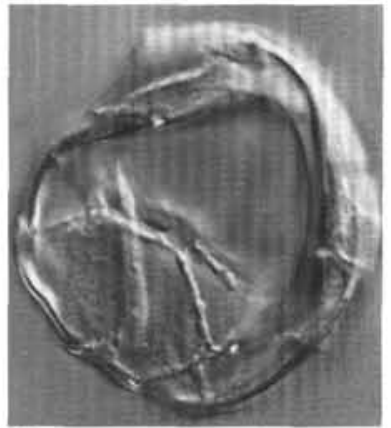

8

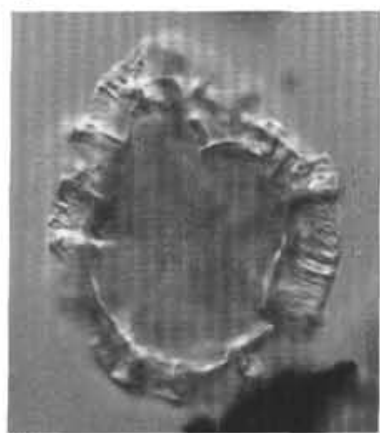

12

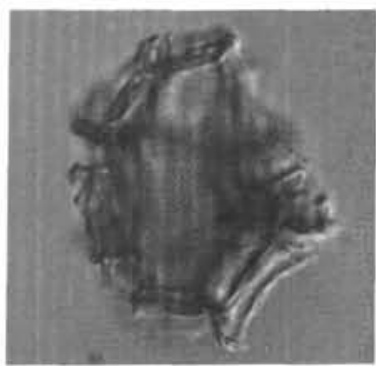

16

Plate 11. (All figures IC). 1-3. Impagidinium sp. 1. 1-2. Sample -28R-2, 8- $11 \mathrm{~cm}$, (5) Q39/0, body length, $56 \mu \mathrm{m}(1,2 \mathrm{dv}) 3$. Sample -26R-2, 34$37 \mathrm{~cm}$, (5) G17/4, body length, $51 \mu \mathrm{m}$ (vv of vs). 4-6. Impagidinium sp. 5. 4,5. Sample $-43 \mathrm{R}-1,45-48 \mathrm{~cm},(4) \mathrm{E} 50 / 2$, length, $58 \mu \mathrm{m}$ (dv of 5 , ds, 4 , vs). 6. Sample -52R-3, 126-129 cm, J20/0, length, $52 \mu \mathrm{m}$ (vv of vs). 7. Impagidinium sp. 2. 7. Sample -26R-2, 34-37 cm, (5) T8/2, dia. (incl. crests), $58 \mu \mathrm{m}$. 8. Impagidinium cf. sp. 4 (more rounded body than $I$. sp. 4). 8. Sample $-54 \mathrm{R}, \mathrm{CC},(5) \mathrm{B} 31 / 0$, dia., $49 \mu \mathrm{m}$. 9,10. Impagidinium sp. $4.9,10$. Sample -48R, CC, (5) R15/4, length, $48 \mu \mathrm{m}(9$, lf, 10, hf). 11,12. Impagidinium cf. sp. 3. 11,12. Sample -24R, CC, (5) Q34/3, length (incl. crests), $46 \mu \mathrm{m}(11, \mathrm{hf}, 12, \mathrm{mf})$. 13. Impagidinium sp. 3. 13. Sample $-24 \mathrm{R}, \mathrm{CC},(5) \mathrm{T} 46 / 0$, length (incl. crests), $34 \mu \mathrm{m}$. 14,15. Impagidinium sp. 6. 14,15. Sample -62R-1, 138-141 cm, (4) M46/4, length (incl. crests), $43 \mu \mathrm{m}$ (right lateral view, $15 \mathrm{hf}, 14, \mathrm{mf}$ ). 16. Impagidinium sp. 7 (=I. sp. 1. , Head et al, a, this volume?) 16. Sample $-24 \mathrm{R}, \mathrm{CC}$, (5) S30/1, length (incl. crests), $40 \mu \mathrm{m}$ (dv, mf). 


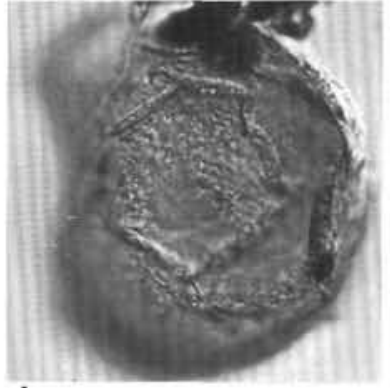

1

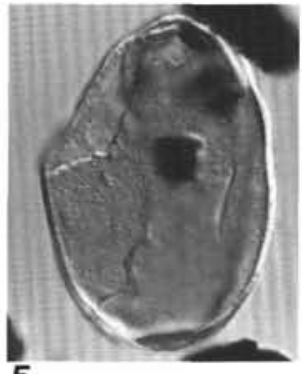

5

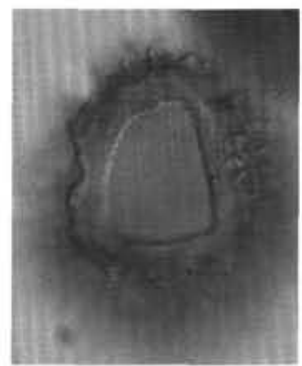

10

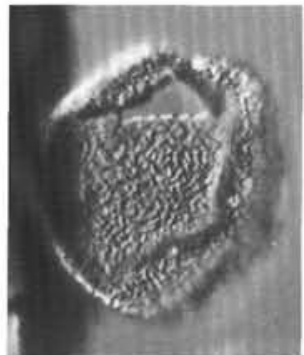

15

6

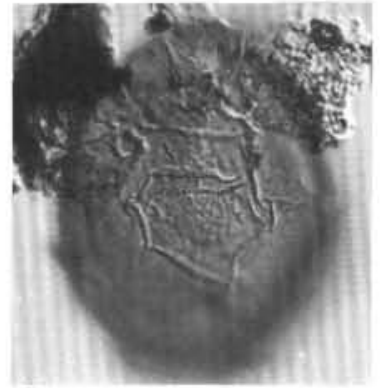

2
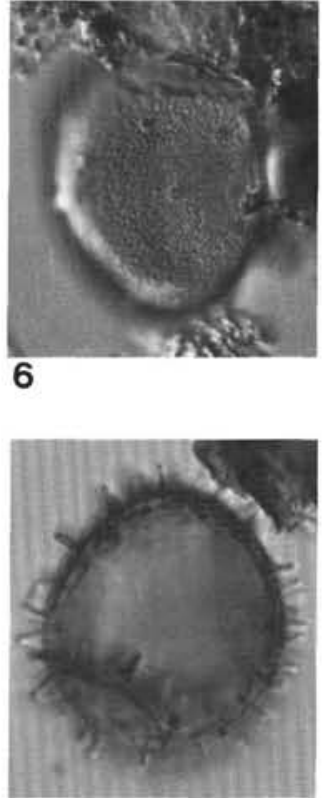

11

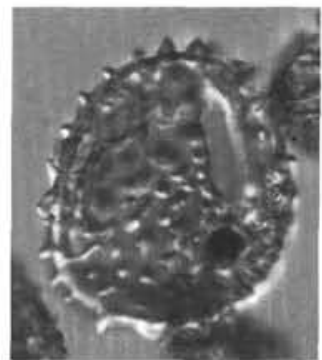

16

7

12

17

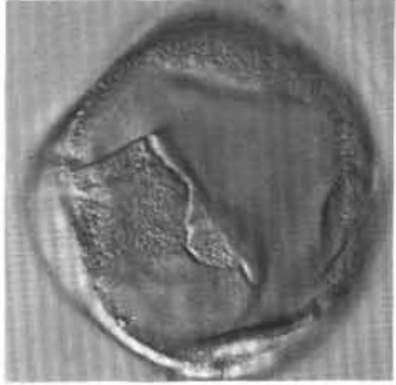

3
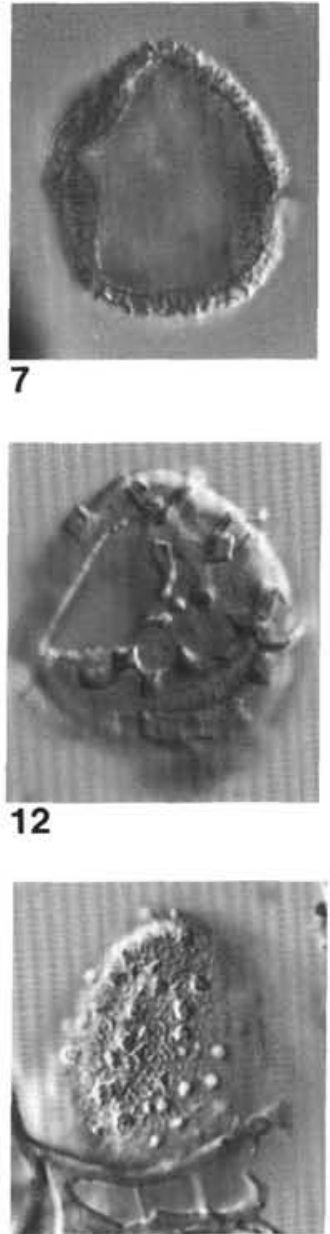

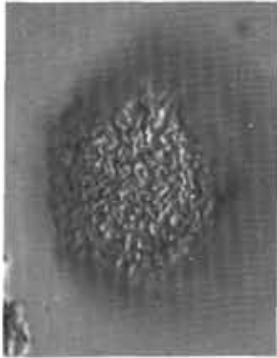

8

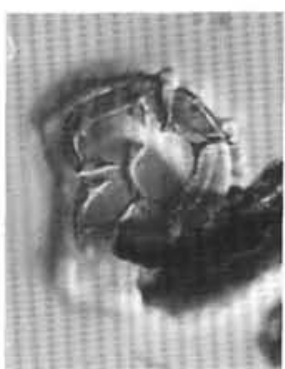

13

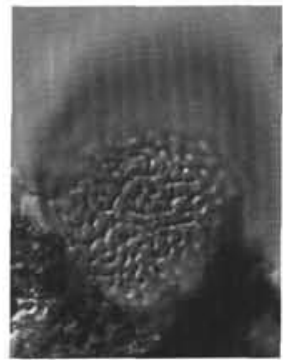

18

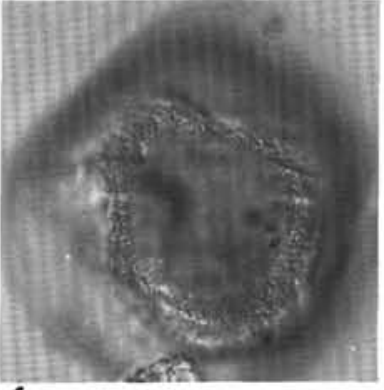

4

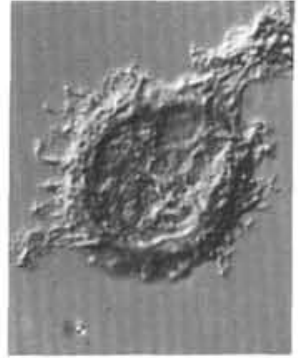

9

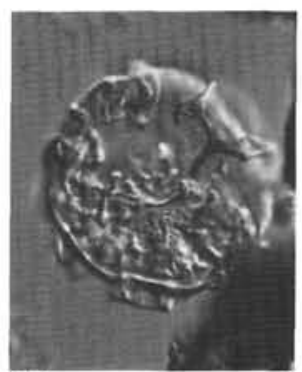

14

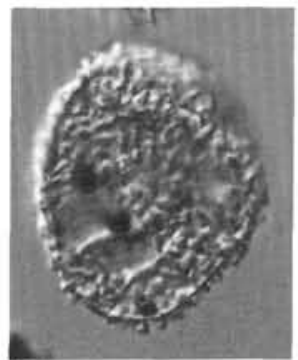

19

Plate 12. (All figures IC). 1,2. Pentadinium sp. B. 1. Sample -62R-1, 138-141 cm, (4) M46/4, length (incl. crests), $55 \mu \mathrm{m} .2$. Sample -62R-1, 138$141 \mathrm{~cm}$, (4) P36/4, length (incl. crests), $54 \mu \mathrm{m}$ (vv, vs). 3,4. Apteodinium sp. 1. 3,4. Sample -24R, CC, (5) T29/0, max. dia, $58 \mu \mathrm{m}$ (vv of 3, dorsolateral surface, and 4, vs). 5. Pyxidinopsis sp. 2. 5. Sample $-67 \mathrm{R}-3,96-98 \mathrm{~cm},(4) \mathrm{T} 12 / 0$, length, $54 \mu \mathrm{m}$. 6. Pyxidinopsis? sp. 1. 6. Sample -74R, CC, (5) J24/4, length, $35 \mu \mathrm{m}$. 7,8. Cerebrocysta? sp. 1. 7,8. Sample -70R-4, 65-71 cm, (4) J41/0, max. dia., $34 \mu \mathrm{m}$ (vv, 7, mf, 8, vs). 9. cf. Tectatodinium sp. 1 Manum, 1976. 9. Sample -72R-4, 82-85 cm, (4) S17/2, dia., (excl. processes), $25 \mu \mathrm{m}$. 10-14. Gen. et sp. indet. of Piasecki, 1980. 10, 11. Sample -43R-1, 45-48 cm, (4) R24/4, length (excl. proc.), $31 \mu \mathrm{m}$ (dv of, 10 dorsal, 11 , mf). 12. Sample -56R, CC, (4) K43/0, length (excl. proc.), $37 \mu \mathrm{m}$ (dv of ds). 13. Sample -68R-4, 117-121 cm, (4) C36/0, length (excl. proc.), $37 \mu \mathrm{m}$. 14. Sample $-48 \mathrm{R}, \mathrm{CC},(5)$ E50/0, overall length, $34 \mu \mathrm{m}$. $15-$ 19. Pyxidiella/Pyxidinopsis group. 15. Sample -69R, CC, (5) D38/1, length, $38 \mu \mathrm{m}$. 16. Sample -78R-4, 74-78 cm, (4) M30/0, length (excl. ornament), $35 \mu \mathrm{m}$. 17. Sample -67R-3, 96-98 cm, (4) P47/0, overall length, $41 \mu \mathrm{m}$. 18. Sample $-70 \mathrm{R}-4,65-71 \mathrm{~cm},(4) \mathrm{N} 47 / 0$, length, $42 \mu \mathrm{m}$. 19. Sample $-69 \mathrm{R}, \mathrm{CC},(5) \mathrm{N} 10 / 0$, length (excl. ornament), $34 \mu \mathrm{m}$. 